NOTITIE

\title{
Stekende insecten Griendtsveen 2015-2018
}

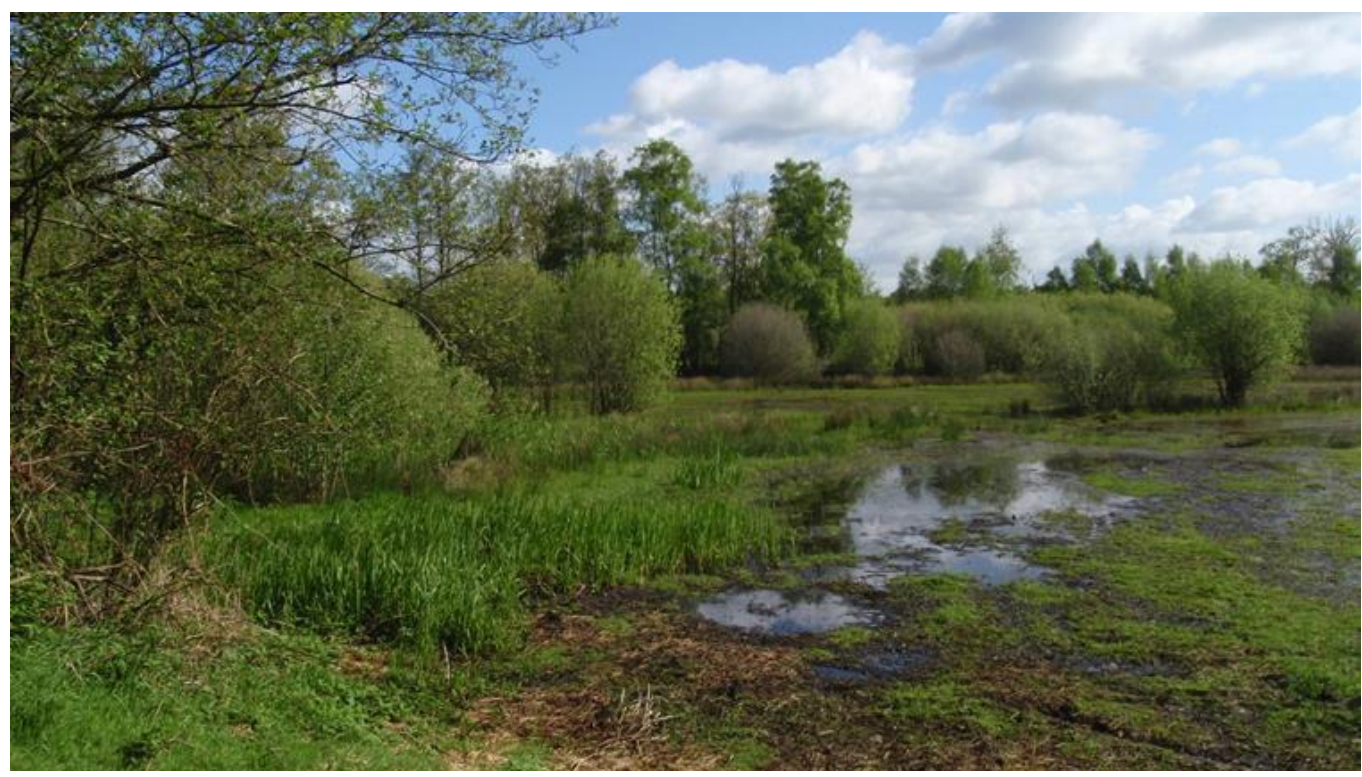

Piet F.M. Verdonschot \& Dorine T.B.M. Dekkers

Zoetwaterecosystemen, Wageningen Environmental Research

Januari 2019

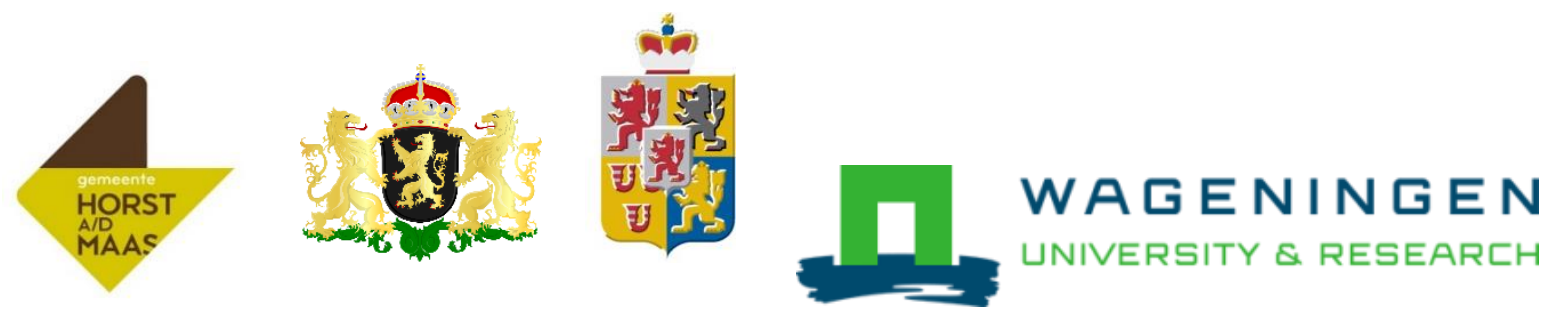




\section{Auteurs}

Verdonschot P.F.M. \& Dekkers T.B.M. (correspondentie: piet.verdonschot@wur.nl)

\section{Opdrachtgever}

Gemeente Horst a/d Maas

\section{Projectgroep}

Francois Hesen (Gemeente Horst a/d Maas), Ludy Verheggen (Provincie Limburg), Magreet Zwols, Jeroen van Leijsel (Provincie Brabant)

\section{Wijze van citeren}

Verdonschot P.F.M. \& Dekkers T.B.M. (2019). Stekende insecten Griendtsveen 2015-2018. Notitie Zoetwaterecosystemen, Wageningen Environmental Research, Wageningen UR, Wageningen. 59 pp.

\section{Trefwoorden}

Steekmuggen, knutten, hoogveen, Mariapeel, Deurnese Peel, overlast

\section{Beeldmateriaal}

T.B.M. Dekkers

ISBN: 978-94-6343-423-2

DOI: https://doi.org/10.18174/471089

Dit project is uitgevoerd in opdracht van gemeente Horst aan de Maas, Provincie Limburg, Provincie NoordBrabant.

(C) 2018 Zoetwaterecosystemen, Wageningen Environmental Research (WEnR)

- Overname, verveelvoudiging of openbaarmaking van deze uitgave is toegestaan mits met duidelijke bronvermelding.

- Overname, verveelvoudiging of openbaarmaking is niet toegestaan voor commerciële doeleinden en/of geldelijk gewin.

- Overname, verveelvoudiging of openbaarmaking is niet toegestaan voor die gedeelten van deze uitgave waarvan duidelijk is dat de auteursrechten liggen bij derden en/of zijn voorbehouden.

Wageningen Environmental Research (WEnR) aanvaardt geen aansprakelijkheid voor eventuele schade voortvloeiend uit het gebruik van de resultaten van dit onderzoek of de toepassing van de adviezen. 


\section{Inhoud}

$\begin{array}{lr}\text { Inhoud } & 1\end{array}$

$\begin{array}{lr}\text { Samenvatting } & 2\end{array}$

$1 \quad$ Inleiding en doel $\quad 3$

$\begin{array}{lll}1.1 & \text { Achtergrond } & 3\end{array}$

$\begin{array}{lll}1.2 & \text { Doelen en producten } & 3\end{array}$

2 Methoden $\quad 4$

$2.1 \quad$ Locaties en meetmomenten $\quad 4$

$\begin{array}{lll}2.1 .1 & \text { Larven } & 4\end{array}$

2.1.2 Volwassen stekende insecten $\quad 4$

2.2 Bemonsteringstechnieken en milieugegevensverzameling $\quad 5$

$\begin{array}{ll}2.2 .1 & \text { Larven } \\ 2.2 .2 & 5\end{array}$

$\begin{array}{ll}2.2 .2 \text { Volwassen stekende insecten } & 6\end{array}$

$\begin{array}{lll}2.2 .3 & \text { Milieu-parameters } & 6\end{array}$

3 Resultaten $\quad 7$

$\begin{array}{lll}3.1 & \text { Weers- en milieuomstandigheden } & 7\end{array}$

$\begin{array}{ll}3.2 & \text { Larven van steekmuggen } \\ 3.3 & 10\end{array}$

$\begin{array}{ll}3.3 \text { Volwassen stekende insecten } & 14\end{array}$

$\begin{array}{ll}\text { 3.3.1 Volwassen steekmuggen } & 14\end{array}$

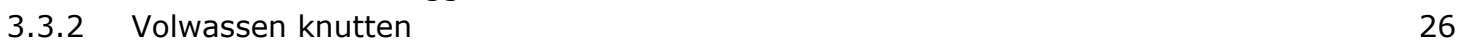

$4 \quad$ Discussie en conclusies $\quad 30$

$\begin{array}{lll}4.1 & \text { Larven van steekmuggen } & 30\end{array}$

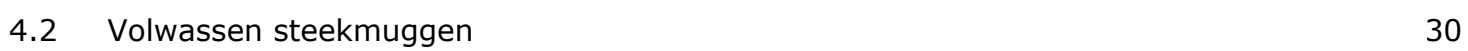

$\begin{array}{lll}4.3 & \text { Volwassen knutten } & 31\end{array}$

$\begin{array}{lll}4.4 & \text { Conclusies en aanbevelingen } & 31\end{array}$

Bijlagen 


\section{Samenvatting}

De inventarisatie van steekmuglarven leverde in 2016 vier kleinere gebiedsdelen op met hoge aantallen steekmuglarven (de zogenaamde 'hotspots'). In april-mei 2017 en 2018 zijn de larveninventarisaties herhaald. Hieruit bleek dat de larven van de moerassteekmug $A$. cinereus over het gehele gebied verspreid zijn met op twee van de vier 'hotspots' de hoogste aantallen. In de periode daarna vielen in beide jaren de meeste locaties droog.

Het jaar 2017 was een droog jaar waarbij al vroeg in het voorjaar, mogelijk zelfs in de winter, veel potentiële tijdelijke wateren droog stonden. Na een natte winter werd 2018 een nog extremer droog jaar met veel droogval in het gebied.

Het patroon van ontwikkeling van volwassen steekmuggen liet over 2017 een 'klassiek' beeld van een moerassteekmuggenpopulatie zien met hoge aantallen in het voorjaar die daarna snel uitdoven. Alleen in juni trad additioneel een kleine populatie van plantenboorsteekmuggen op. Dit beeld is een gevolg van het opdrogen van tijdelijke wateren in het voorjaar. De in totaal lagere aantallen in het gehele gebied en de beperking van deze aantallen tot de maand mei hebben ertoe geleid dat in het dorp Griendtsveen in 2017 geen overlast is ervaren. 2018 daarentegen was in de winter normaal nat wat, mogelijk in combinatie met de natheid van het gebied, leidde tot zeer hoge aantallen moerassteekmuggen. Dit waren de hoogste aantallen tot nu toe gemeten.

De verdeling van de aantallen over de jaren 2015-2018 naar zone rondom en in het dorp laat zien dat er ieder jaar een afname van de aantallen optreedt richting de dorpskern.

In de periode $2015-2018$ is het aantallen verzamelde knutten jaarlijks toegenomen. De aantallen zijn in 2018 viermaal hoger t.o.v. 2015. Dit kan samenhangen met grotere oppervlakken nattere gebiedsdelen, nattere weilanden aan de zuidzijde, in het dorp en aan de westzijde. Ondanks de aanpak van de knutten hotspot, wat lokaal voor een aanzienlijke vermindering heeft gezorgd, zet de ontwikkeling van de knutten in andere gebiedsdelen (nog) door.

De adviezen voor maatregelen om de 'hotspots' aan te pakken zijn in 2017 in gang gezet en ten dele in 2018 uitgevoerd. De resultaten zijn nog niet zichtbaar in de voorjaarsmetingen van 2018 omdat op dat moment de maatregelen nog moesten worden geïmplementeerd. 


\section{$1 \quad$ Inleiding en doel}

\section{$1.1 \quad$ Achtergrond}

In opdracht van de Provincie Limburg en de Gemeente Horst a/d Maas is in de periode 2015-208 door Wageningen Environmental Research (WEnR) onderzoek naar stekende insecten uitgevoerd. Hieruit is gebleken dat de door de bewoners van Griendtsveen gesignaleerde overlast van steekmuggen reëel is. De overlast wordt veroorzaakt door moerassteekmuggen (voornamelijk de soort Aedes cinereus), die afkomstig zijn uit de Mariapeel, de Deurnsche Peel, het Kanaalbos en het Grauwveen. De overlast veroorzakende soort ontwikkelt zich in langdurig water bevattende tijdelijke wateren. De steekmuggen verspreiden zich na het uitvliegen over de omgeving, onder andere in de richting van het dorp. De geleidelijk gewijzigde hydrologische omstandigheden in de natuur-/moerasgebieden die het dorp omringen, kunnen bijgedragen hebben aan een toename van moerassteekmuggen in het dorp. De onderzoeksresultaten geven tevens aan dat de voorgenomen LIFE+ maatregelen Mariapeel kunnen bijdragen aan een vermindering van de aantallen moerassteekmuggen, mits deze bij de uitvoering ook leiden tot vermindering van het oppervlak aan langdurig tijdelijke wateren. Daarom is door de adviescommissie Mariapeel het besluit genomen om de nog uit te voeren maatregelen van het LIFE+ project in de Mariapeel zo uit te voeren dat de overlast door moerassteekmuggen wordt teruggedrongen. Om de uit te voeren maatregelen ook beperkend voor steekmuggen te laten zijn voor de periode 20162018 zijn de volgende vragen gesteld:

1. Waar liggen in een zone van 2 kilometer rond het dorp Griendtsveen de broedplaatsen van de overlast veroorzakende moerassteekmuggen?

2. Welke sturingsmechanismen in de waterhuishouding om de ontwikkeling van broedplaatsen in de moerasgebieden gedurende de looptijd van het LIFE+ project tegen te gaan zijn er?

3. Kunnen de direct overlast veroorzakende gebiedsdelen (zgn. 'hotspots') op korte termijn worden aangepakt?

4. Hoe ontwikkelen de moerassteekmuggen zich in en rondom het dorp Griendtsveen gedurende de uitvoering van het LIFE+ project (2016-2018) en in de jaren daarna (2019-2021)?

\subsection{Doelen en producten}

Het doel van het project is het terugdringen van de steekmuggenoverlast in Griendtsveen door:

Het in het maatregelenpakket van LIFE+ in de Mariapeel opnemen van een aangepast peilbeheer om de ontwikkeling van langdurig tijdelijke wateren tegen te gaan en de isolatie van langdurig tijdelijke wateren op te heffen. Hiervoor dienen de langdurig tijdelijke wateren die functioneren als broedplaats voor moerassteekmuggen te worden gekarteerd en dient de gebiedshydrologie en -morfologie te worden vastgelegd om doelgerichte maatregelen te kunnen formuleren.

- Het instellen van een monitoringsmeetnet om de overlast van stekende insecten in en rondom het dorp Griendtsveen te kunnen volgen in de tijd.

- $\quad$ Eventueel de verbindingszones waarlangs moerassteekmuggen zouden kunnen migreren van het natuurgebied naar het dorp zo in te richten dat deze dienen als barrières voor stekende insecten. 


\section{Methoden}

\section{$2.1 \quad$ Locaties en meetmomenten}

\subsubsection{Larven}

Het onderzoek naar broedplaatsen van moerassteekmuggen is uitgevoerd in de Deurnsche Peel, Mariapeel, het Kanaalbos en Grauwveen in een straal van 1,5 - 2 km rond het dorp Griendtsveen. In 2016-2018 zijn de langdurig tijdelijke wateren steekproefsgewijs in beeld gebracht om een beeld te verkrijgen van de habitat van vooral de moerassteekmug Aedes cinereus.

1) In de periode april - mei 2018 zijn broedplaatsen die in 2016 en 2017 waren bezocht wederom bemonsterd. De aanwezigheid en dichtheid van larven van moerassteekmuggen is met behulp van de dip-techniek ( $95 \mathrm{~cm}^{2}$ ), bemonsterd (zie paragraaf 2.3). Op locaties waar larven werden aangetroffen zijn een aantal milieufactoren gemeten: breedte, diepte, vegetatietype/-structuur. In totaal zijn 161 locaties verspreid over het gebied bezocht en 104 bemonsterd, de overige locaties waren in het voorjaar al opgedroogd (Figuur 2.1).

2) Op een aantal locaties is in 2018 de ontwikkeling van de populaties van larven van steekmuggen gevolgd in de tijd. Voor deze tijdreeks is van april tot eind september maandelijks het aantal steekmuglarven bepaald.

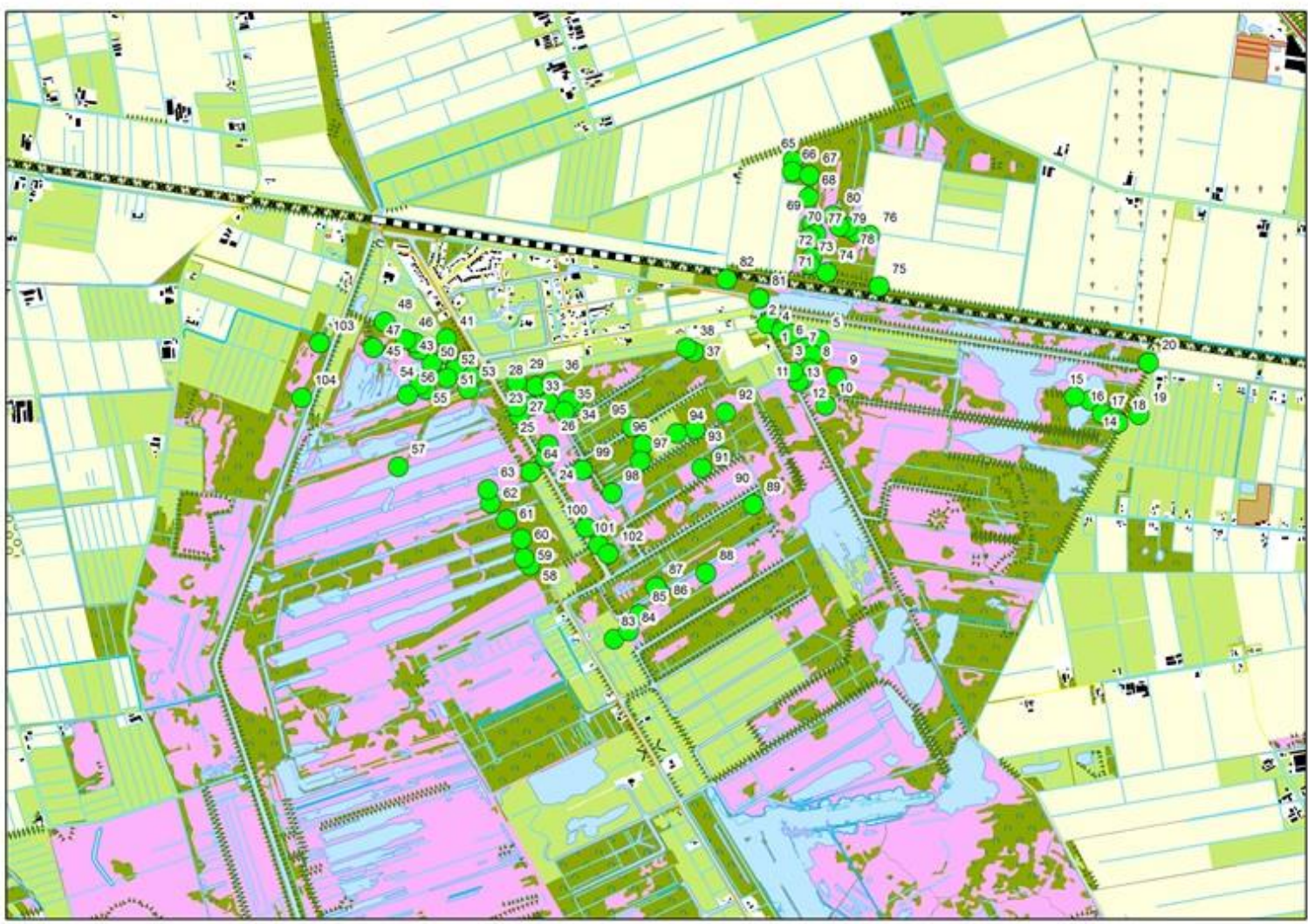

Figuur 2.1: Kaart van het onderzoeksgebied met bemonsteringslocaties voor de muggenlarven in 2018.

\subsubsection{Volwassen stekende insecten}

In en rondom Griendtsveen zijn de aanwezigheid en dichtheid van volwassen steekmuggen en knutten gemeten. In totaal zijn 18 meetlocaties ingericht (Figuur 2.2, Bijlage 1). De locaties komen overeen met de locaties die ook in 2015, 2016 en 2017 zijn gemeten. De locaties zijn verdeeld over vijf zones (Tabel 2.1):

- $\quad$ Moerasgebied en overgangszone oost: 1, 2, 3, 18

- $\quad$ Moerasgebied en overgangszone zuid: 4, 5, 7, 8

- $\quad$ Moerasgebied en overgangszone west: $10,11,12,13$

- $\quad$ Dorp: $9,14,15,17$

- Dorp oost: 6, 16 


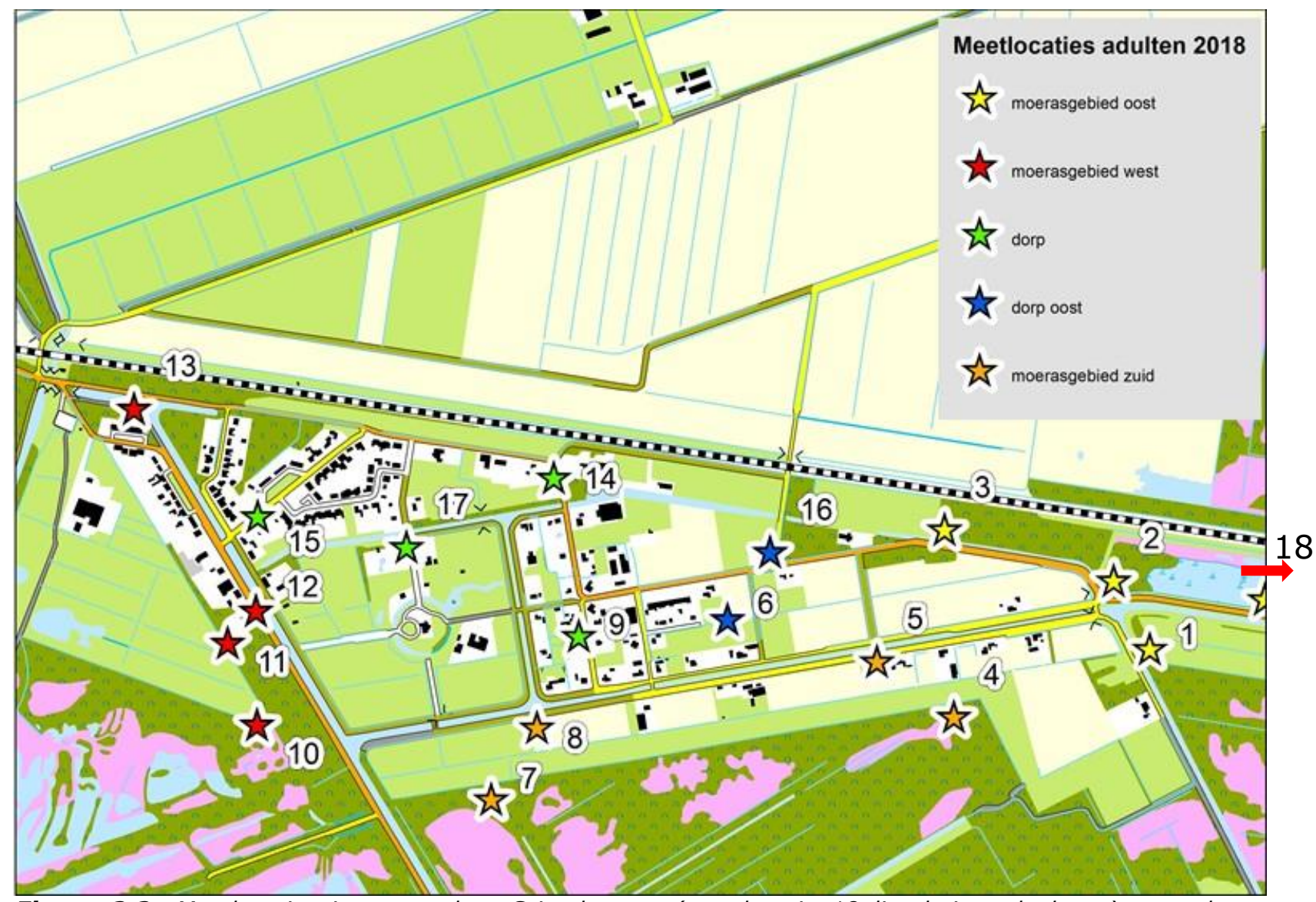

Figuur 2.2: Meetlocaties in en rondom Griendtsveen (meetlocatie 18 ligt buiten de kaart) voor de volwassen steekmuggen en knutten. Kleuren stippen duiden de zones aan.

Volwassen steekmuggen en knutten zijn maandelijks verzameld in de periode april tot en met september 2018. De zes meetrondes zijn uitgevoerd op:

- 17 en 18 april

- 15 en 16 mei

- 25 en 26 juni

- 17 en 18 juli

- 14 en 15 augustus

- 11 en 12 september

Tabel 2.1: Samenvattend overzicht van de meetlocaties per zone in en rondom Griendtsveen (voor nadere informatie zie Bijlage 1).

\begin{tabular}{ll}
\hline Zone & Locatie \\
\hline Oost moerasgebied & $1,2,3,18$ \\
Zuid moerasgebied & $4,5,7,8$ \\
Dorp oost & 6,16 \\
Dorp & $9,14,15,17$ \\
West moerasgebied & $10,11,12,13$ \\
\hline
\end{tabular}

\subsection{Bemonsteringstechnieken en milieugegevensverzameling}

\subsubsection{Larven}

De larven zijn bemonsterd met behulp van een Clarke dipper. Deze dipper bestaat uit een plastic bekertje aan een lange steel. Het bekertje wordt deels onder water gehouden zodat het oppervlakkige water inclusief de aanwezige steekmuglarven in de beker stromen. Als de beker deels gevuld is wordt deze boven 
water gedraaid. De dipper wordt in een witte bak geleegd waarna de larven worden geteld en, indien aan de orde, verzameld in een gelabeld potje met alcohol (75\%). De geconserveerde larven worden in het laboratorium op naam gebracht. Per locatie zijn 5 dips genomen.

\subsubsection{Volwassen stekende insecten}

Op iedere meetlocatie is een gecombineerde steekmuggen-knutten val voor het eind van de middag opgezet. Na het opzetten zijn de vallen geactiveerd en hebben gewerkt tot de volgende dag. In de loop van de ochtend zijn de vallen stopgezet, geleegd en opgehaald. Deze bemonsteringstechniek is een voor Europa gestandaardiseerde methode. Tellingen en determinaties van de gevangen steekmuggen en knutten zijn kort na de vangst uitgevoerd.

\subsubsection{Milieu-parameters}

Op alle locaties zijn milieu-parameters gemeten. Voor larven betrof dit parameters in het bemonsterde water en het deelgebied (Figuur 2.1) waarvan dit water deel uitmaakt. Een deelgebied is afgebakend op basis van de aanwezigheid van een homogeen vegetatietype en vergelijkbare waterpartijen. Per deelgebied zijn opgenomen: coördinaten, waterdiepte, lengte en breedte deelgebied, vegetatie type, mate van vegetatie bedekking, \% bedekking met water en inschatting permanentie van vochtigheid.

Op meetlocaties voor volwassen steekmuggen en knutten zijn temperatuur (minimum-maximum), luchtvochtigheid en beschaduwing gemeten.

De dagelijkse en maandelijkse neerslag- en temperatuurgegevens zijn verkregen via het KNMI (station Eindhoven). 


\section{Resultaten}

\subsection{Weers- en milieuomstandigheden}

Januari 2018 verliep zeer zacht, februari en maart waren koud (Figuur 3.1). April verliep weer zeer zacht en mei tot augustus waren zeer warm. Ook september tot en met november verliepen te warm.

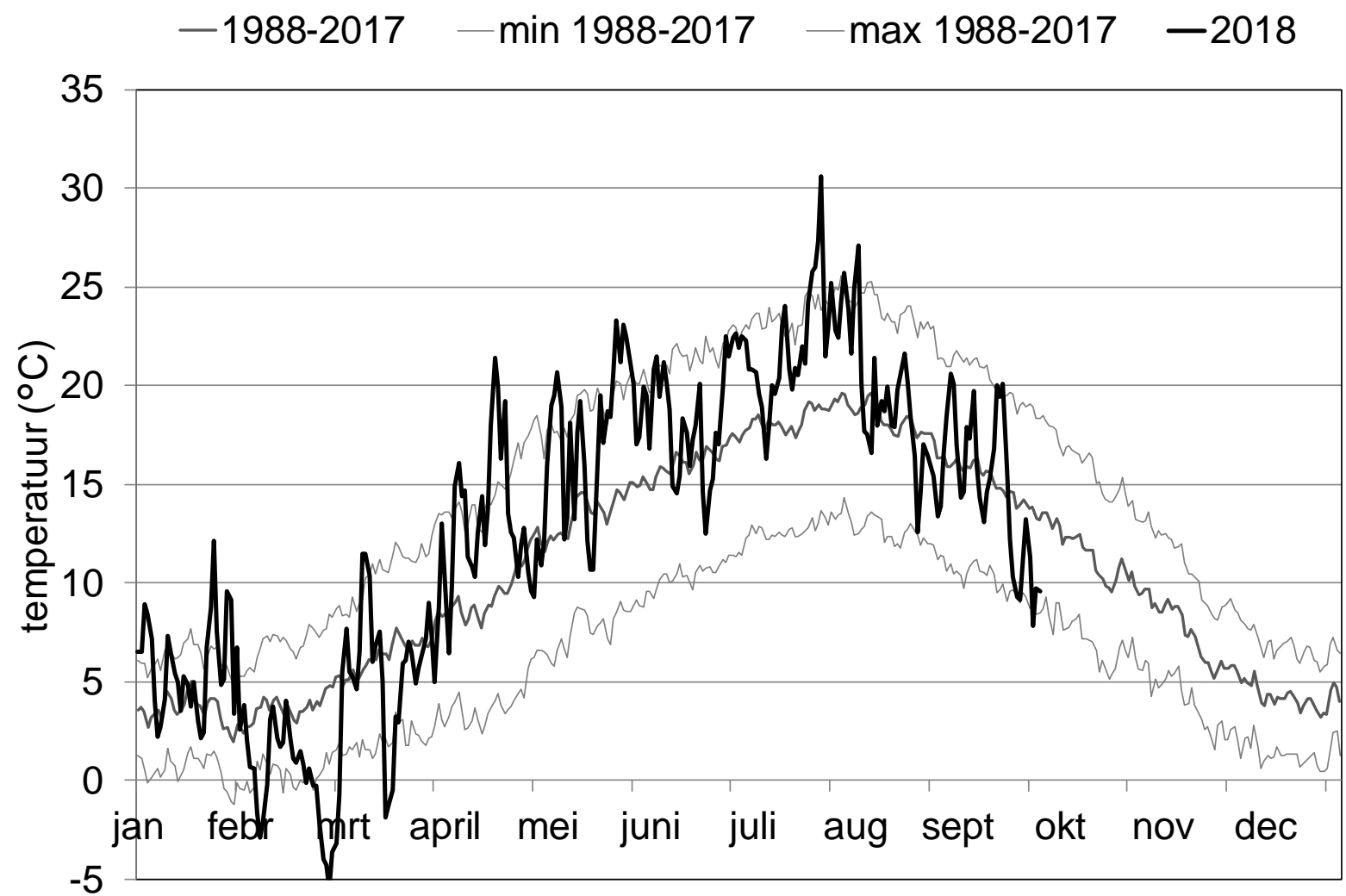

Figuur 3.1: Het verloop van de temperatuur over 30 jaar en over het jaar 2018 op station Eindhoven. Bron: http://www.knmi.nl/nederland-nu/klimatologie/daggegevens.

De winter 2017-2018 was kouder en de zomer van 2018 was warmer dan in de vier voorgaande jaren (Figuur 3.2).

Januari 2018 was vrij nat, februari was droog terwijl in maart en april een normale hoeveelheid neerslag viel (Figuur 3.3). Mei tot juli waren zeer tot record droog en augustus tot en met november waren eveneens te droog.

De vrij zachte, vrij natte en zonnige winter van 2018 bood geschikte omstandigheden voor de ontwikkeling van moerassteekmuggen. Door de toch koude maand maart en eerste helft van april kwamen de steekmuggen relatief laat op gang (Figuur 3.4). 


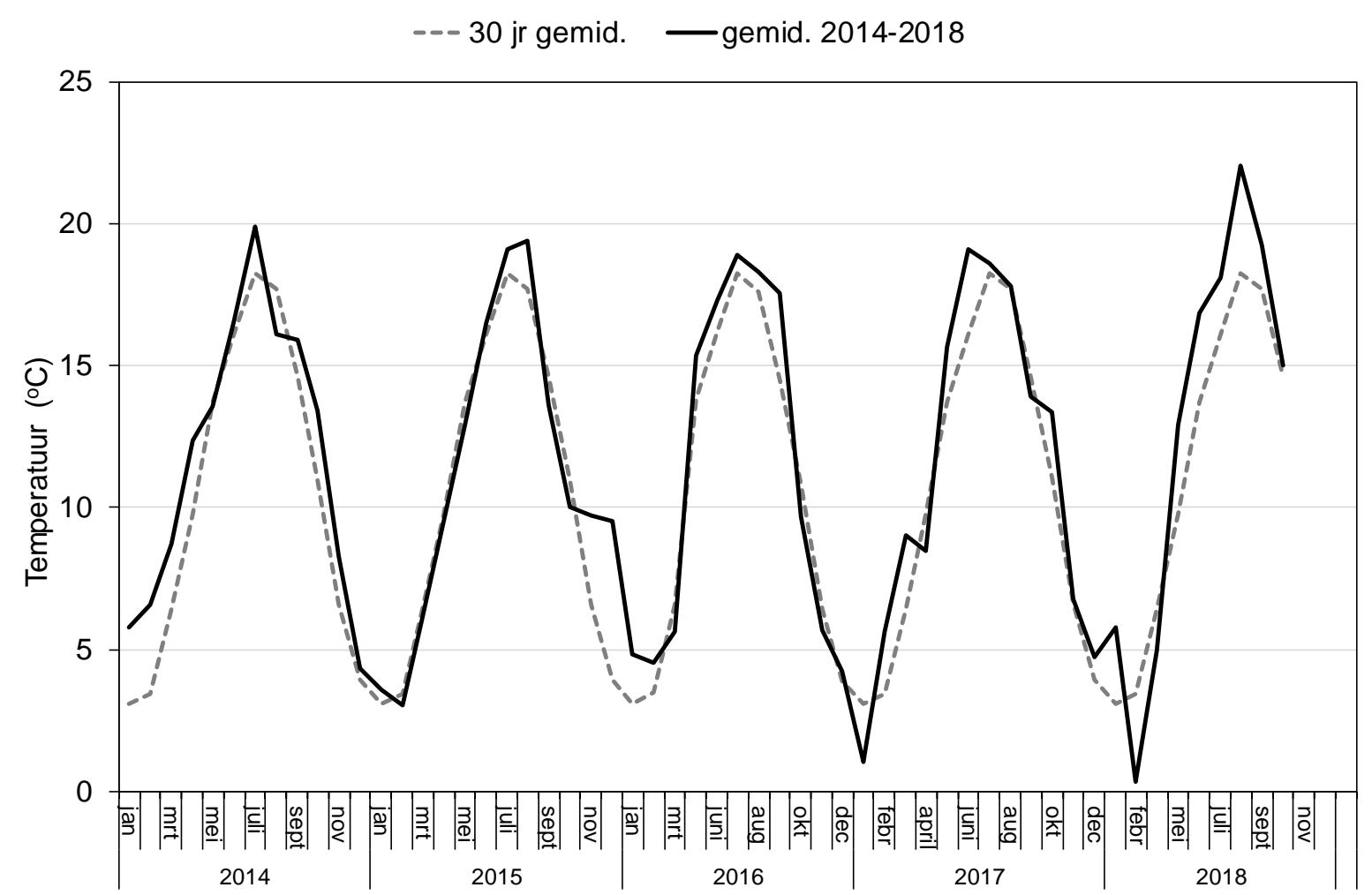

Figuur 3.2: Verloop van het maandgemiddelde van de temperatuur op station Eindhoven in 2014-2018 en het 30-jarig maandgemiddelde over de periode 1988-2017. Bron: KNMI: http://www.knmi.nl/nederland-nu/klimatologie/daggegevens.

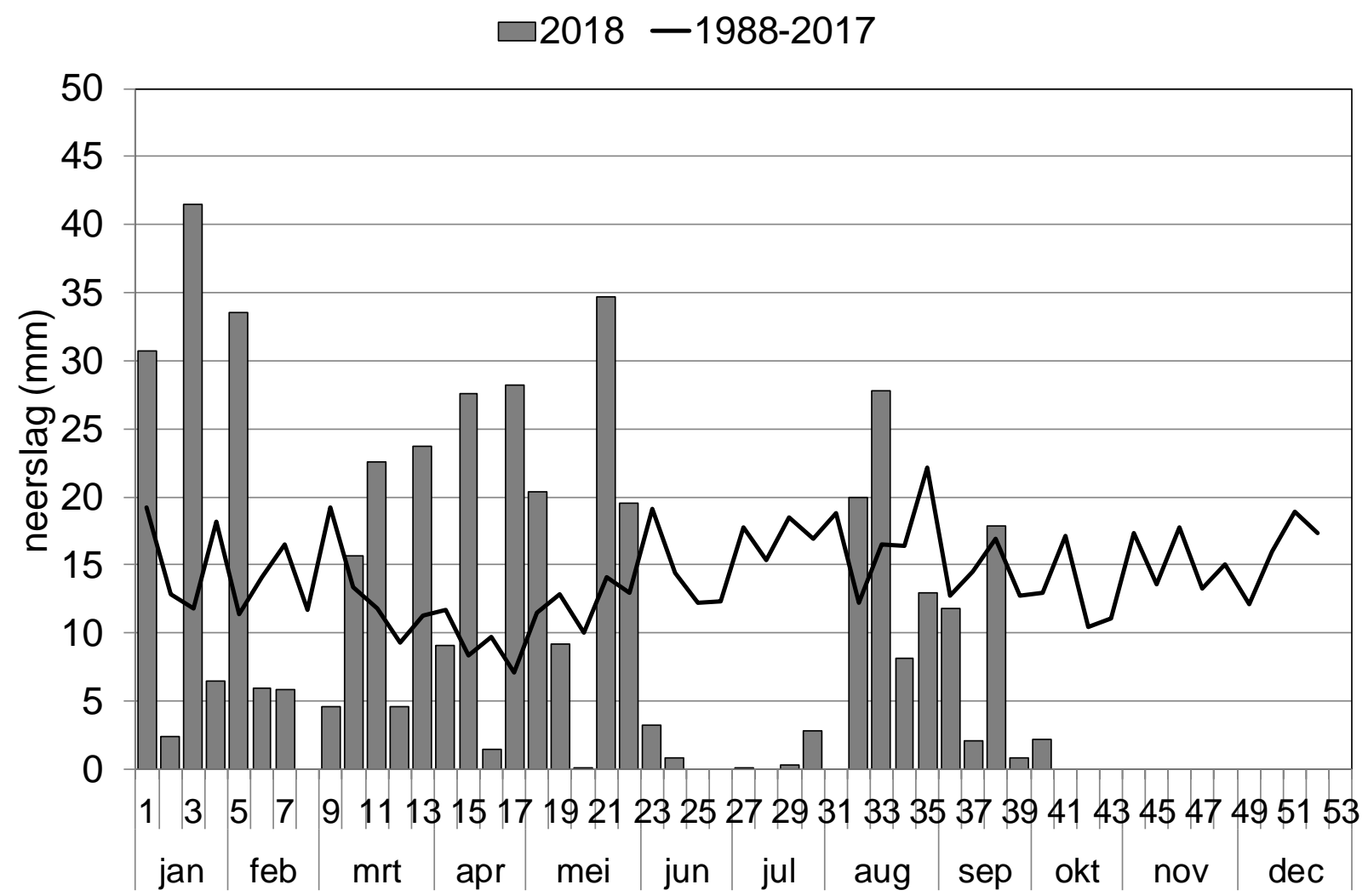

Figuur 3.3: Weeksom van de neerslag op station Eindhoven in 2018 en weeksom van daggemiddelden over de periode 1988-2017. Bron: http://www.knmi.nl/nederland-nu/klimatologie/daggegevens. 


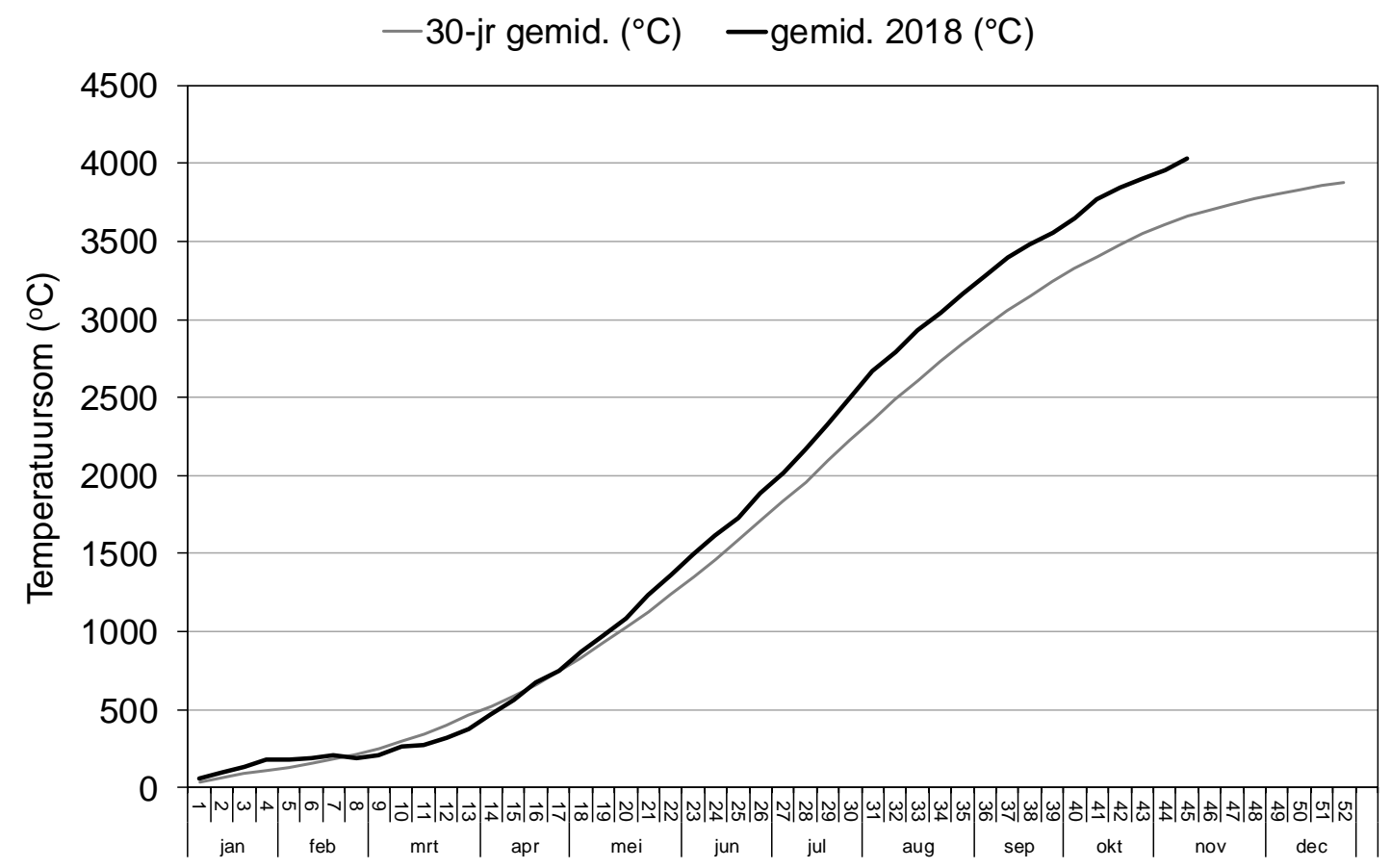

Figuur 3.4: Het cumulatieve verloop van de temperatuursom gemiddeld over 30 jaar en over het jaar 2018 op station Eindhoven.

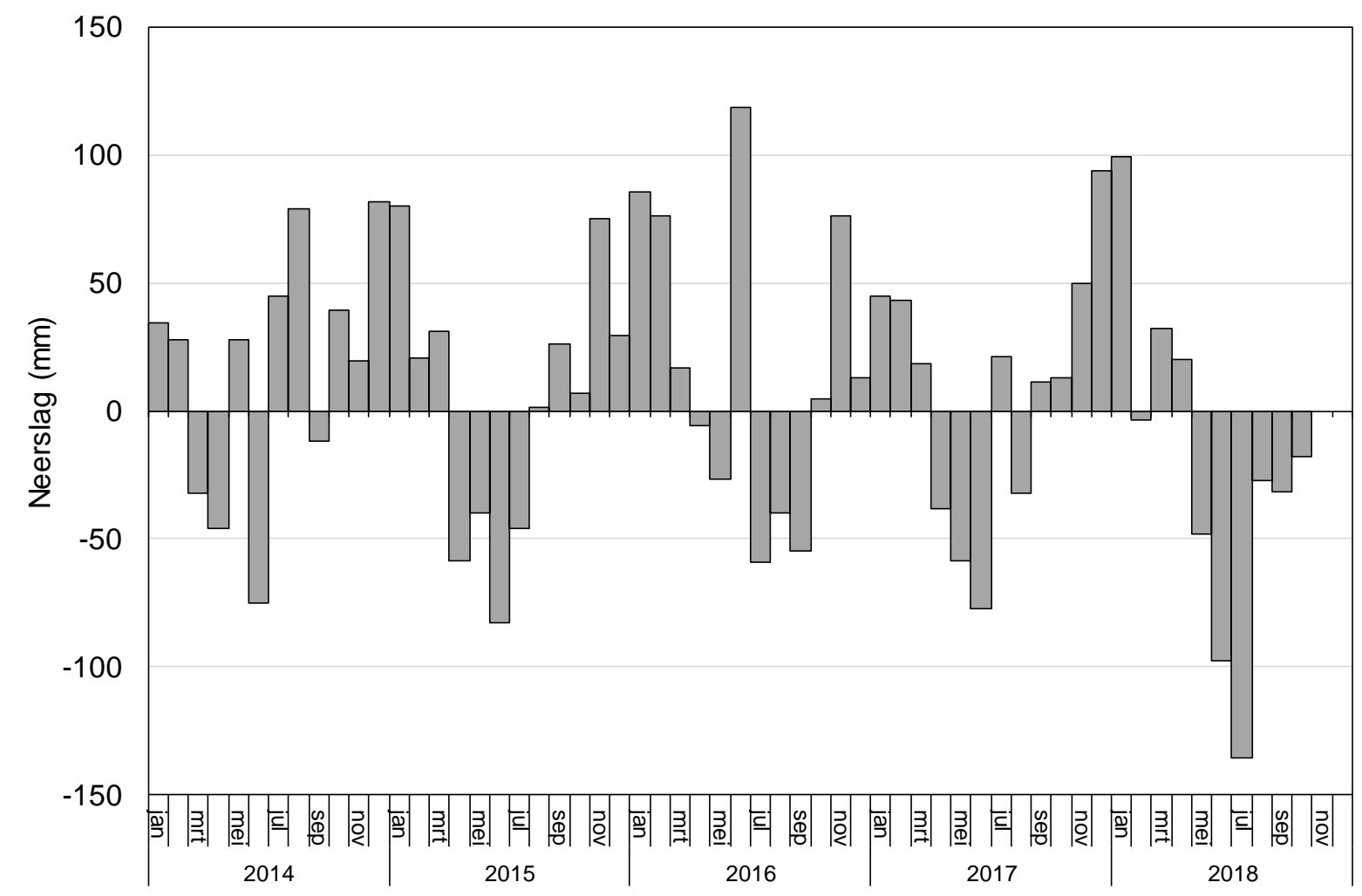

Figuur 3.5: Maandgemiddelde netto neerslag op station Eindhoven in 2014-2018 en het maandgemiddelde over de periode 1988-2017. Bron: KNMI: http://www.knmi.nl/nederlandnu/klimatologie/daggegevens. 
Door de extreem zachte, droge en zeer zonnige lente gevolgd door de extreem warme, zeer zonnige en zeer droge zomer droogden veel tijdelijke wateren op hetgeen ongunstig voor de ontwikkeling van moerasen huissteekmuggen was. De herfst van 2018 was zeer zonnig, zeer droog en vrij zacht.

De netto neerslag (bruto neerslag min verdamping) per maand (Figuur 3.5) laat duidelijk zien dat de winters normaal natter zijn dan de zomers. Daarnaast lijken de winters steeds droger te worden gaande van 2014 naar 2017, terwijl de winter 2018 juist natter was. Ook de extreme neerslag van juni 2016 komt duidelijk naar voren en de extreem lange droogte periode in 2018.

De vangstdagen waren april, mei en september koeler en op de overige meetdagen redelijk warm (Tabel 3.1). Koelere dagen kunnen de aantallen enigszins verlagen. De relatieve luchtvochtigheid was redelijk tot hoog. Er was nauwelijks sprake van neerslag. De wind was steeds zwak, behalve in mei wat de vangsten verlaagd kan hebben.

Tabel 3.1: Dagwaarden meteogegevens op station Eindhoven tijdens de meetdagen Bron: http://www.knmi.nl/nederland-nu/klimatologie/daggegevens.

\begin{tabular}{|c|c|c|c|c|c|c|c|c|c|c|c|c|c|}
\hline \multirow[t]{2}{*}{ Datum } & \multicolumn{3}{|c|}{ Temperatuur $\left({ }^{\circ} \mathbf{C}\right)$} & \multicolumn{3}{|l|}{ RV (\%) } & \multicolumn{2}{|c|}{ Neerslag } & \multicolumn{2}{|l|}{ Wind } & Bewolking & \multirow{2}{*}{$\begin{array}{l}\text { Zon } \\
\text { duur } \\
\text { (uur) }\end{array}$} & \multirow{2}{*}{$\begin{array}{l}\text { Luchtdruk } \\
\text { (hPa) }\end{array}$} \\
\hline & gemid & $\min$ & $\max$ & gemid & $\min$ & $\max$ & $\begin{array}{l}\text { duur } \\
\text { (uur) }\end{array}$ & $\begin{array}{l}\text { som } \\
(\mathrm{mm})\end{array}$ & richting & $\begin{array}{l}\text { snelheid } \\
(\mathrm{m} / \mathrm{s})\end{array}$ & (\%) & & \\
\hline 17 april 2018 & 13.7 & 3.9 & 22.2 & 67 & 37 & 97 & 0.0 & 0.0 & Z & 2.7 & 40 & 12.1 & 1025.0 \\
\hline 18 april 2018 & 18.0 & 6.2 & 25.6 & 55 & 28 & 96 & 0.0 & 0.0 & $\mathrm{O}$ & 2.1 & 50 & 12.5 & 1029.5 \\
\hline 15 mei 2018 & 19.2 & 11.6 & 24.9 & 53 & 29 & 90 & 0.0 & 0.0 & NO & 3.4 & 20 & 13.0 & 1015.2 \\
\hline 16 mei 2018 & 15.9 & 9.8 & 21.2 & 70 & 60 & 82 & 0.7 & 0.1 & $\mathrm{~N}$ & 5.1 & 60 & 7.3 & 1018.1 \\
\hline 25 juni 2018 & 17.6 & 12.2 & 23.4 & 68 & 43 & 90 & 0.0 & 0.0 & $\mathrm{~N}$ & 3.2 & 40 & 7.9 & 1025.0 \\
\hline 26 juni 2018 & 17.0 & 8.9 & 24.6 & 69 & 41 & 97 & 0.0 & 0.0 & $\mathrm{~N}$ & 3.1 & 50 & 12.3 & 1025.5 \\
\hline 17 juli 2018 & 20.8 & 11.5 & 28.1 & 60 & 40 & 88 & 0.0 & 0.0 & W & 3.6 & 30 & 12.2 & 1015.5 \\
\hline 18 juli 2018 & 19.8 & 10.1 & 26.2 & 58 & 35 & 94 & 0.0 & 0.0 & NW & 2.1 & 60 & 9.1 & 1018.6 \\
\hline 14 aug 2018 & 19.2 & 15.8 & 24.9 & 76 & 49 & 97 & 0.6 & 1.6 & W & 3.7 & 70 & 6.5 & 1014.9 \\
\hline 15 aug 2018 & 18.7 & 15.0 & 23.3 & 80 & 60 & 90 & 0.0 & 0.0 & ZW & 3.8 & 60 & 1.5 & 1018.8 \\
\hline 11 sept 2018 & 19.7 & 13.6 & 26.4 & 68 & 45 & 87 & 0.0 & 0.0 & ZW & 5.6 & 60 & 10.8 & 1021.0 \\
\hline 12 sept 2018 & 15.9 & 13.1 & 19.9 & 86 & 77 & 96 & 2.6 & 2.0 & $\mathrm{~N}$ & 3.5 & 80 & 0.0 & 1021.3 \\
\hline
\end{tabular}

\subsection{Larven van steekmuggen}

Tussen 1 en 14 mei 2018 zijn 104 locaties gedipt op larven van steekmuggen. Na half mei viel het grootste deel van het gebeid droog. Van al deze locaties stonden 76 locaties droog (Figuur 3.6; Bijlage 3). Op 28 locaties zijn larven van steekmuggen aangetroffen tegen 141 en 33 locaties in respectievelijk 2016 en 2017 (Tabel 3.2). Op de locaties waar larven aanwezig waren zijn de aantallen gemiddeld in 2018 gelijk aan 2017. De verspreiding van de meest dominante soort $A$. cinereus laat zien dat de larven gespreid over het gehele gebied voorkomen (Figuur 3.6)

In de weken daarna zijn opnieuw steekproeven genomen om te zien of locaties weer water gingen bevatten maar dat bleek niet meer op te treden. Daarom was een tweede gebiedsdekkende dipronde niet zinvol. 


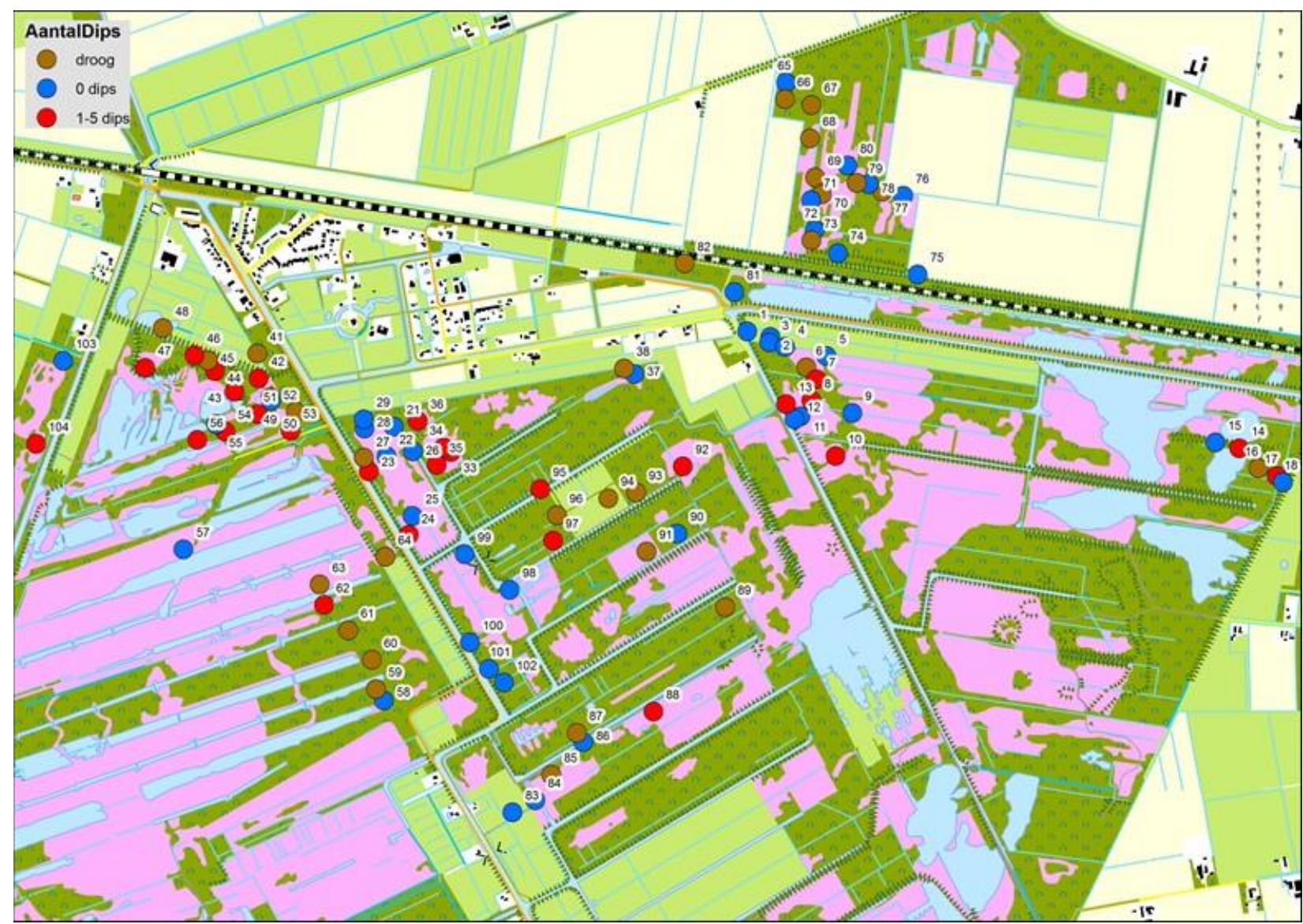

Figuur 3.6: Kaart van het onderzoeksgebied met bemonsteringslocaties voor de muggenlarven in 2018.

De eerste dip serie in maart 2017 en 2018 en de tweede serie in april 2018 laten zien dat in beide jaren nog geen larven verzameld konden worden (Tabel 3.2). Mogelijk waren de larven nog te klein door het koude voorjaar en verbleven ze op de bodem van de langdurig tijdelijke wateren. De vangmethode is niet geschikt om deze eerste stadia te verzamelen. De aantallen larven bleven in 2018 in totaal aanzienlijk lager t.o.v. 2016 (redelijk vergelijkbaar met de aantallen in 2017) omdat er veel minder poeltjes water bevatten (droogval vroeger in het seizoen), gemiddeld per poeltje waren de aantallen vergelijkbaar met 2017 en april 2016.

Tabel 3.2: Het aantal locaties met het totaal aantal larven (incl. poppen) van steekmuggen gebaseerd op series van 5 dips, verzameld per maand in de omgeving van Griendtsveen (voor nadere informatie zie Bijlage 3).

\begin{tabular}{|r|l|r|r|r|r|}
\hline Jaar & Maand & Maart & April & Mei & Juni \\
\hline 2016 & Aantal locaties met larven & 13 & 34 & 66 & 28 \\
\hline & Totaal aantal larven & 222 & 1024 & 1090 & 458 \\
\hline & Gemiddeld aantal larven & 17.1 & 30.1 & 16.6 & 16.4 \\
\hline 2017 & Aantal locaties met larven & $\mathrm{gw}$ & 9 & 24 & 0 \\
\hline & Totaal aantal larven & & 1601 & 950 & 0 \\
\hline & Gemiddeld aantal larven & & 177.9 & 39.6 & \\
\hline 2018 & Aantal locaties met larven & $\mathrm{gw}$ & $\mathrm{gw}$ & 28 & $\mathrm{gw}$ \\
\hline & Totaal aantal larven & & & 905 & \\
\hline & Gemiddeld aantal larven & & & 32.3 & \\
\hline
\end{tabular}




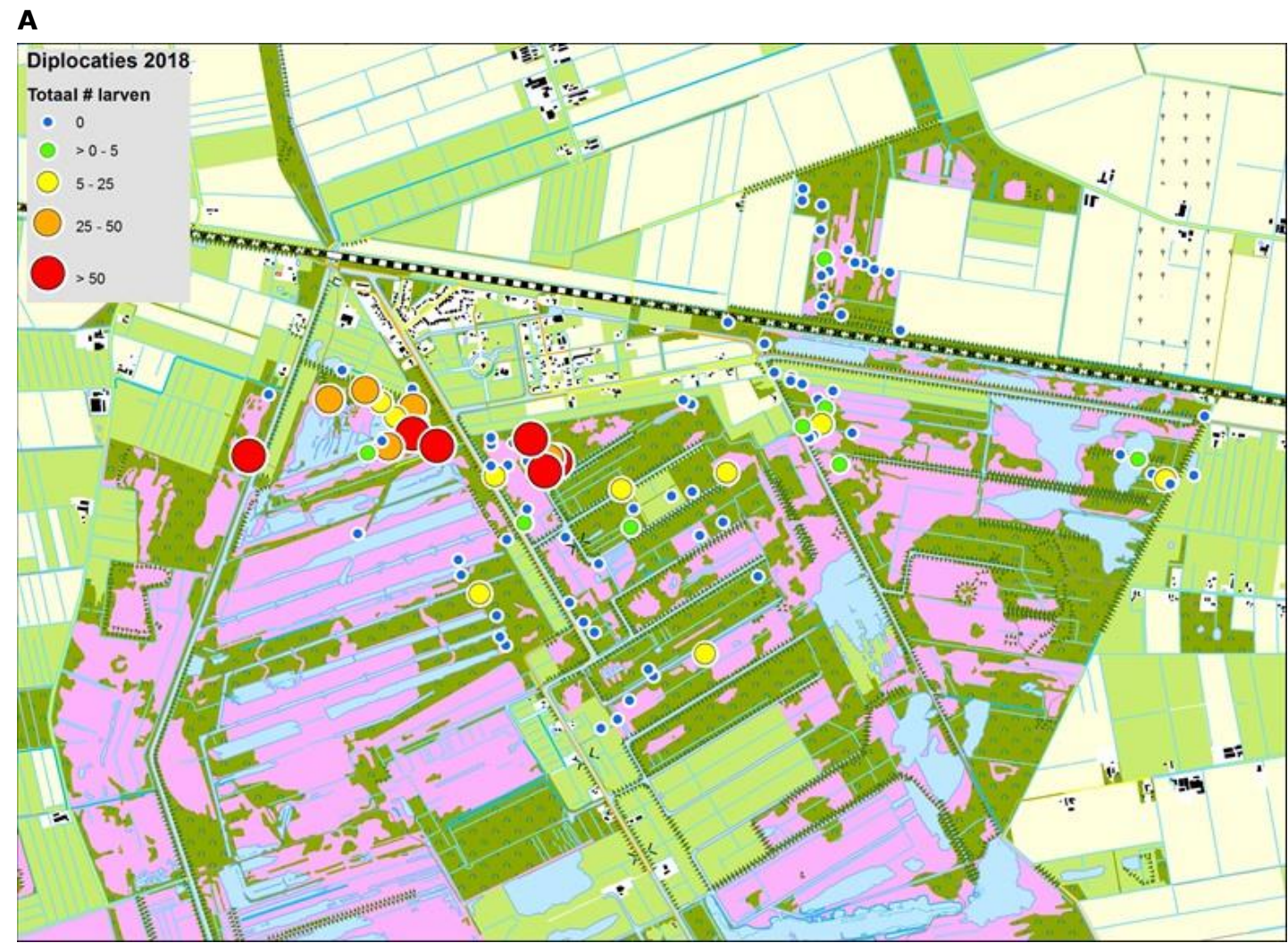

\section{B}

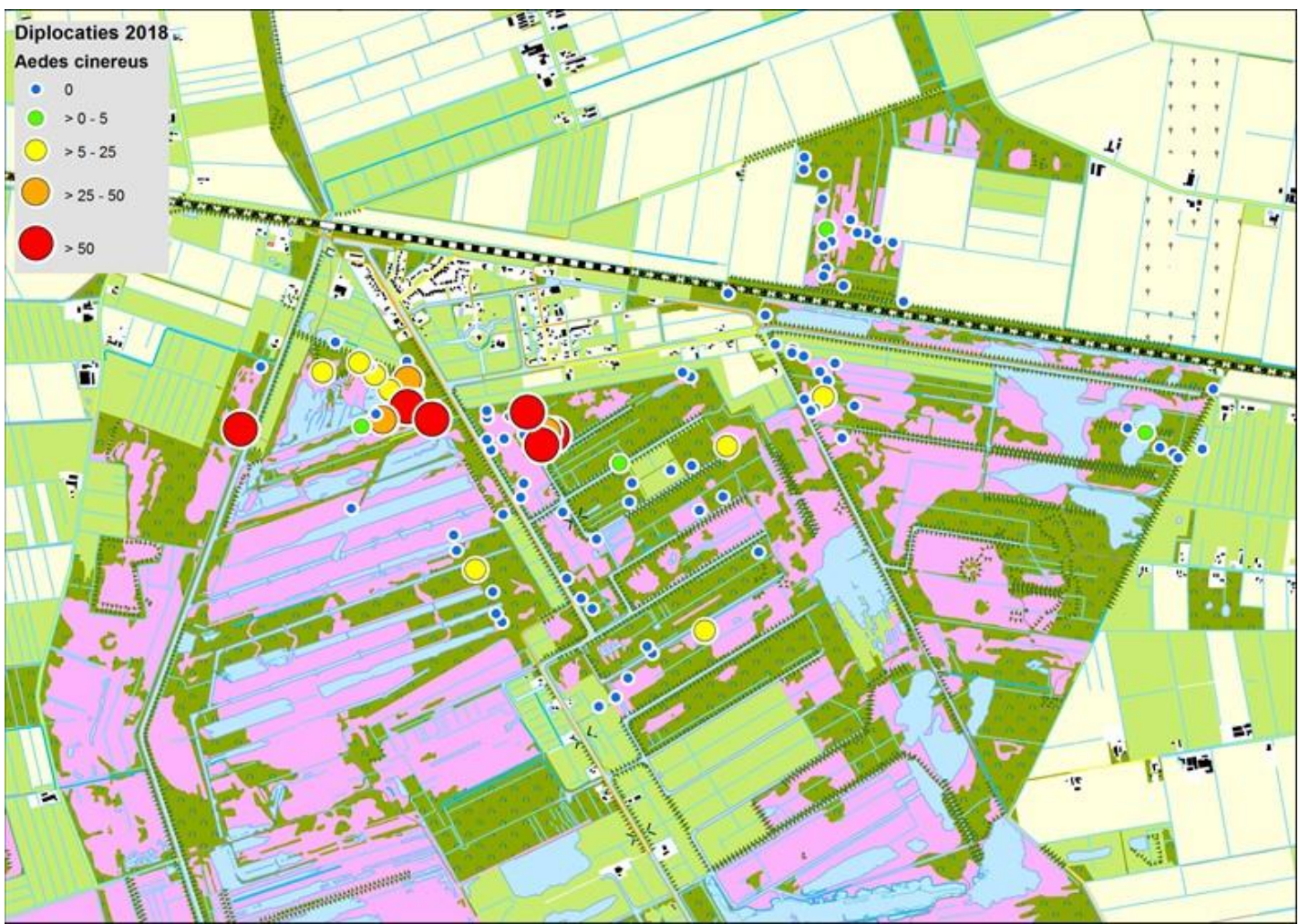

Figuur 3.6: Verspreiding van alle soorten steekmuglarven $(A)$ en larven van de moerassteekmug $A$. cinereus $(B)$ over het onderzoeksgebied. Kleuren geven de aantalsklassen weer van het totaal aantal larven per 5 dips. 
De bemonstering van larven in 2018 laat hogere aantallen zien op de voorheen benoemde hotspots 'Midden-west' (in compartiment XIV) en 'West' (ten zuidoosten van de Halte)(Figuur 3.6a). Vooral in het laatst genoemde gebied zijn de aantallen hoger. De aanwezigheid van water en larven is in vergelijking tot de rest van het gebied voldoende reden om deze hotspots als zodanig extra aandacht te geven. Het betreft op beide plekken ook vooral de soort Aedes cinereus (Figuur 3.6b). Daarnaast ligt ten westen van deze 'hotspot' ook nog een locatie met hoge aantallen. Mogelijk hangt dit samen met de vernattingsmaatregelen aan de westzijde in het buffergebied Leegveld.

Het herhaald dippen van larven op 5 vaste locaties leverde alleen op 18 april redelijke aantallen larven op, op 15 mei waren nog op twee van de vijf locaties larven aanwezig.

De verdeling van aantallen larven over de locaties laat de sterke dominantie van Aedes cinereus zien (Tabel 3.3). Ook in 2018 liggen de langdurig tijdelijke wateren redelijk verspreid door het gebied.

Tabel 3.3: Aantallen larven per soort gedipt op de locaties in mei 2018.

\begin{tabular}{|c|c|c|c|c|c|c|c|c|c|}
\hline Locatienr & Datum & $\mathbf{x}$ & $\mathbf{Y}$ & \begin{tabular}{l}
0 \\
1 \\
8 \\
5 \\
$\vdots$ \\
$\vdots$ \\
\hdashline \\
7
\end{tabular} & 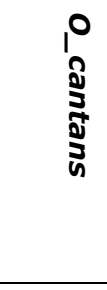 & $\frac{1}{3}$ & & 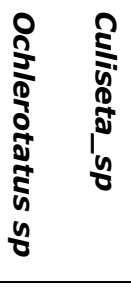 & 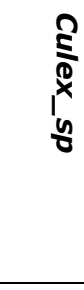 \\
\hline 7 & $1-\mathrm{mei}-18$ & 191233 & 383529 & & & 4 & & & \\
\hline 8 & $1-$ mei-18 & 191217 & 383455 & & 1 & & 13 & 1 & \\
\hline 10 & 1-mei-18 & 191301 & 383264 & & 1 & & & & \\
\hline 13 & 1 -mei-18 & 191129 & 383442 & & & 2 & & & \\
\hline 14 & 1-mei-18 & 192695 & 383290 & & & & 3 & & \\
\hline 17 & 1-mei-18 & 192825 & 383195 & & 9 & 3 & & & \\
\hline 23 & 7-mei-18 & 189688 & 383210 & & & 2 & & 2 & 2 \\
\hline 24 & 7-mei-18 & 189826 & 382992 & & & & & & 1 \\
\hline 33 & 7-mei-18 & 189971 & 383277 & & & 2 & 137 & & \\
\hline 34 & 7-mei-18 & 189946 & 383293 & & 3 & & 37 & & \\
\hline 35 & 7-mei-18 & 189922 & 385233 & & & & 112 & 4 & \\
\hline 36 & 7-mei-18 & 189856 & 383384 & & 10 & & 107 & & \\
\hline 42 & 8-mei-18 & 189307 & 383531 & & & & 28 & 13 & \\
\hline 43 & 8-mei-18 & 189223 & 383486 & & 1 & 2 & 12 & & \\
\hline 44 & 8-mei-18 & 189156 & 383556 & & & & 16 & & \\
\hline 46 & 8-mei-18 & 189085 & 383611 & & 4 & & 18 & 25 & \\
\hline 47 & 8-mei-18 & 188915 & 383568 & & 1 & & 25 & 1 & \\
\hline 51 & 8-mei-18 & 189304 & 383408 & & 1 & & 84 & 6 & \\
\hline 53 & 8-mei-18 & 189417 & 383351 & & & & 52 & 1 & \\
\hline 54 & 8-mei-18 & 189192 & 383347 & & 2 & & 30 & 1 & \\
\hline 56 & 8-mei-18 & 189095 & 383319 & & 1 & & 3 & & \\
\hline 61 & 8-mei-18 & 189617 & 383266 & & & & 7 & & \\
\hline 69 & 9-mei-18 & 191230 & 384225 & & & & 2 & & \\
\hline 88 & 14-mei-18 & 190671 & 382381 & & 2 & & 18 & 2 & \\
\hline 92 & 14-mei-18 & 190773 & 383228 & & 7 & & 12 & 1 & \\
\hline 95 & 14-mei-18 & 190280 & 383149 & & 5 & & 3 & & \\
\hline 97 & 14-mei-18 & 190324 & 382972 & & 1 & & & 2 & \\
\hline 104 & 14-mei-18 & 188537 & 383305 & & 1 & & 58 & 1 & \\
\hline
\end{tabular}




\subsection{Volwassen stekende insecten}

\subsubsection{Volwassen steekmuggen}

De milieu-omstandigheden van de bemonsteringslocaties zijn beschreven in bijlage 2 en met foto's geillustreerd in bijlage 6. De bemonstering in april leverde een beperkt aantal moerassteekmuggen (genus Ochlerotatus) op en 1 huissteekmug. Half mei zijn de extreem hoge aantallen steekmuggen verzameld van beide moerassteekmuggen genera Aedes en Ochlerotatus (Tabel 3.4). In juni lagen de aantallen op circa $10 \%$ t.o.v. mei en in de daaropvolgende maanden liepen de aantallen steeds verder terug. Het betrof in april-juni vooral moerassteekmuggen terwijl augustus-september vooral de huissteekmuggen aanwezig waren (Figuur 3.7). In juni en juli kwamen ook plantenboorsteekmuggen op (Coquillettidia).

Tabel 3.4: Aantallen volwassen steekmuggen per geslacht per maand in 2018.

\begin{tabular}{lrrrrrrr}
\hline & April & Mei & Juni & Juli & Augustus & September & Totaal \\
\hline Aedes & & 16917 & 847 & 228 & 2 & 10 & 18004 \\
Anopheles & & 148 & 34 & 54 & 50 & 18 & 304 \\
Coquillettidia & & & 229 & 414 & 30 & 1 & 674 \\
Culex & 1 & 46 & 434 & 174 & 203 & 164 & 1022 \\
Culiseta & & 6 & 6 & 29 & 23 & 9 & 73 \\
Ochlerotatus & 22 & 1669 & 15 & 8 & 3 & 2 & 1719 \\
\hline Totaal & $\mathbf{2 3}$ & $\mathbf{1 8 7 8 6}$ & $\mathbf{1 5 6 5}$ & $\mathbf{9 0 7}$ & $\mathbf{3 1 1}$ & $\mathbf{2 0 4}$ & $\mathbf{2 1 7 9 6}$ \\
\hline
\end{tabular}

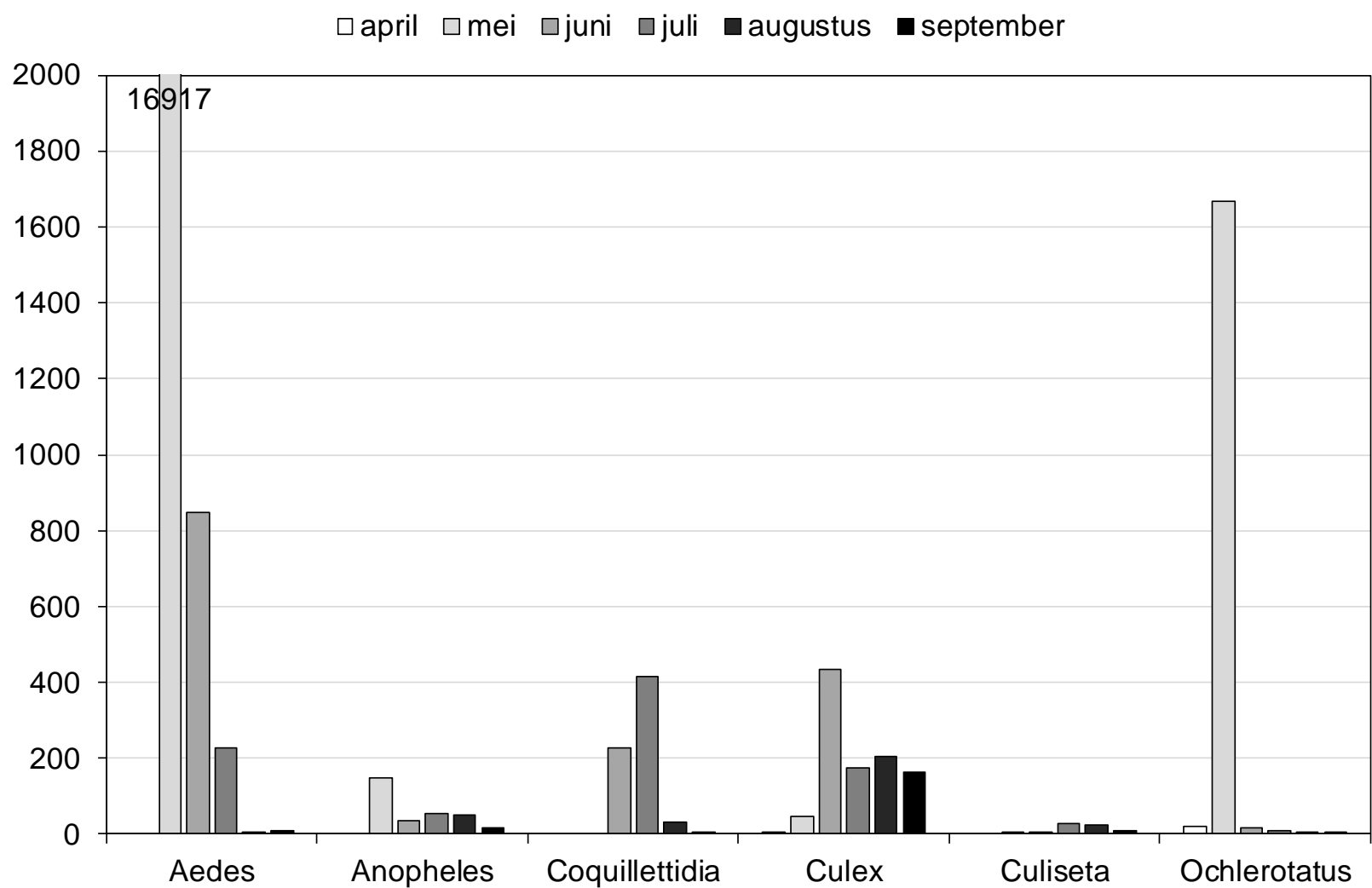

Figuur 3.7: Aantallen volwassen steekmuggen per geslacht per maand in 2018.

In 2018 was het totaal aantal gevangen steekmuggen in de maand mei extreem hoog, veel hoger dan in voorgaande jaren (Figuur 3.8). Dit hangt samen met de natte winter en het natte voorjaar. In 2015 namen de aantallen moerassteekmuggen vanaf het voorjaar toe met een maximum aantal in juli en speelden de huissteekmuggen nauwelijks een rol. In 2016 daarentegen waren de totale aantallen steekmuggen vanaf de maand juli hoog maar ging het vooral om huissteekmuggen. 


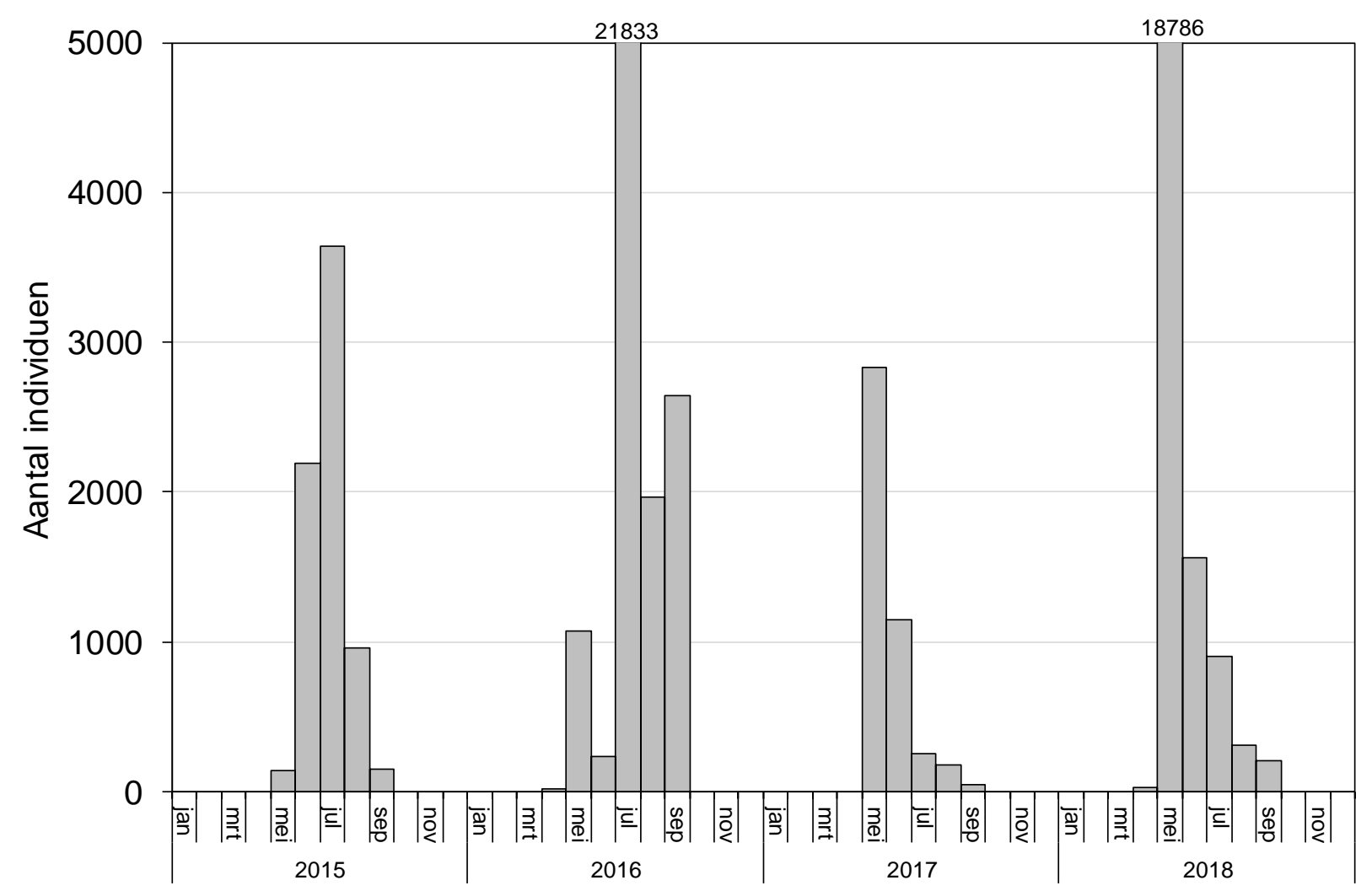

Figuur 3.8: Aantallen steekmuggen per maand over de jaren 2015-2018.

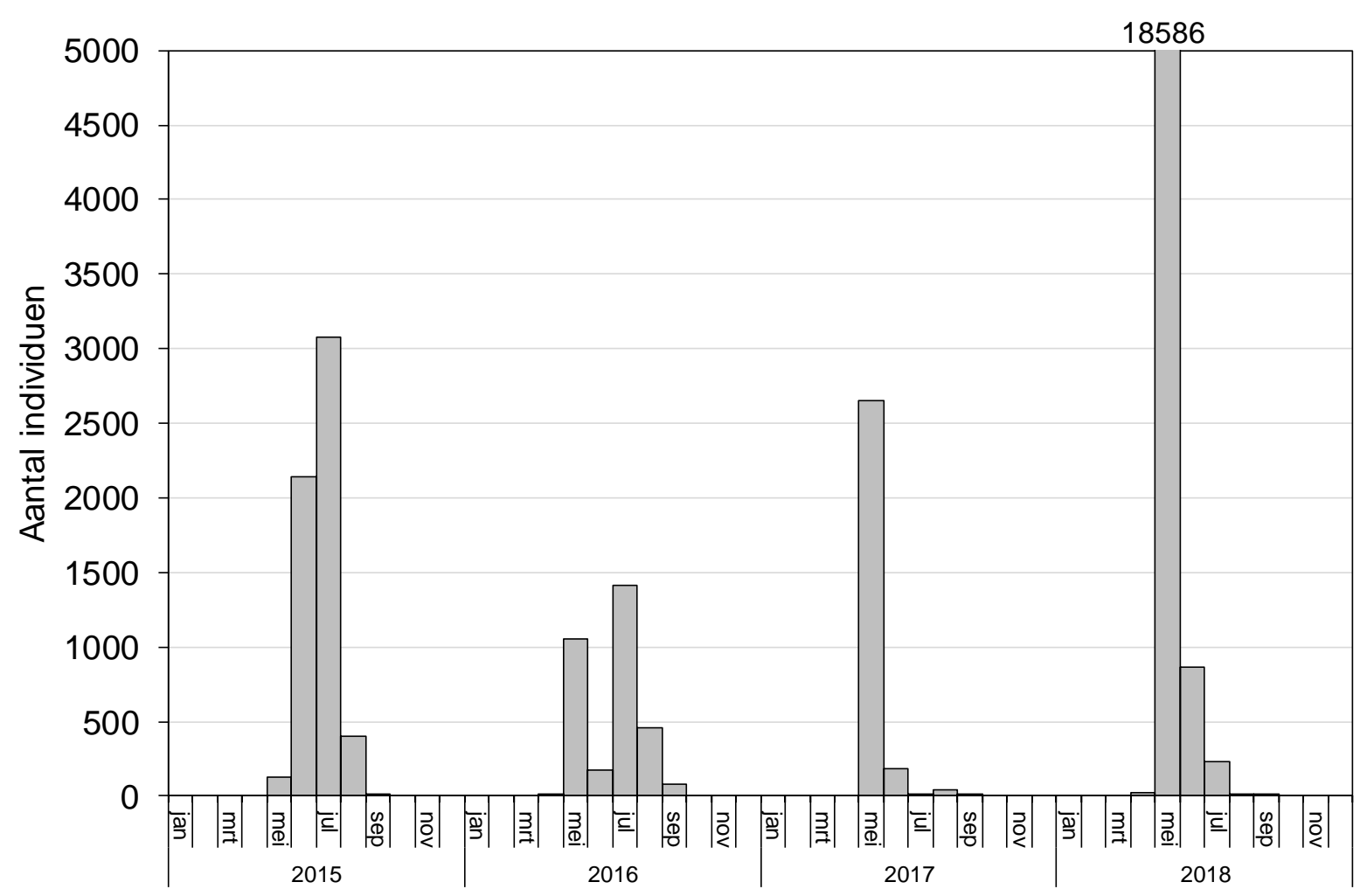

Figuur 3.9: Aantallen moerassteekmuggen (genera Aedes plus Ochlerotatus) per maand over de jaren 2015-2018. 
In 2015 werden in juni en juli de meeste moerassteekmuggen verzameld, in 2016 in mei en juli, in 2017 alleen in mei en in 2018 ook in mei met een uitloop tot juli (Figuur 3.9). Dit onregelmatige patroon in aantallen moerassteekmuggen hangt samen met de weersomstandigheden $(2016,2017)$ en de waterpeilen $(2015,2018)$ en daardoor de natheid van het gebied. Het patroon van 2015 kan niet alleen verklaard worden met de neerslag in 2015 omdat die bemonsteringen juist in een drogere periode vielen. In 2016 had de neerslag in april/mei en juni (extreme buien) wel zichtbaar invloed op de aantallen moerassteekmuggen. De droogte nadien leidde in 2017 tot lage aantallen moerassteekmuggen, behalve in de normale voorjaarssituatie in mei van dat jaar. In 2018 was de winter voorafgaand 'normaal' nat, de hoge aantallen zijn waarschijnlijk een gevolg van het peil in het gebied en of het verstoorde peil ten oosten van de lekkende kanaalkade (Figuur 3.9). Een verhoogt peil kan aanleiding zijn voor het gesynchroniseerd uitkomen van eitjes die in eerdere jaren hoger op de oeverzones en randen van pollen zijn afgezet.

Huissteekmuggen traden alleen talrijk op in 2016 van juli tot en met september. Deze hoge aantallen zijn direct gerelateerd aan de extreme weersomstandigheden in juni 2016 (Figuur 3.10). Ondanks de droge zomer van 2018 lagen de aantallen iets hoger t.o.v. 2017.

De plantenboorsteekmuggen zijn alleen in 2017 van belang in aantallen in de maand juni en in 2018 in de periode juni-juli (Figuur 3.11).

De slootsteekmuggen zijn nauwelijks van belang (Figuur 3.12).

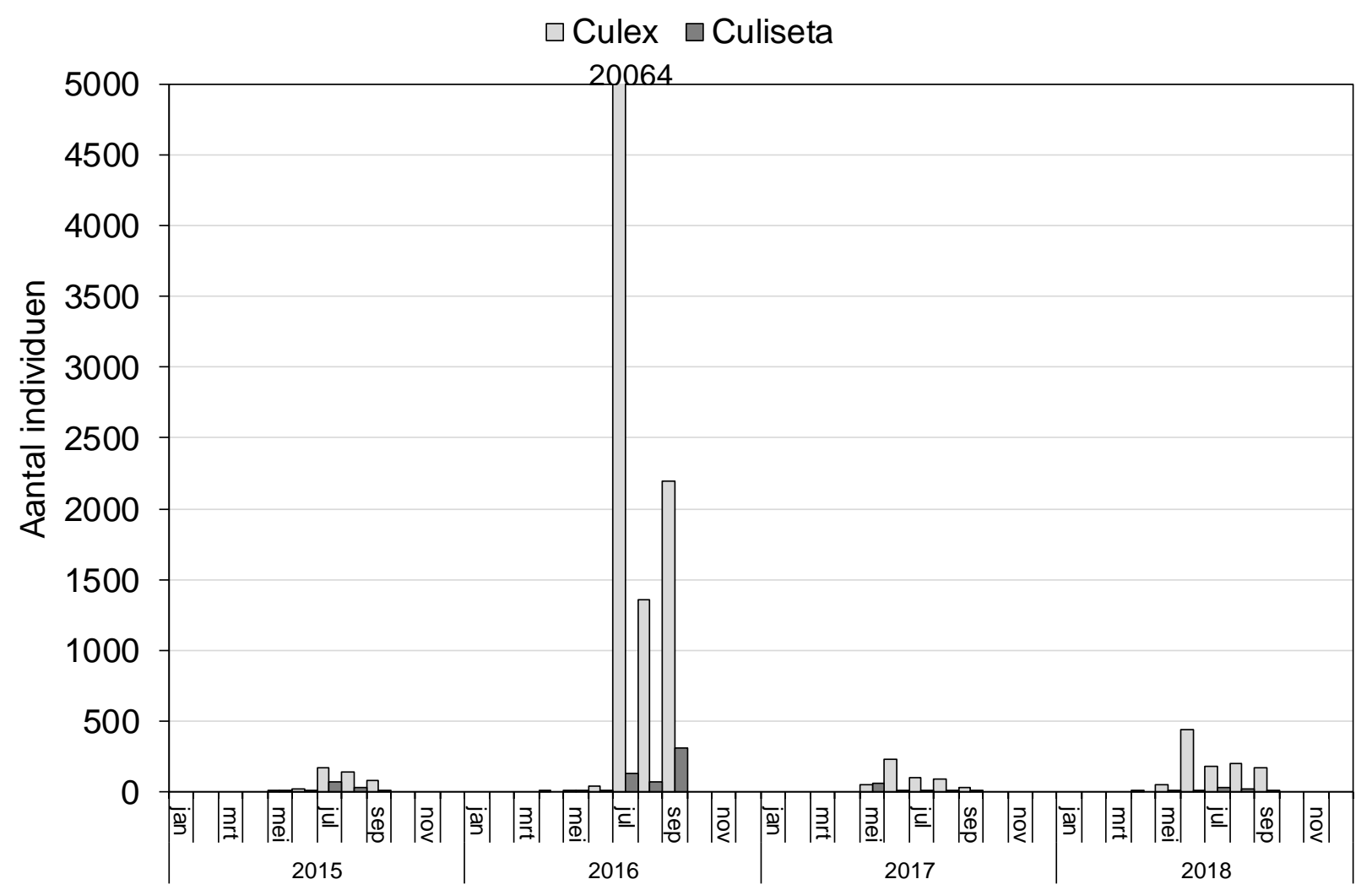

Figuur 3.10: Aantallen huissteekmuggen (genera Culex en Culiseta) per maand over de jaren 2015-2018. 


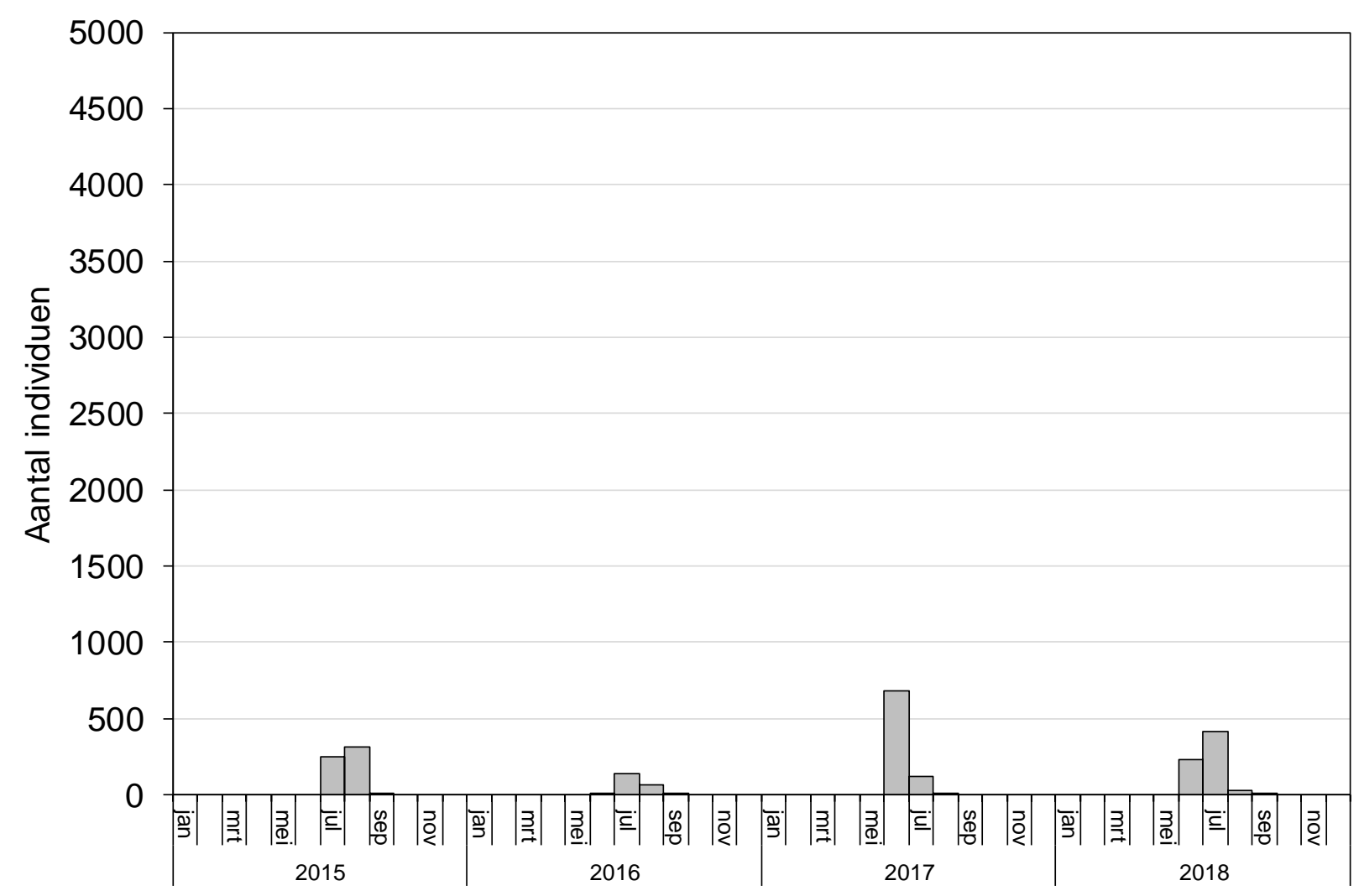

Figuur 3.11: Aantallen plantenboorsteekmuggen (genus Coquillettidia) per maand over de jaren 20152018.

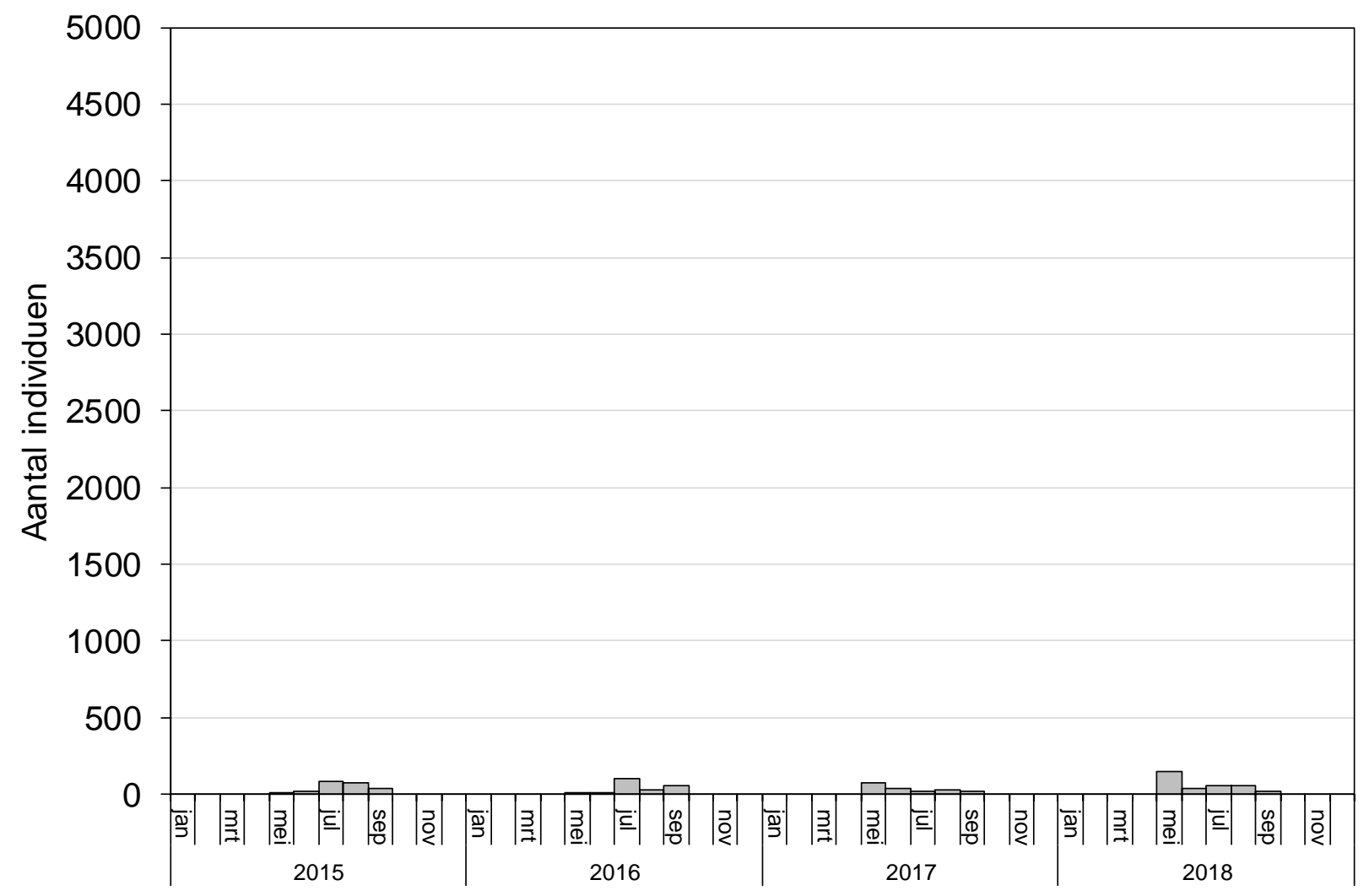

Figuur 3.12: Aantallen slootsteekmuggen (genus Anopheles) per maand over de jaren 2015-2018. 
Voor een gedetailleerd overzicht van aantallen per soort wordt verwezen naar bijlage 4 . Veel meer dan in voorgaande jaren was in 2018 de moerassteekmug Aedes cinereus het meest talrijk, gevolgd door de huissteekmug Culex pipiens (Tabel 3.5). De moerassteekmuggen namen $82 \%$ van het totale aantal in en de huissteekmuggen nog geen $10 \%$ in (Tabel 3.5).

Over de laatste vier jaren trad alleen in 2016 een verschuiving tussen soorten op met in 2015 een dominantie van $A$. cinereus, in 2016 van C. pipiens door de extreme natheid in juli, en in 2017 en 2018 weer van A. cinereus. Trad C. pipiens in 2016 door de extreme regenval in extreme aantallen op, in 2018 was $A$. cinereus extreem talrijk aanwezig. De aantallen van de eerder toenemende soort 0 . punctor, daalden in 2018 weer tot de helft. Nieuw in 2018 zijn A. vexans, een soort bekend van rivieruiterwaarden en beekmoerassen, en $C$. modestus, een aan $C$. pipiens verwante soort. De eerst genoemde soort berust waarschijnlijk op een incidenteel voorkomen en er is geen reden te verwachten dat deze soort zich uitbreidt. De tweede soort kan wel vaker (gaan) voorkomen maar vertoont vergelijkbaar gedrag en habitat met C. pipiens.

Tabel 3.5: Totale aantallen steekmuggen per soort over de jaren 2015-2018.

\begin{tabular}{lrrrrrrrr}
\hline & $\mathbf{2 0 1 5}$ & $\mathbf{2 0 1 5}$ & $\mathbf{2 0 1 6}$ & $\mathbf{2 0 1 6}$ & $\mathbf{2 0 1 7}$ & $\mathbf{2 0 1 7}$ & $\mathbf{2 0 1 8}$ & $\mathbf{2 0 1 8}$ \\
\cline { 2 - 9 } Taxon & Aantal & \% & Aantal & \% & Aantal & $\%$ & Aantal & $\%$ \\
\hline Aedes vexans & & & & & & & 2 & 0.0 \\
Aedes cinereus & 5082 & 71.8 & 1901 & 6.8 & 1480 & 33.2 & 18002 & 82.6 \\
Ochlerotatus punctor & 293 & 4.1 & 909 & 3.3 & 1033 & 23.2 & 1458 & 6.7 \\
Ochlerotatus cantans & 388 & 5.5 & 375 & 1.4 & 386 & 8.7 & 261 & 1.2 \\
Ochlerotatus sp. & & & & & 2 & 0.04 & & \\
Anopheles gr. maculipennis & 111 & 1.6 & 89 & 0.3 & 86 & 1.9 & 232 & 1.1 \\
Anopheles plumbeus & 101 & 1.4 & 112 & 0.4 & 85 & 1.9 & 72 & 0.3 \\
Culex pipiens & 418 & 5.9 & 23583 & 84.9 & 477 & 10.7 & 995 & 4.6 \\
Culex territans & & & 73 & 0.3 & 12 & 0.3 & 1 & 0.0 \\
Culex modestus & & & & & & & 26 & 0.1 \\
Culiseta annulata & 30 & 0.4 & 106 & 0.4 & 17 & 0.4 & 24 & 0.1 \\
Culiseta morsitans & 96 & 1.4 & 417 & 1.5 & 66 & 1.5 & 49 & 0.2 \\
Coquillettidia richiardii & 562 & 7.9 & 211 & 0.8 & 813 & 18.2 & 674 & 3.1 \\
\hline Totaal & $\mathbf{7 0 8 1}$ & $\mathbf{1 0 0}$ & $\mathbf{2 7 7 7 6}$ & $\mathbf{1 0 0}$ & $\mathbf{4 4 5 7}$ & $\mathbf{1 0 0}$ & $\mathbf{2 1 7 9 4}$ & $\mathbf{1 0 0}$ \\
\hline
\end{tabular}

De verdeling van de aantallen over de locaties laat zien dat de hoogste aantallen gevangen zijn op veldlocatie oost, zuid, en west (Tabel 3.6, Figuur 3.13, 3.14). De aantallen zijn lager bij nagenoeg alle huislocaties.

Tabel 3.6: Aantal steekmuggen per locatie per maand in 2018.

\begin{tabular}{llrrrrrrr}
\hline Zone & Locatie & April & Mei & Juni & \multicolumn{1}{c}{ Juli } & Augustus September & Totaal \\
\hline Oost & veld 1 & 1 & 1982 & 226 & 133 & 16 & 9 & 2367 \\
Oost & veld 2 & & 1104 & 91 & 70 & 9 & 11 & 1285 \\
Oost & veld 3 & & 1160 & 79 & 63 & 41 & & 1343 \\
Oost & huis 18 & 4 & 239 & 41 & 13 & 15 & 11 & 323 \\
Zuid & veld 4 & & 1940 & 80 & 40 & 5 & 4 & 2069 \\
Zuid & veld 5 & 3 & 1600 & 75 & 49 & 23 & 11 & 1761 \\
Zuid & veld 7 & 4 & 904 & 104 & 43 & 19 & 14 & 1088 \\
Zuid & veld 8 & & 800 & 45 & 8 & 10 & 1 & 864 \\
West & veld 10 & & 3356 & 194 & 177 & 8 & 6 & 3741 \\
West & veld 11 & & 1624 & 124 & 34 & 16 & 11 & 1809 \\
West & huis 12 & & 291 & 18 & 28 & 5 & 5 & 347 \\
West & huis 13 & 344 & 10 & 12 & 14 & 3 & 383
\end{tabular}




\begin{tabular}{|c|c|c|c|c|c|c|c|c|}
\hline Dorp oost & huis 6 & & 1992 & 121 & 69 & 31 & 19 & 2232 \\
\hline Dorp oost & huis 9 & 7 & 553 & 97 & 61 & 48 & 19 & 785 \\
\hline Dorp & huis 14 & 4 & 469 & 16 & 45 & 16 & 60 & 610 \\
\hline Dorp & huis 15 & & 125 & 35 & 2 & 7 & 9 & 178 \\
\hline Dorp & huis 16 & & 171 & 118 & 45 & 9 & 4 & 347 \\
\hline Dorp & huis 17 & & 132 & 91 & 15 & 19 & 7 & 264 \\
\hline
\end{tabular}

Wanneer we specifiek naar de moerassteekmuggen kijken dan zijn de aantallen op locatie huis 6 even hoog als in het veld (locaties 4 en 5) en bij locatie huis 9 een derde van de aantallen in de bosranden. In het dorp zijn de aantallen een zevende tot een tiende (Figuur 3.13, 3.15, Tabel 3.6).

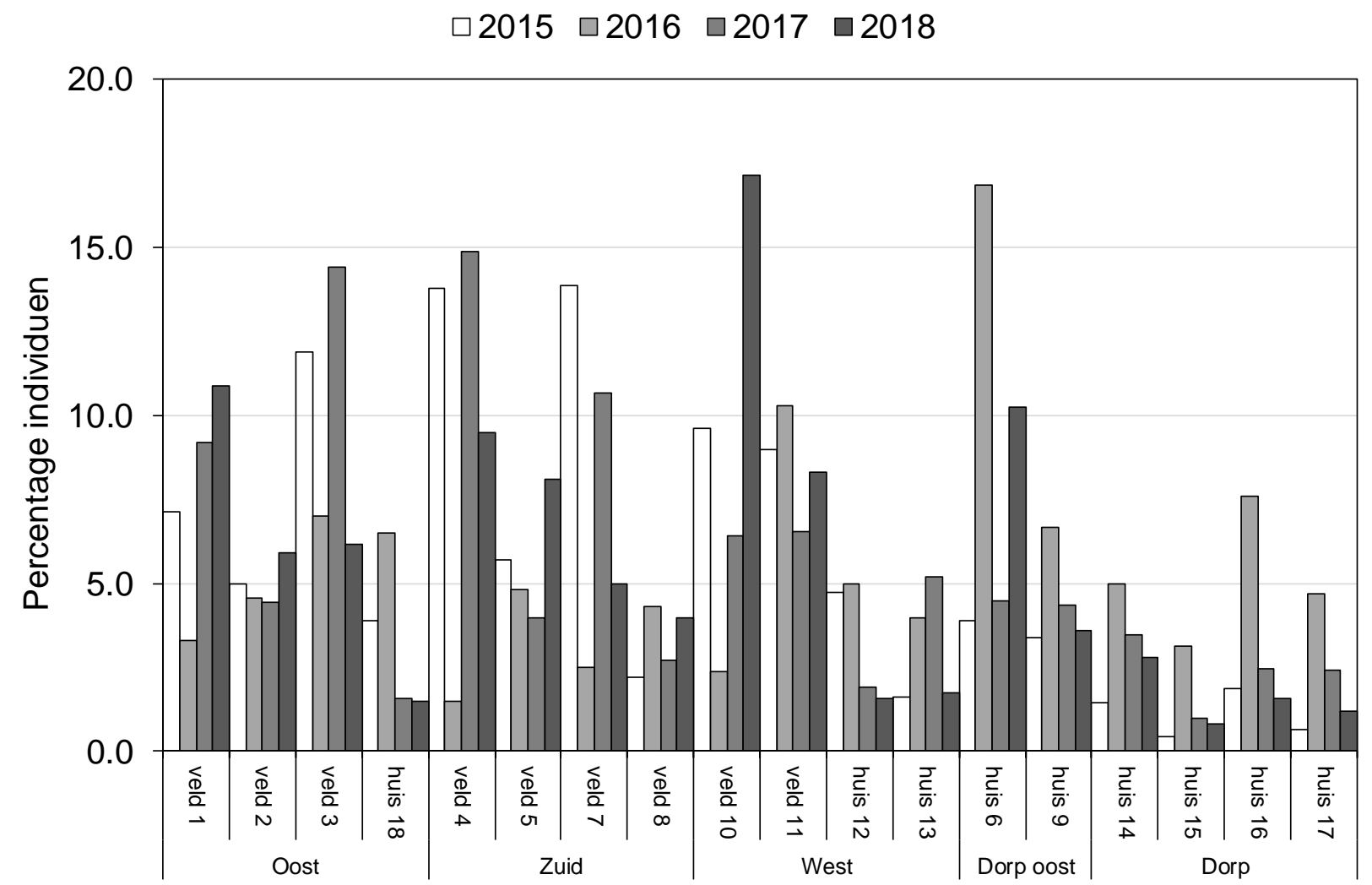

Figuur 3.13: Aantallen steekmuggen per locatie in 2015, 2016 en 2017. 


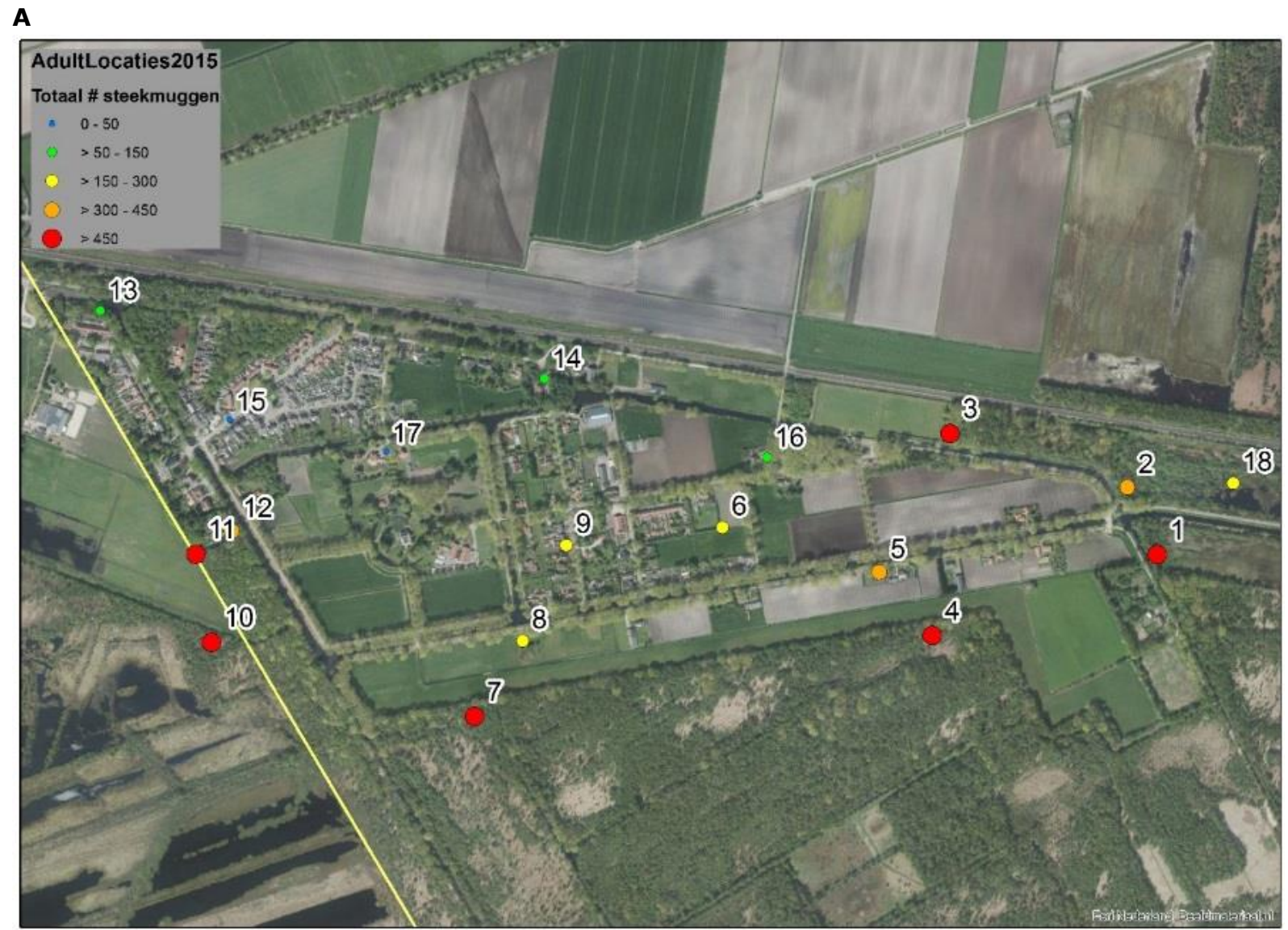

B

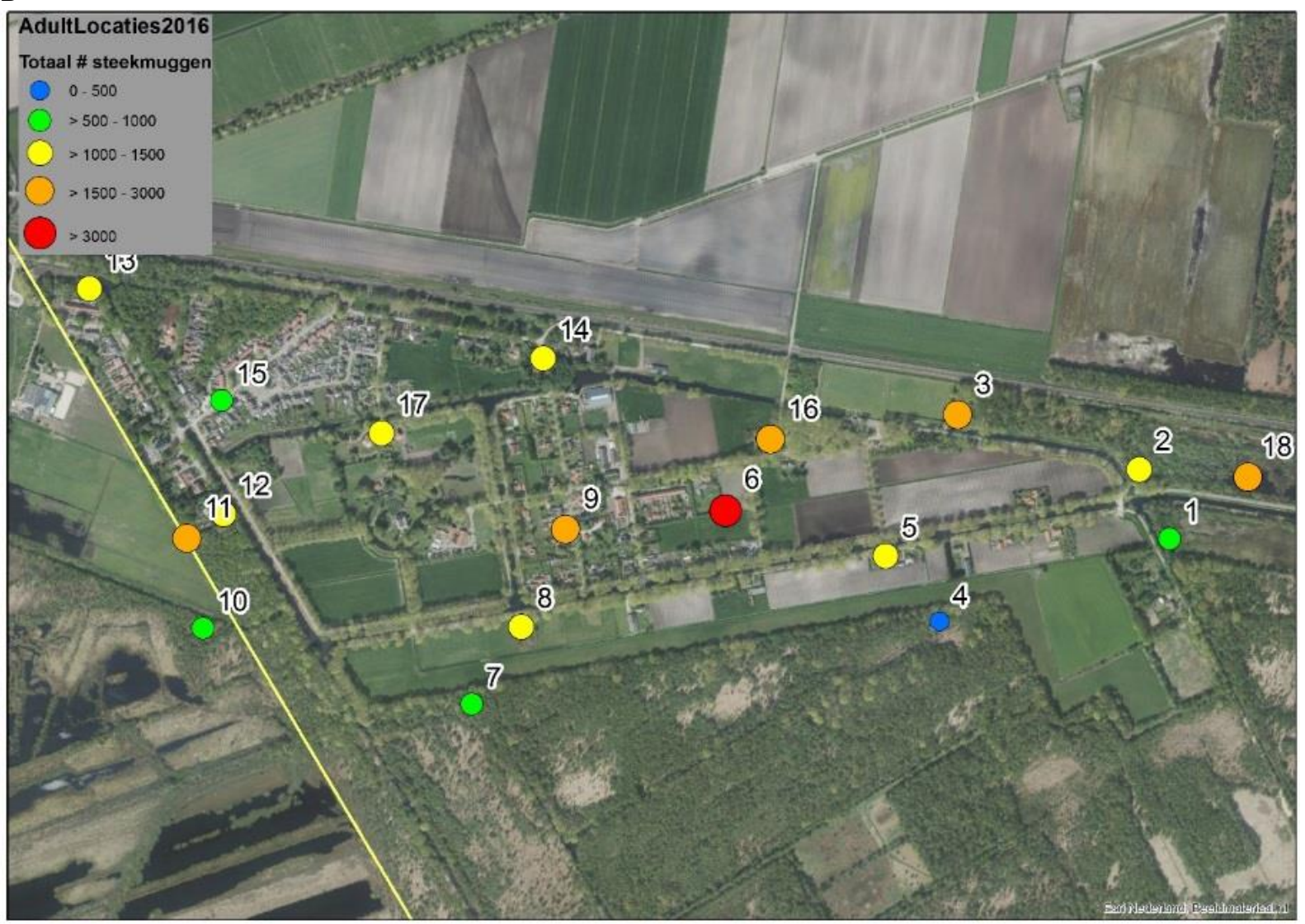




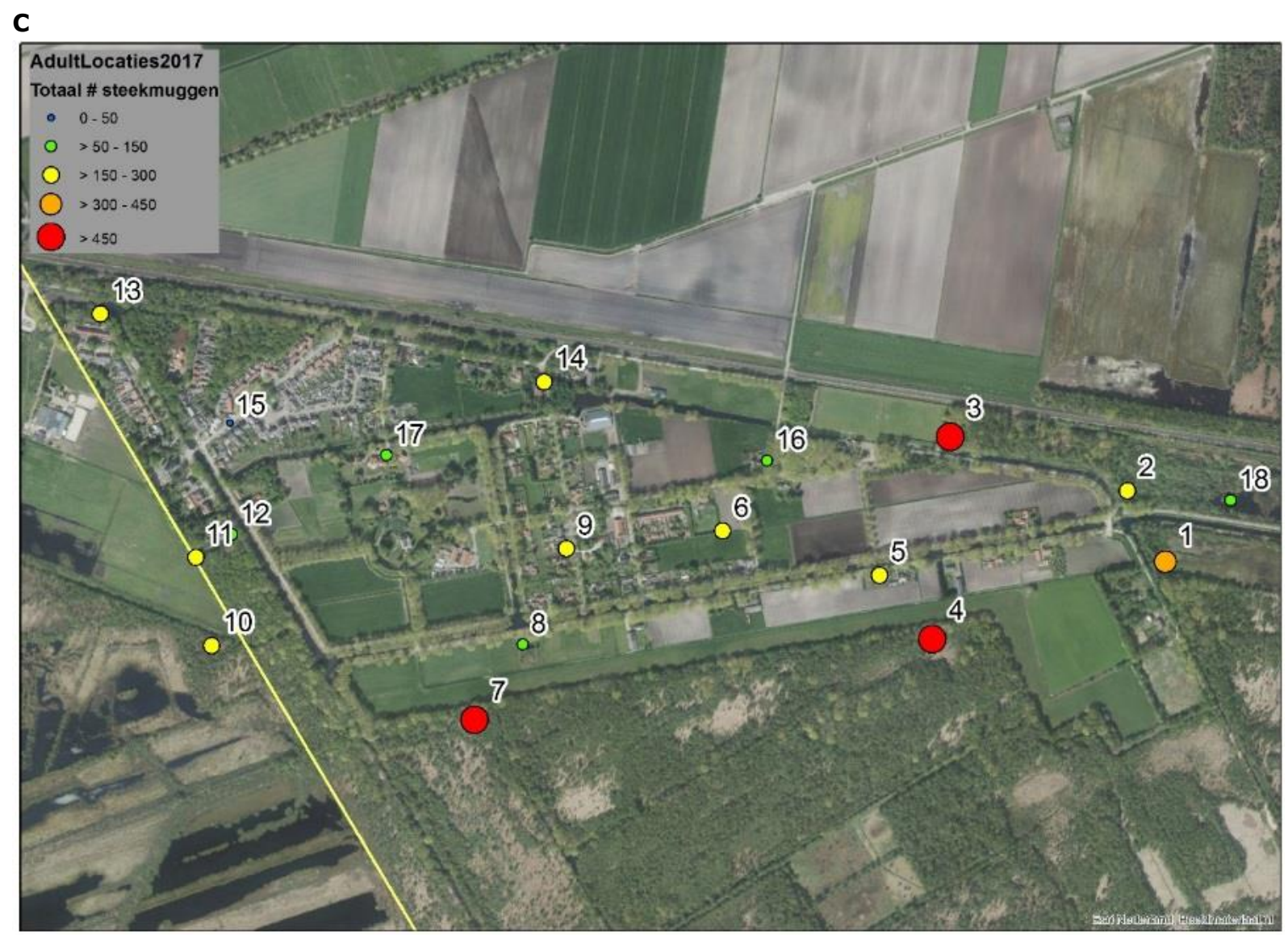

\section{D}

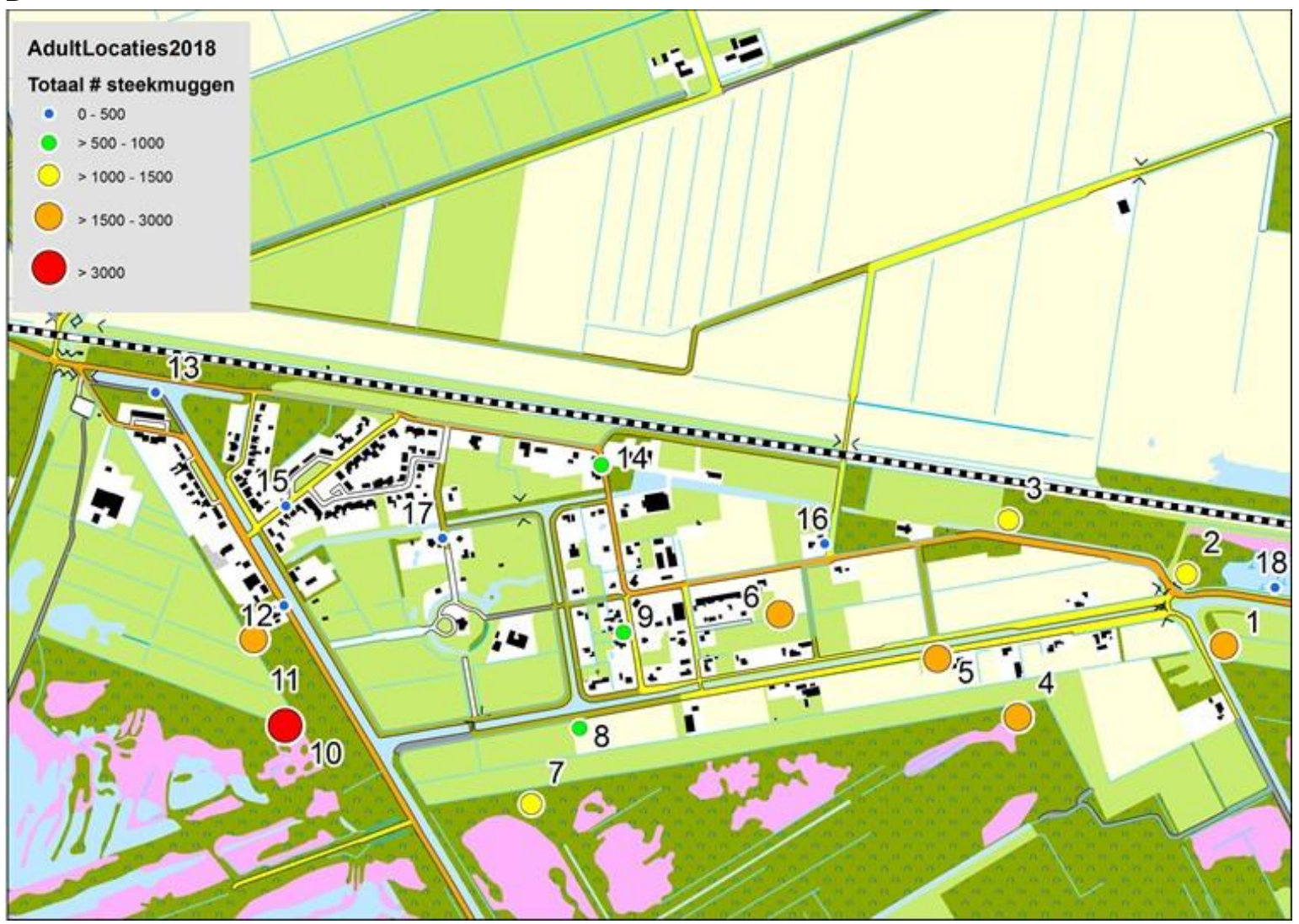

Figuur 3.14: Aantallen steekmuggen, uitgedrukt in aantalsklassen per locatie, in 2015 (A), 2016 (B), 2017 (C) en 2018 (D). 


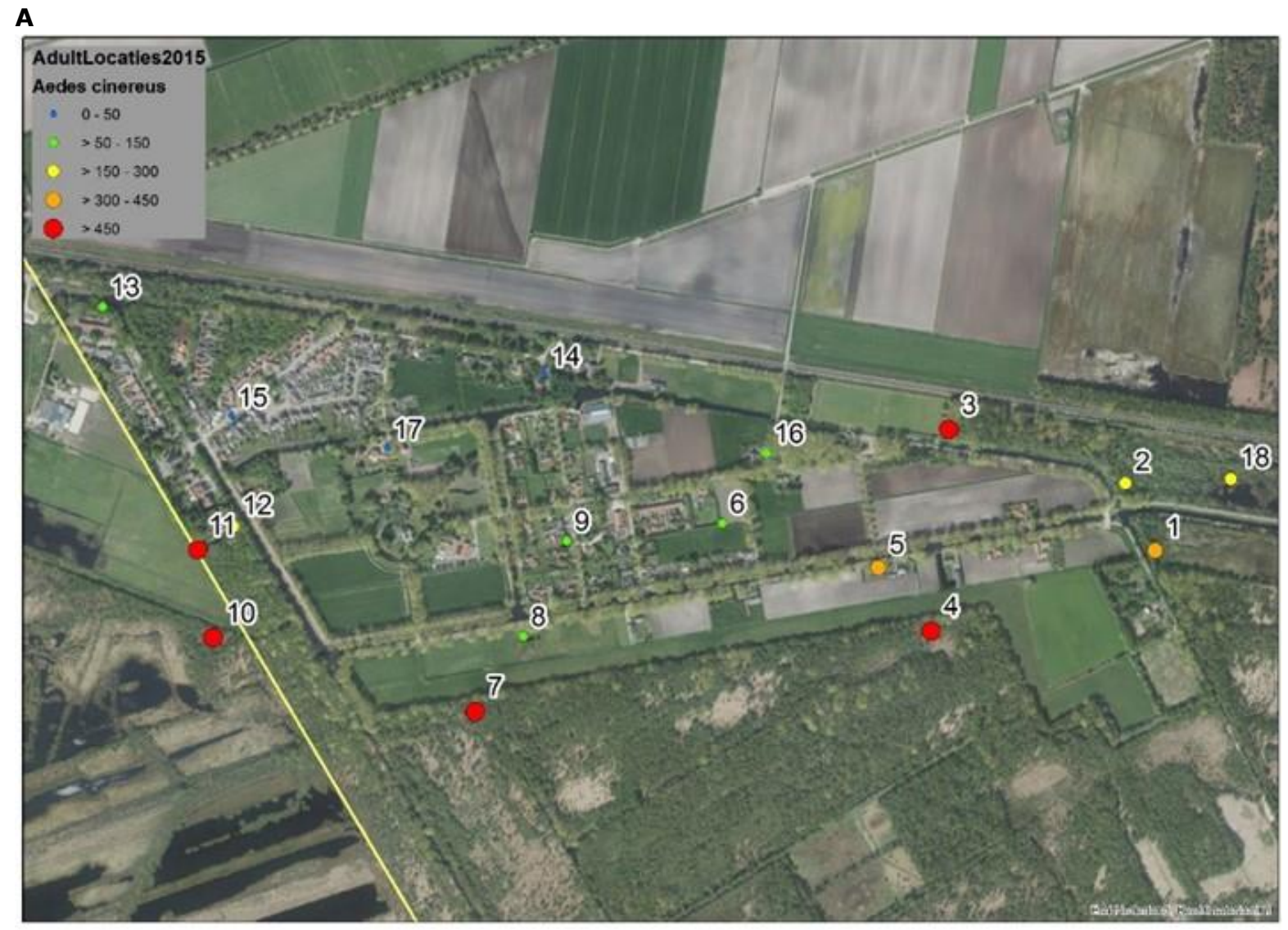

B

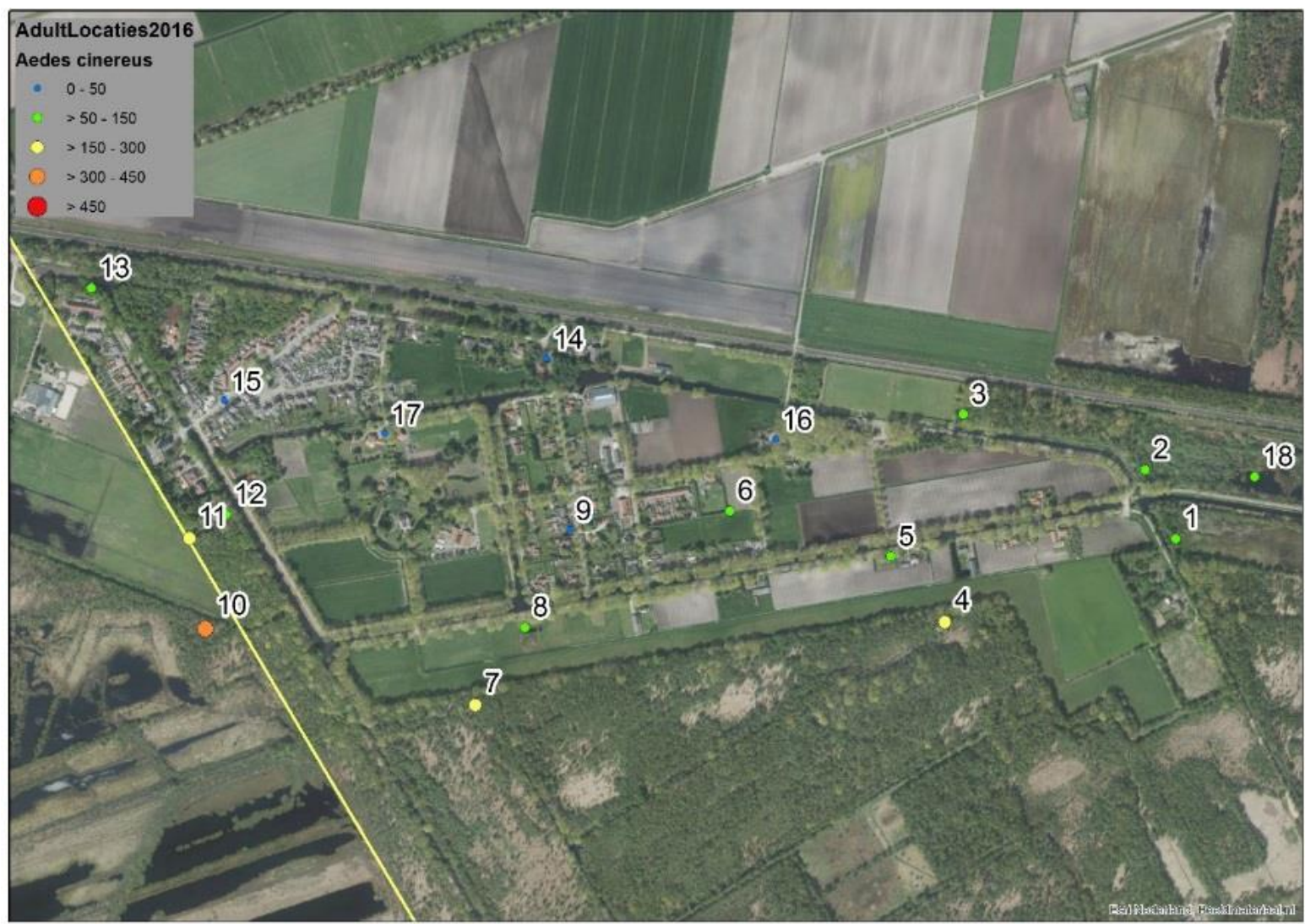



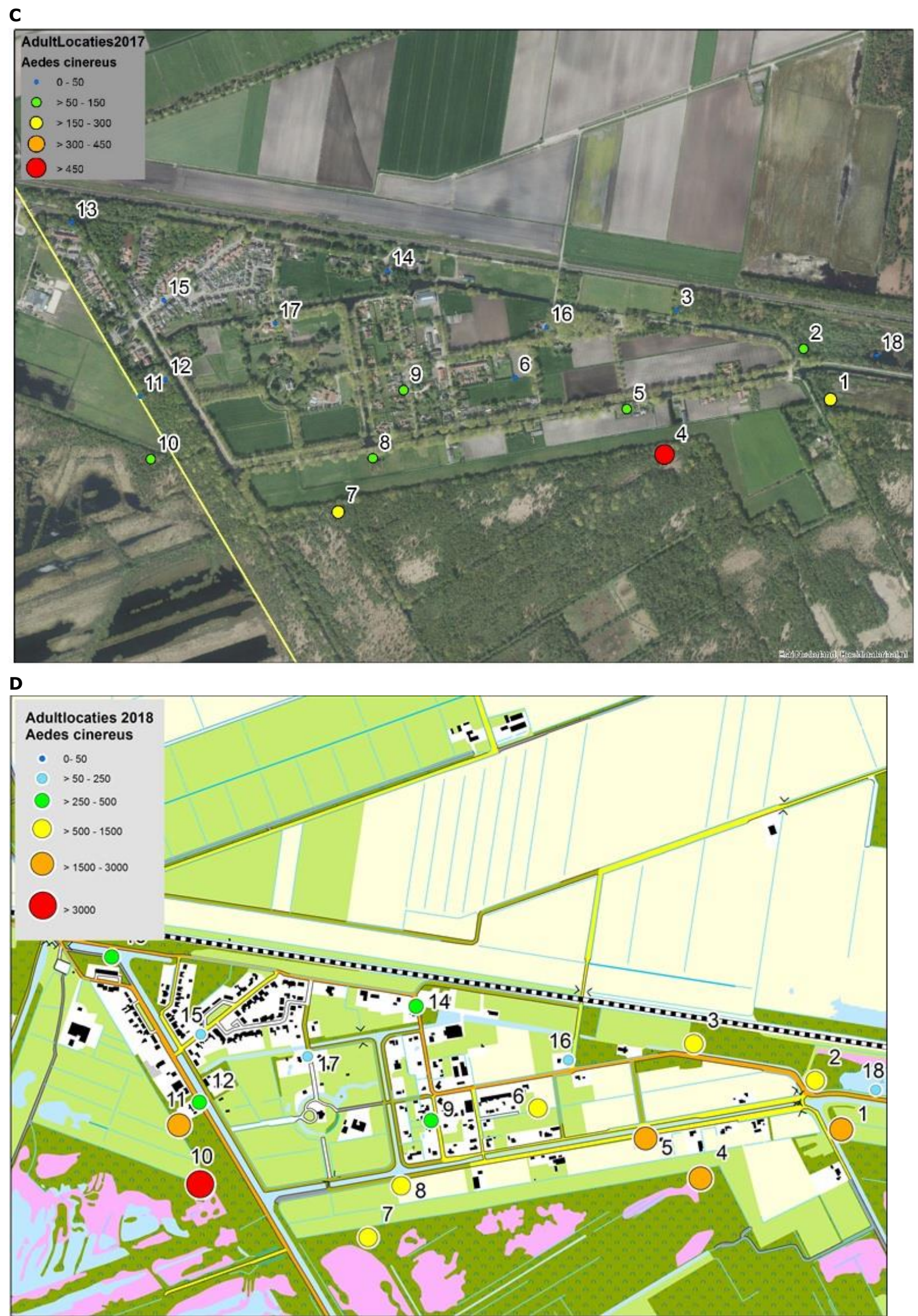

Figuur 3.15: Aantallen Aedes cinereus, uitgedrukt in aantalsklassen per locatie, in 2015 (A), 2016 (B), 2017 (C) en $2018(D)$. 
In totaal zijn in 2015 7081, in 2016 27776, in 20174457 en in 201821796 volwassen steekmuggen verzameld (Tabel 3.5). De lage aantallen in 2017 waren een gevolg dat veel permanent tijdelijke wateren na een zeer droge winter en voorjaar al in april-mei waren opgedroogd. De hoge aantallen in 2016 betroffen extreme neerslag met veel huissteekmuggen en in 2018 moerassteekmuggen door een normaal natte winter en mogelijk nattere omstandigheden in het natuurgebied.

In 2018 zijn de hogere aantallen Aedes cinereus in de oostelijke, zuidelijke en westelijke moerasgebieden duidelijk zichtbaar (Figuur 3.16A). Deze tendens van hogere aantallen aan de randen van het gebied t.o.v. het dorp zijn in alle jaren duidelijk. De overige moerassteekmuggen van het genus Ochlerotatus zijn in 2018 nauwelijks afwijkend t.o.v. voorgaande jaren met uitzondering van de locatie 6 (Dorp Oost)(Figuur 3.16B).

Het totaal aantal huissteekmuggen lag in 2018 niet hoger of lager dan in de jaren 2015 en 2017, alleen 2016 was hoog a.g.v. de extreme neerslag (Figuur 3.16C).

A

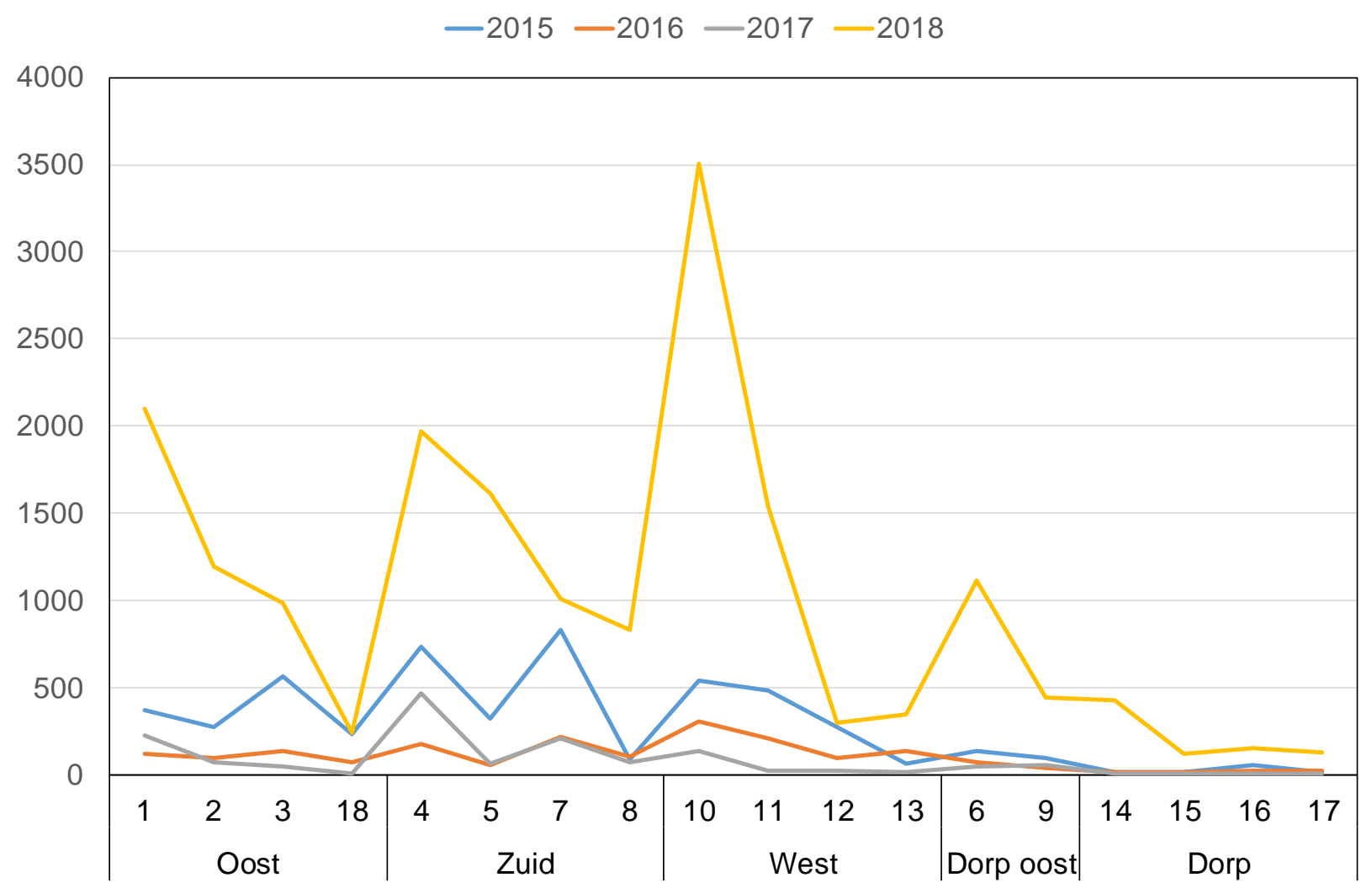


B

$-2015-2016-2017-2018$

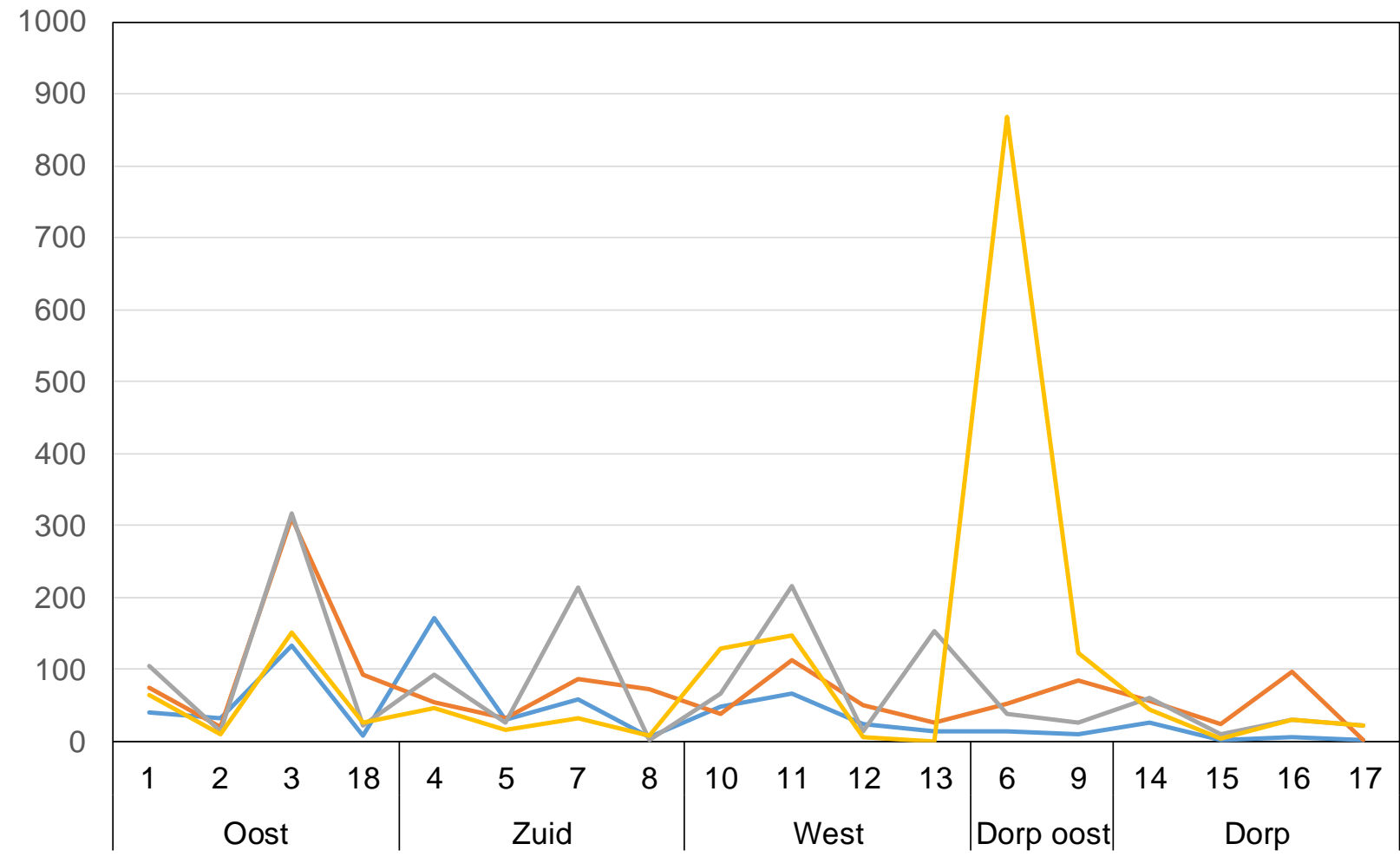

C

$-2015-2016-2017-2018$

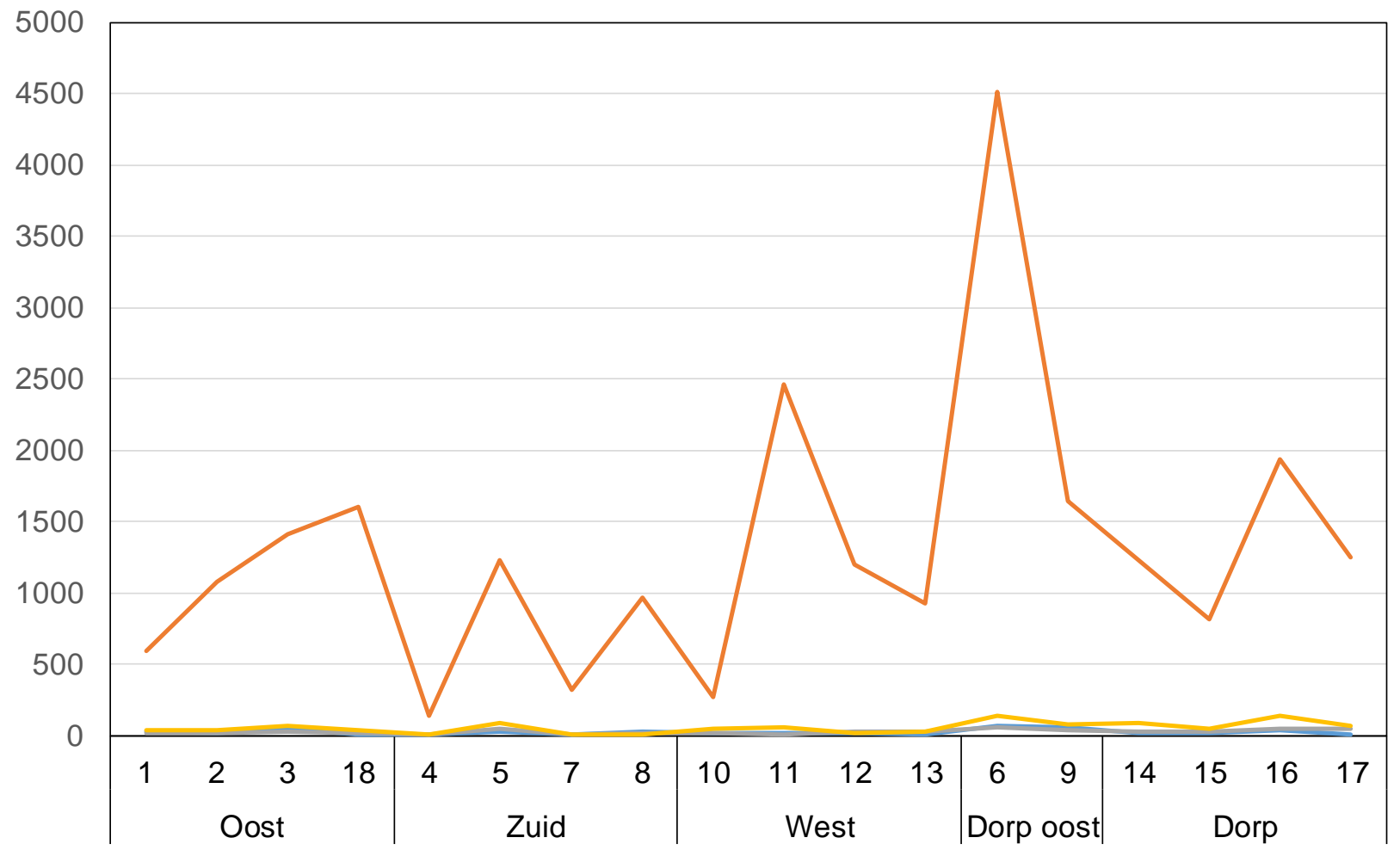

Figuur 3.16a: Aantallen steekmuggen per dominante soort/genus (A: A. cinereus, B: Ochlerotatus, C: C. pipiens) en per locatie verzameld in 2015-2018. 


\subsubsection{Volwassen knutten}

Het totaal aantal knutten verzameld over de periode 2015 tot en met 2018 laat een gestaag stijgende trend zien (Figuur 3.17). In mei-juni 2018 is het aantal knutten t.o.v. 2015 meer dan verviervoudigd.

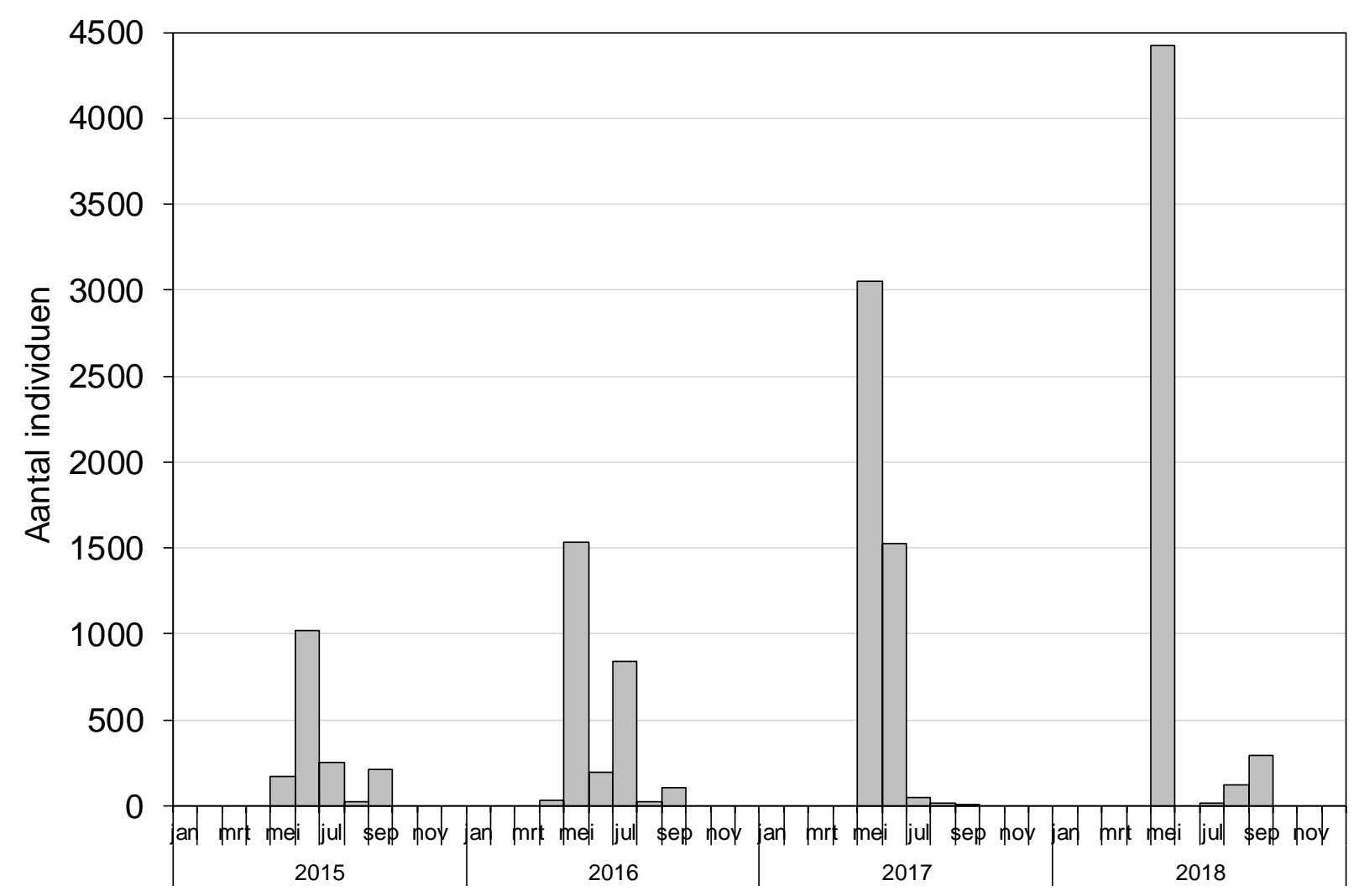

Figuur 3.17: Verdeling over de maanden van de aantallen knutten in de periode 2015-2018.

Voor een gedetailleerd overzicht van aantallen per soort wordt verwezen naar bijlage 5 . De meest dominante knutten rondom Griendtsveen behoren tot de soortgroep Culicoides impunctatus in mei en de soortgroep Culicoides gr. festivipennis en Culicoides punctatus in augustus-september (Tabel 3.7). Culicoides impunctatus leeft in drassig, zure bodems, zoals moerassen en de overgangszones aan de rand van moerassen, in vochtige en natte terrestrische habitats en in voedselarme moerassen en veenmoerassen. De habitat wordt vaak gekenmerkt door biezen zoals zomprus en veldrus, evenals de aanwezigheid van Sphagnum spp., heide en pijpenstrootje. Het grondwaterniveau is jaarrond hoog. Culicoides gr. festivipennis, de op één na meest dominante soort, heeft een voorkeur voor poelen met veel emergente planten (o.a. Typha, Juncus, Carex) in de oevers, maar kan ook voorkomen in bijna alle natte organische milieus, drassige organische gronden, weinig begroeide, slibrijke bospoelen en dergelijke.

Tabel 3.7: Aantallen knutten en verdeling van de aantallen over de soort(groep)en per vangstmoment.

\begin{tabular}{|c|c|c|c|c|c|c|c|}
\hline & Mei & Juli & & Augustus & September & Totaal & $\%$ \\
\hline Culicoides festivipennis gr. & 136 & & 11 & 103 & 229 & 479 & 9.9 \\
\hline Culicoides impunctatus gr. & 4052 & & & 1 & & 4053 & 83.6 \\
\hline Culicoides obsoletus gr. & 56 & & 4 & 1 & 16 & 77 & 1.6 \\
\hline Culicoides pallidicornis gr. & 31 & & & & & 31 & 0.6 \\
\hline Culicoides pictipennis & 29 & & & & & 29 & 0.6 \\
\hline Culicoides punctatus & 115 & & 2 & 15 & 47 & 179 & 3.7 \\
\hline Culicoides salinarius & & & & & 1 & 1 & 0.0 \\
\hline Totaal & 4419 & & 17 & 120 & 293 & 4849 & \\
\hline
\end{tabular}


Het hoogste aantal knutten is gevonden in het dorp oost (locatie huis 6), gevolgd door een locatie in de randzone aan de westzijde van het dorp in de (locatie veld 11) (Tabel 3.8). Beide locatie liggen nabij tuincomposthopen.

Tabel 3.8: Aantallen knutten per soort en per locatie verzameld in 2018.

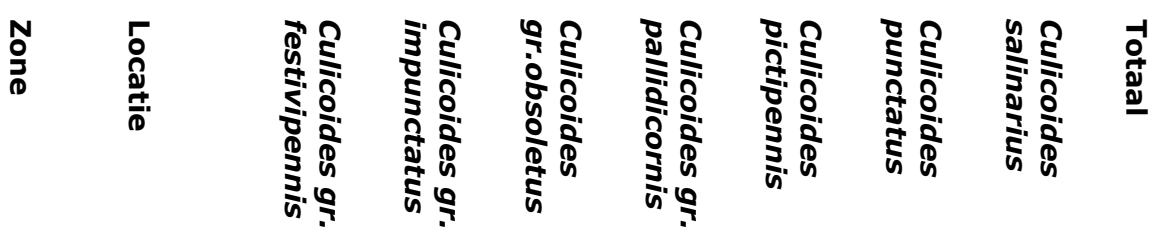

\begin{tabular}{|c|c|c|c|c|c|c|c|c|c|}
\hline Oost & veld 1 & 229 & 31 & 1 & 2 & 8 & 57 & & 328 \\
\hline Oost & veld 2 & 26 & 24 & 1 & & 4 & 48 & & 103 \\
\hline Oost & veld 3 & 20 & 60 & 24 & 8 & & 19 & & 131 \\
\hline Oost & huis 18 & 2 & 2 & & & 4 & 6 & & 14 \\
\hline Zuid & veld 4 & 39 & 168 & 1 & & & 10 & & 218 \\
\hline Zuid & veld 5 & & & & & & & & \\
\hline Zuid & veld 7 & 5 & 52 & 2 & & & 2 & & 61 \\
\hline Zuid & veld 8 & 2 & 4 & & & & 12 & & 18 \\
\hline West & veld 10 & & 96 & & & & & & 96 \\
\hline West & veld 11 & 46 & 1024 & 9 & 16 & 12 & 3 & & 1110 \\
\hline West & huis 12 & 22 & 28 & & 1 & & 1 & & 52 \\
\hline West & huis 13 & 3 & & & & & 1 & & 4 \\
\hline Dorp oost & huis 6 & 9 & 2540 & 35 & 4 & & 16 & & 2604 \\
\hline Dorp oost & huis 9 & 3 & 1 & & & & & & 4 \\
\hline Dorp & huis 14 & 50 & & 2 & & & 1 & & 53 \\
\hline Dorp & huis 15 & 1 & 23 & & & 1 & & & 25 \\
\hline Dorp & huis 16 & 15 & & 2 & & & 3 & 1 & 21 \\
\hline \multirow[t]{2}{*}{ Dorp } & huis 17 & 7 & & & & & & & 7 \\
\hline & & 479 & 4053 & 77 & 31 & 29 & 179 & 1 & 4849 \\
\hline
\end{tabular}

C. impunctatus gr. blijkt al jaren talrijk op te treden in mei. De aantallen zijn vanaf 2015 steeds toegenomen (Figuur 3.18A). De verdeling over het gebied varieert van talrijk in oost 18 in 2015-2016, dorp oost 6 in 2015 en west 11 2016, naar talrijk in west 11 in 2017-2018 en zuid 7 in 2017 en dorp oost 6 in 2018 (Tabel 3.9). Culicoides festivipennis gr. en C. punctatus hebben een minder duidelijk tijdsgebonden optreden en waren in 2018 vooral talrijk in juni respectievelijk juli (Figuur 3.18B en C). 
A

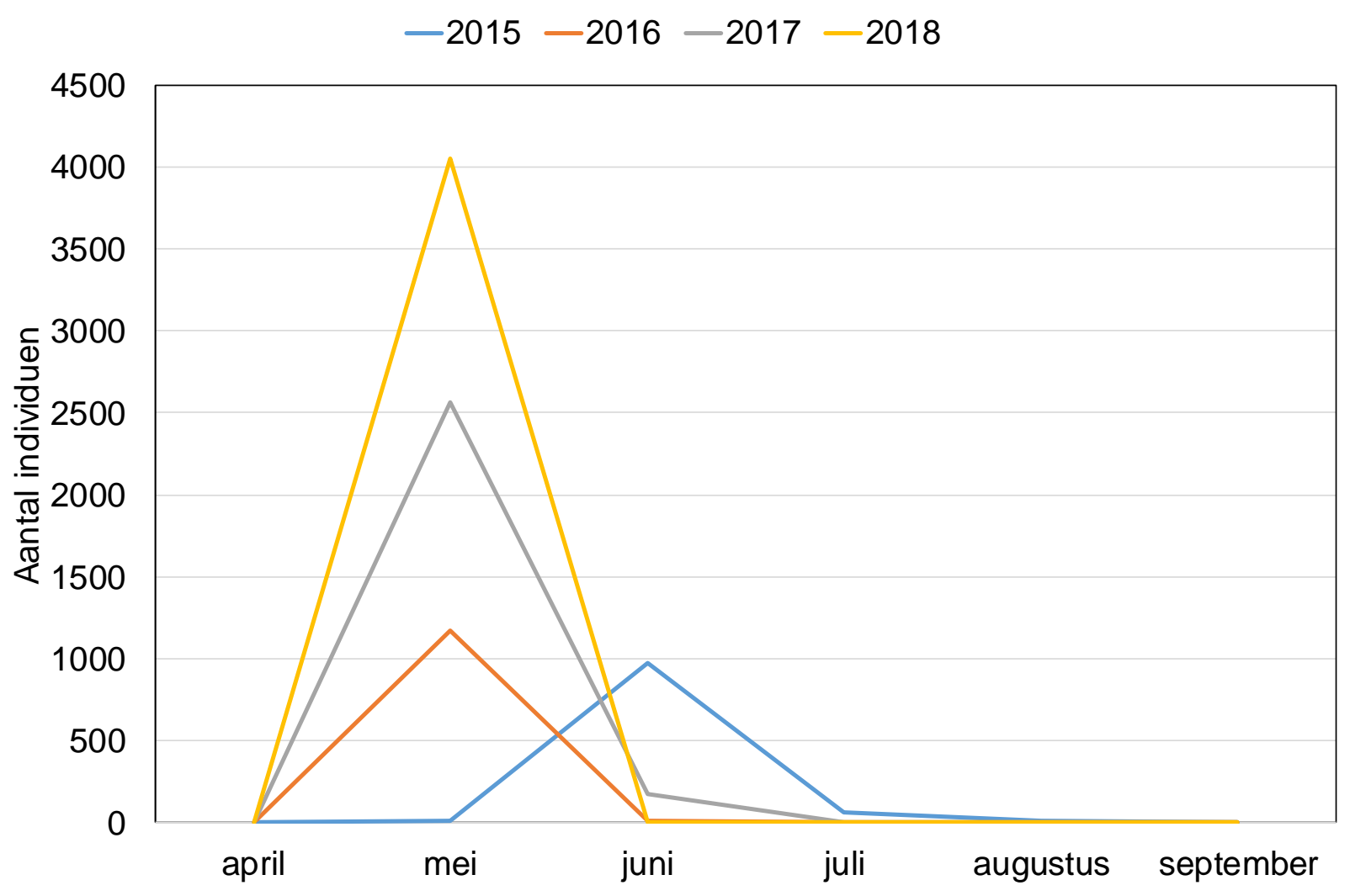

B

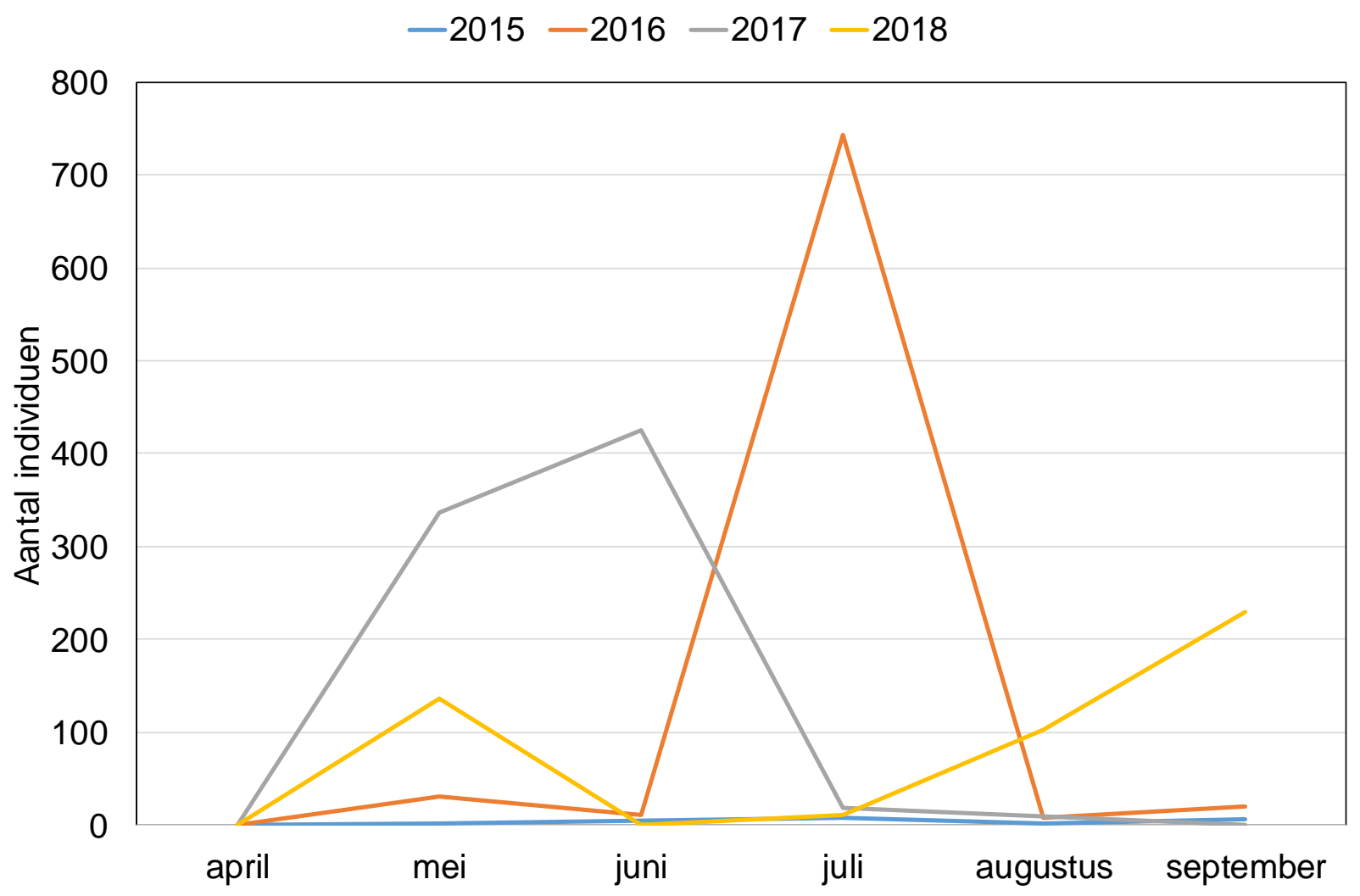


C

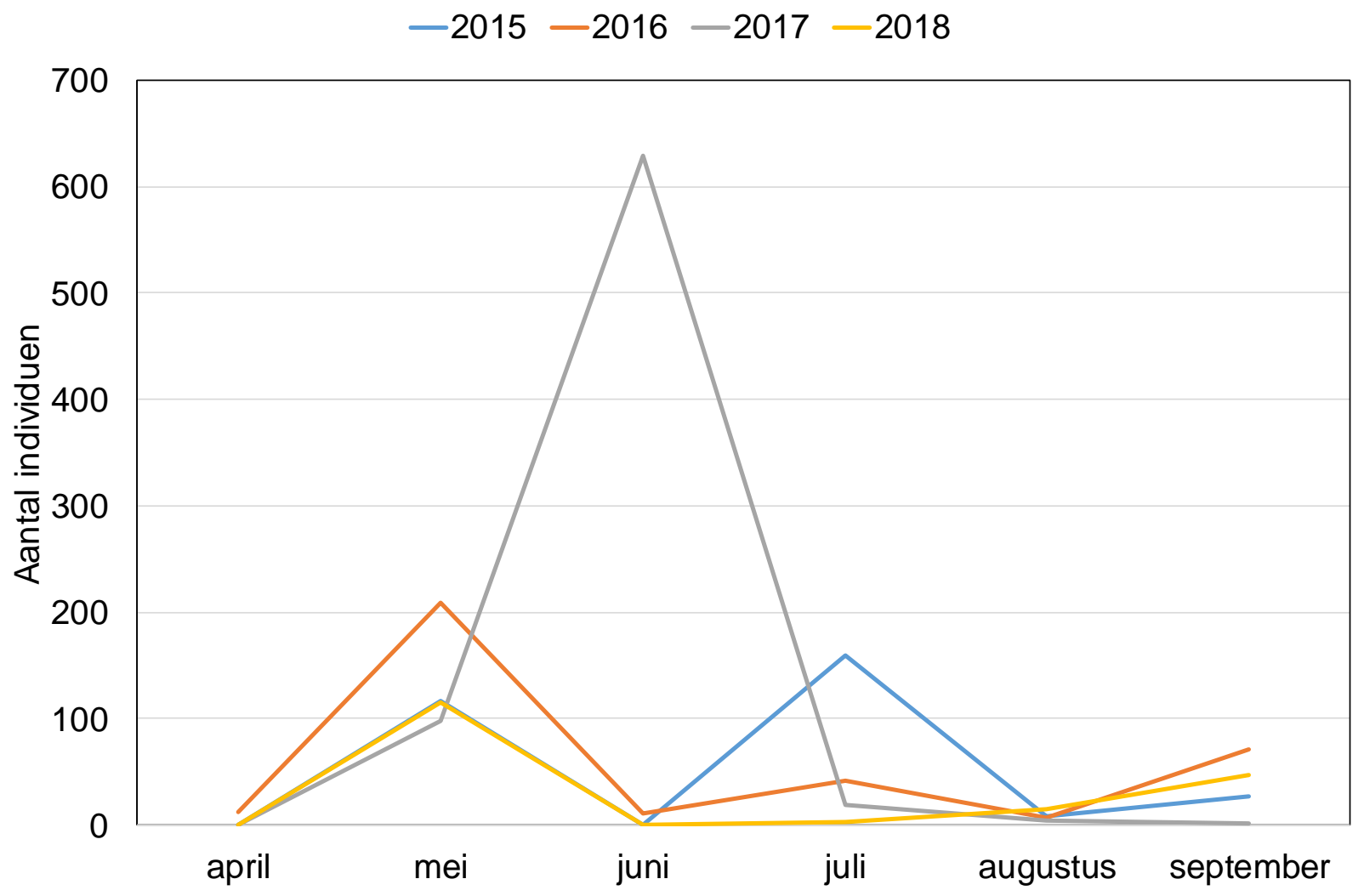

Figuur 3.18: Aantallen knutten per soort verzameld in 2015-2018 (A: Culicoides impunctatus gr., B: Culicoides festivipennis gr., C: Culicoides punctatus).

Tabel 3.9: Het voorkomen van Culicoides impunctatus gr. per jaar naar vanglocatie.

\begin{tabular}{lrrrrr}
\hline Zone & Locatie & $\mathbf{2 0 1 5}$ & $\mathbf{2 0 1 6}$ & $\mathbf{2 0 1 7}$ & $\mathbf{2 0 1 8}$ \\
\hline oost & 1 & 15 & 63 & 16 & 31 \\
oost & 2 & 31 & 2 & 25 & 24 \\
oost & 3 & 132 & 60 & 32 & 60 \\
oost & 18 & 279 & 113 & 1 & 2 \\
zuid & 4 & 16 & 7 & 13 & 168 \\
zuid & 5 & 4 & 58 & 53 & \\
zuid & 7 & 26 & 63 & 1100 & 52 \\
zuid & 8 & 6 & 30 & 63 & 4 \\
west & 10 & 14 & 24 & 226 & 96 \\
west & 11 & 43 & 9 & 324 & 1024 \\
west & 12 & 38 & 580 & 129 & 28 \\
west & 13 & 73 & 6 & 48 & \\
dorp oost & 6 & 271 & 92 & 68 & 2540 \\
dorp oost & 9 & 65 & 40 & 144 & 1 \\
dorp & 14 & 9 & 13 & 194 & \\
dorp & 15 & 13 & 7 & 76 & 23 \\
dorp & 16 & 0 & 11 & 10 & \\
dorp & 17 & 4 & 0 & 213 & \\
\hline
\end{tabular}




\section{Discussie en conclusies}

\subsection{Larven van steekmuggen}

De inventarisatie in 2016 leverde 4 kleinere gebiedsdelen op met hoge aantallen steekmuglarven. Daarnaast kwamen larven verspreid door het gebied voor met enkele kleine gebiedsdelen veel verder van het dorp die ook als broedgebied fungeren maar waarvan de kans dat de volwassen dieren het dorp bereiken kleiner is. In april-mei 2017 is de inventarisatie van 2016 herhaald. Hieruit bleek dat 60\% van de locaties met larven in 2016 water bevatte en slechts $23 \%$ ook bezet was met larven. De ligging van deze locaties en daarmee ook van de larven van de moerassteekmug $A$. cinereus, laat zien dat deze over het gehele zoekgebied verspreid zijn. De hoogste aantallen zijn opnieuw op de locaties gevonden die in 2016 als hotspot waren aangemerkt met de aantekening dat op twee hotspots de aantallen relatief lager waren maar relatief hoog t.o.v. de overige vaak droge locaties in het gebied. Er zijn in 2018 in de daaropvolgende maanden systematisch steekproeven genomen op een aantal geselecteerde locaties om te zien 1) of locaties weer water gingen bevatten en 2) of er meerdere generaties ontwikkelen. Droge locaties vulden zich echter niet meer op met water. Hierdoor was een tweede gebiedsdekkende dipronde in 2018 niet zinvol. De moerassteekmuggen Ochlerotatus cantans en Aedes cinereus bleken ook in juli als larf voor te komen. Dit duidt erop dat beide soorten meerdere generaties per jaar kunnen doorlopen wanneer het gebied habitat biedt. In 2018 herhaalde zich het beeld van 2017 met als bijzonderheid dat na mei geen extra ontwikkeling kon optreden door de aanhoudende droogte. Klimatologisch heeft de droogte een groter effect (op de gemeten aantallen) dan een natte zomer omdat het gebied zelf ook vernat door genomen en te nemen maatregelen.

Het verloop van de ontwikkeling van larven van steekmuggen is duidelijk gebonden aan het optreden van langdurig tijdelijke wateren in het gebied. In dergelijke wateren kunnen bij voldoende waterhoudendheid ook in de zomer nog steekmuggen ontwikkelen. Daarnaast was 2017 een droog en 2018 een nog droger jaar waarbij al vroeg in het voorjaar veel potentiële tijdelijke wateren droog stonden.

\subsection{Volwassen steekmuggen}

Het patroon van ontwikkeling van volwassen steekmuggen in 2018 liet, vergelijkbaar met 2017, een 'klassiek' beeld van een moerassteekmuggenpopulatie zien met hoge aantallen in het voorjaar die daarna snel uitdoven. Door de aanhoudende droogte na mei trad additioneel geen ontwikkeling van steekmuggen meer op. Het klassieke beeld van het optreden van volwassen moerassteekmuggen is een gevolg van het opdrogen van tijdelijke wateren in het gebied in het voorjaar. De in totaal lagere aantallen in het gehele gebied en de beperking van deze aantallen tot de maand mei hebben ertoe geleid dat in het dorp Griendtsveen in 2018 na mei geen overlast is ervaren. De hoge aantallen in mei 2018 zijn echter wel korte tijd als overlast ervaren (mond. med. bewoners). Dit beeld past bij de aantallen en het weer in de tweede helft van de meimaand.

Bij het vergelijken van de moerassteekmuggenpopulaties tussen 2015, 2016, 2017 en 2018 valt op dat de populaties in 2015 niet te relateren zijn aan de weersomstandigheden en vooral de neerslag terwijl dat in 2016, 2017 en ten dele 2018 wel het geval is. In 2015 was het gebied in de nabijheid van het dorp waarschijnlijk natter dan in de twee jaren daarna. In 2018 kan de lekkende kade een additionele rol hebben gespeeld. De oorzaak in 2015 kan hebben gelegen in nattere voorgaande jaren of (al dan niet in combinatie met) hogere peilen.

Meer in detail trad tussen 2015-2017 een afname van de aantallen van de soort $A$. cinereus op en namen de aantallen van de soort $O$. punctor in het gebied toe terwijl $A$. cinereus in 2018 weer domineerde. $A$. cinereus is een meer tolerante soort met een breder habitatspectrum terwijl $O$. punctor een zuurminnende soort is die vaker op koelere, beschaduwde, tijdelijk water bevattende locaties voorkomt. Ook is $O$. punctor een vroege voorjaarssoort en meer typisch voor hoogveengebieden.

Huissteekmuggen waren zeer talrijk na de extreme neerslag in 2016 , voor het overige spelen ze alleen lokaal een rol maar veroorzaken in dit gebied geen overlast. De plantenboorsteekmuggen ontwikkelden zich alleen in 2017 iets talrijker en waren vrij laag in aantal in 2018. 
De verdeling van de aantallen over de jaren 2015, 2016, 2017 en 2018 naar zone rondom en in het dorp laat zien dat er tussen 2015-2018 ieder jaar een afname van de aantallen optrad in de richting van de dorpskern. Met andere woorden in de kern van het dorp is het aantal met sterke spreiding circa $30 \%$ van de aantallen aan de rand. De oost- en zuidrand herbergden de hoogste aantallen en de westrand en dorp oost waren lager in 2015-2017 terwijl in 2018 een verschuiving optrad van hogere aantallen naar het zuidoosten en het westen. De aantallen zijn niet jaarlijks op precies dezelfde locatie het hoogst wat aangeeft dat de verspreiding van de individuen enige variatie vertoont mogelijk deels samenhangend met de ligging van de langdurig tijdelijke wateren.

\subsection{Volwassen knutten}

Het totaal aantal knutten verzameld over de periode 2015 tot en met 2018 laat per jaar een gestaag stijgende trend zien. In de maanden mei-juni van 2018 is het aantal knutten t.o.v. 2015 meer dan verviervoudigd. Dominant is de moerassoortgroep Culicoides gr. impunctatus, en redelijk aanwezig zijn een soortengroep van poelen Culicoides gr. festivipennis en een soort van natte graslanden Culicoides punctatus. C. impunctatus was in 2018 vooral aanwezig in de westrand en in het dorp aan de zuidoostzijde. Waarschijnlijk is het voorkomen gerelateerd aan drassige moerasmilieus en het natter zijn in het vroege voorjaar van de Deurnsche Peel of door interne gebiedseffecten. Na eind mei tot half juni verminderden de aantallen in 2018 door de droogte maar dit kan ook samenhangen met het natuurlijke populatieverloop.

\subsection{Conclusies en aanbevelingen}

In 2015, het eerste jaar van onderzoek, is vastgesteld dat de door de bewoners van Griendtsveen gesignaleerde overlast van steekmuggen reëel is. De overlast werd veroorzaakt door moerassteekmuggen (voornamelijk de soort Aedes cinereus), die afkomstig zijn uit de Mariapeel, de Deurnsche Peel, het Kanaalbos en het Grauwveen. De larven van deze moerassteekmug ontwikkelen zich in langdurig water bevattende tijdelijke wateren en de volwassen dieren verspreiden zich na het uitvliegen over de omgeving, onder andere in de richting van het dorp.

Uit de onderzoeken verricht in de jaren daarna (2016-2018) is gebleken dat twee milieufactoren de ontwikkeling van deze soort bepalen:

1. De weersomstandigheden.

2. De gewijzigde en (geleidelijk) wijzigende hydrologische omstandigheden in de natuur/moerasgebieden die het dorp omringen.

Beide milieufactoren bepalen in samenhang of de in het moerasgebied aanwezige droogvallende depressies langdurig gevuld zijn met water of niet. De weersomstandigheden verschillen van jaar tot jaar, zoals de extreme verschillen tussen de natte zomermaanden in 2016 en de droogte in 2018. Beide hebben grote effecten op de steekmuggenpopulaties laten zien.

Een derde milieufactor is de 'structuur' van het gebied zelf. De hoogte, bodemsamenstelling, vegetatie en terreinaccidentatie kan sterk verschillen. Deze combinatie in omstandigheden kan lokaal leiden tot langdurig tijdelijke wateren, zoals is gebleken voor vier deelgebiedjes aangeduid als 'hotspots'. Voor deze deelgebiedjes die drager waren van hogere aantallen steekmuggen zijn apart maatregelen voorgesteld.

Voor de toekomstige inrichting en het beheer van het moerasgebied betekent dit dat ingespeeld moet gaan worden op extreme weersomstandigheden door in te grijpen op de hydrologische omstandigheden in samenhang met de 'structuur 'van het gebied omdat het weer zelf niet stuurbaar is. Het belangrijkste doel in het gebied is het stabiel nat houden van het moeras. Stabiel nat houden betekent het zoveel mogelijk op peil houden van oppervlaktewater in het gebied en het zoveel mogelijk aan maaiveld houden van het grondwater in het gebied. Daarmee wordt droogval zoveel mogelijk voorkomen en dat leidt op haar beurt weer tot een vermindering van de kans op overlast door steekmuggen.

Om dit te bereiken is het nodig dat de grond- en oppervlaktewaterpeilen in het gebied met dit doel in het achterhoofd beheerd gaan worden. Bij een teveel aan water is dat vaak geen probleem maar bij een tekort aan water kan dat wel zo zijn. Om tekorten te voorkomen is het nodig dat er een (grond)watervoorraad beschikbaar is zoals vasthouden in de bodem (mogelijk van bufferzones) en bergen op bestaand oppervlaktewater (plassen en wijken). Dergelijk beheer is vooral van belang in de zones die grenzen aan het dorp. Hoe ver de steekmuggen zich vanuit het gebied tot in het dorp kunnen verspreiden is onbekend. Wel weten we nu dat de afname vanaf de rand tot in de kern van het dorp over enkele honderden meter 
groot is. Bij de inrichting is het daarom van belang juist de compartimenten in de randzone zo te beheren dat ze of langdurig (vanaf vroeg in het voorjaar) droog zijn of juist nat blijven. Een voorbeeld is de afwatering door de slenk van compartiment XIV naar XV waar de inrichting en het onderhoud zorgvuldig gericht moet zijn op het onder maaiveld houden van het water na het vroege voorjaar en eventueel achterblijvende restpoelen voorkomen worden door maaibeheer. Monitoring van de condities is nodig om deze werking te verfijnen en handhaven.

Het gebied Mariapeel is nog volop in ontwikkeling. De uitvoering van het peilbeheer in de Mariapeel en vraagstukken rondom de nog steeds zeer wisselende waterhuishouding in het Kanaalbos en zuidelijk daarvan gelegen gebiedsdelen leiden tot veranderingen of verdienen aandacht. Ook gaan aan de westzijde door de inrichting van Leegveld mogelijk veranderingen in de Deurnsche Peel plaats vinden. De interne en externe ontwikkeling zijn aanleiding tot de verwachting dat mogelijke overlast op steekmuggen in het dorp voorlopig blijft bestaan. De aantallen steekmuggen zijn een goede graadmeter voor de mate van stabilisering van de waterhuishouding. Daarom wordt aanbevolen om het monitoren van volwassen steekmuggen de komende jaren voort te zetten. Jaarlijks kan geadviseerd worden over effecten van maatregelen of voorstellen voor aanvullende maatregelen (of bijsturing). Het monitoren van larven is afhankelijk van de vraag of doorgegaan wenst te worden met het lokaliseren van bronnen van overlast of dat de aandacht vooral uitgaat naar overall effecten van de ingezette ontwikkelingen in het gehele gebied.

Het aantal knutten is over de periode 2015 tot en met 2018 per jaar gestegen. Waarschijnlijk is deze toename een gevolg van een toename van natte en drassige moerasmilieus, vooral natter tot later in het voorjaar. De toename kan tijdelijk zijn en opgetreden door veranderingen in het gebied maar kan ook aanhouden. Hier spelen twee vragen. Ten eerste wordt er in de periode half mei-half juni overlast van knutten ervaren in het dorp? Ten tweede is de knuttentoename tijdelijk of permanent en waar stabiliseren de aantallen zich? Hiervoor is het nodig dat de komende jaren knutten tegelijk met de volwassen steekmuggen gemonitord blijven. 


\section{Bijlagen}

Bijlage 1: Overzicht van de meetlocaties met $x$ - en $y$-coördinaten in en rondom Griendtsveen

\begin{tabular}{|c|c|c|c|c|}
\hline \multicolumn{2}{|l|}{ Locatie } & \multicolumn{2}{|c|}{ Coördinaten } & \multirow{2}{*}{ Omschrijving } \\
\hline nummer & zone & $\mathbf{x}$ & $\mathbf{Y}$ & \\
\hline 1 & moerasgebied oost & 191.006 & 383.687 & rand moerasbos \\
\hline 2 & moerasgebied oost & 190.938 & 383.816 & rand moerasbos \\
\hline 3 & moerasgebied oost & 190.618 & 383.913 & droog bos tussen struiken \\
\hline 4 & moerasgebied zuid & 190.635 & 383.558 & overgang droog naar nat bos \\
\hline 5 & moerasgebied zuid & 190.490 & 383.663 & onder struiken rand van tuin \\
\hline 6 & dorp oost & 190.207 & 383.743 & onder struiken rand van tuin \\
\hline 7 & moerasgebied zuid & 189.759 & 383.402 & overgang droog naar nat bos \\
\hline 8 & moerasgebied zuid & 189.846 & 383.538 & in ruigte onder coniferenhaag \\
\hline 9 & dorp & 189.925 & 383.711 & $\begin{array}{l}\text { naast haag en onder } \\
\text { kamperfoelie }\end{array}$ \\
\hline 10 & moerasgebied west & 189.316 & 383.543 & rand moerasbos \\
\hline 11 & moerasgebied west & 189.260 & 383.698 & $\begin{array}{l}\text { rand sloot, weiland en droog } \\
\text { bos }\end{array}$ \\
\hline 12 & moerasgebied west & 189.314 & 383.759 & onder struiken van tuin \\
\hline 13 & moerasgebied west & 189.083 & 384.142 & $\begin{array}{l}\text { tussen struiken bij rand van } \\
\text { tuin }\end{array}$ \\
\hline 14 & dorp & 189.885 & 384.012 & onder struiken \\
\hline 15 & dorp & 189.317 & 383.938 & onder struiken in voortuin \\
\hline 16 & dorp oost & 190.287 & 383.870 & onder struiken in voortuin \\
\hline 17 & dorp & 189.599 & 383.880 & tussen struiken in voortuin \\
\hline 18 & moerasgebied oost & 193.020 & 383.550 & rand moerasbos \\
\hline
\end{tabular}


Bijlage 2: $\quad$ Milieukenmerken van de meetlocaties

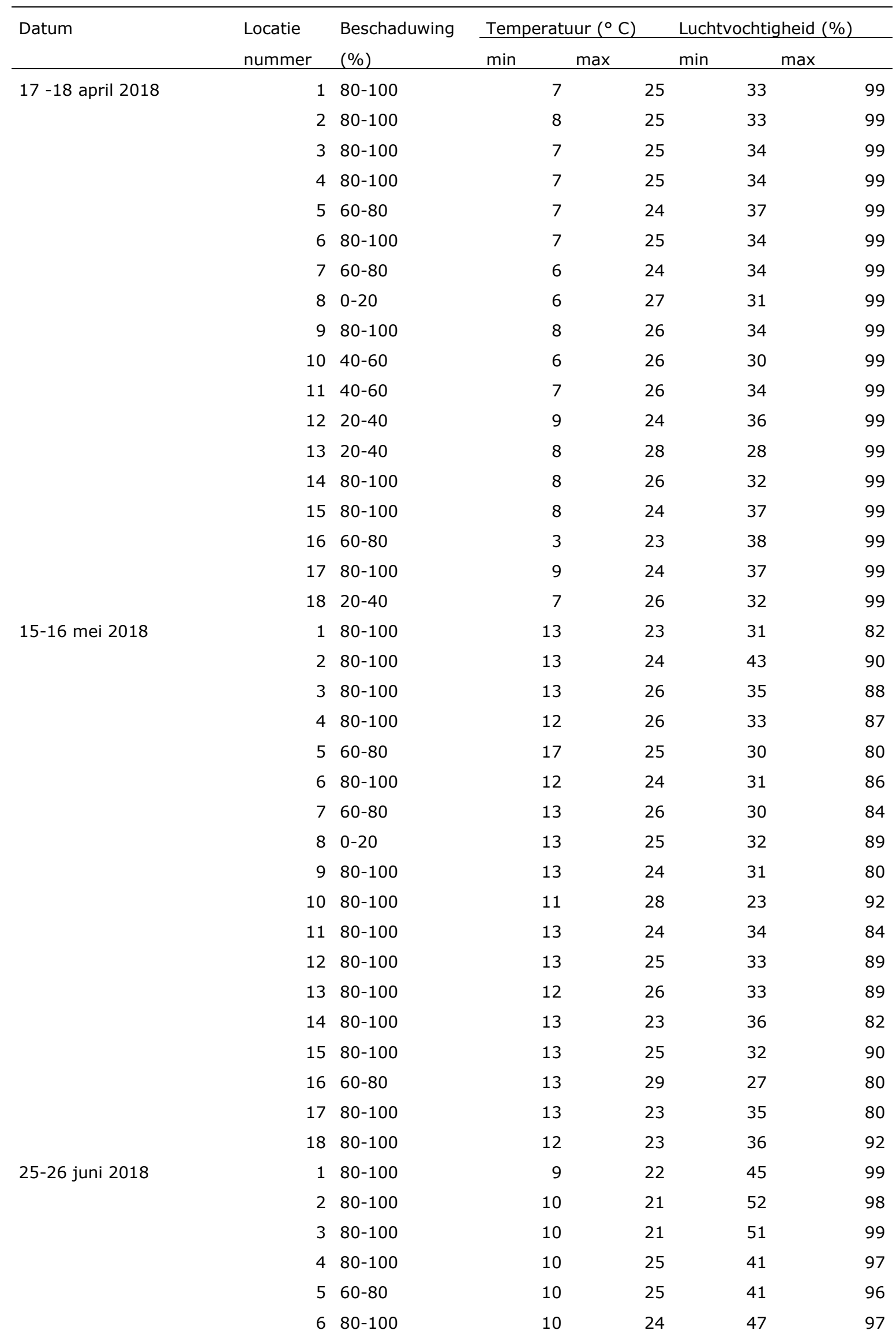




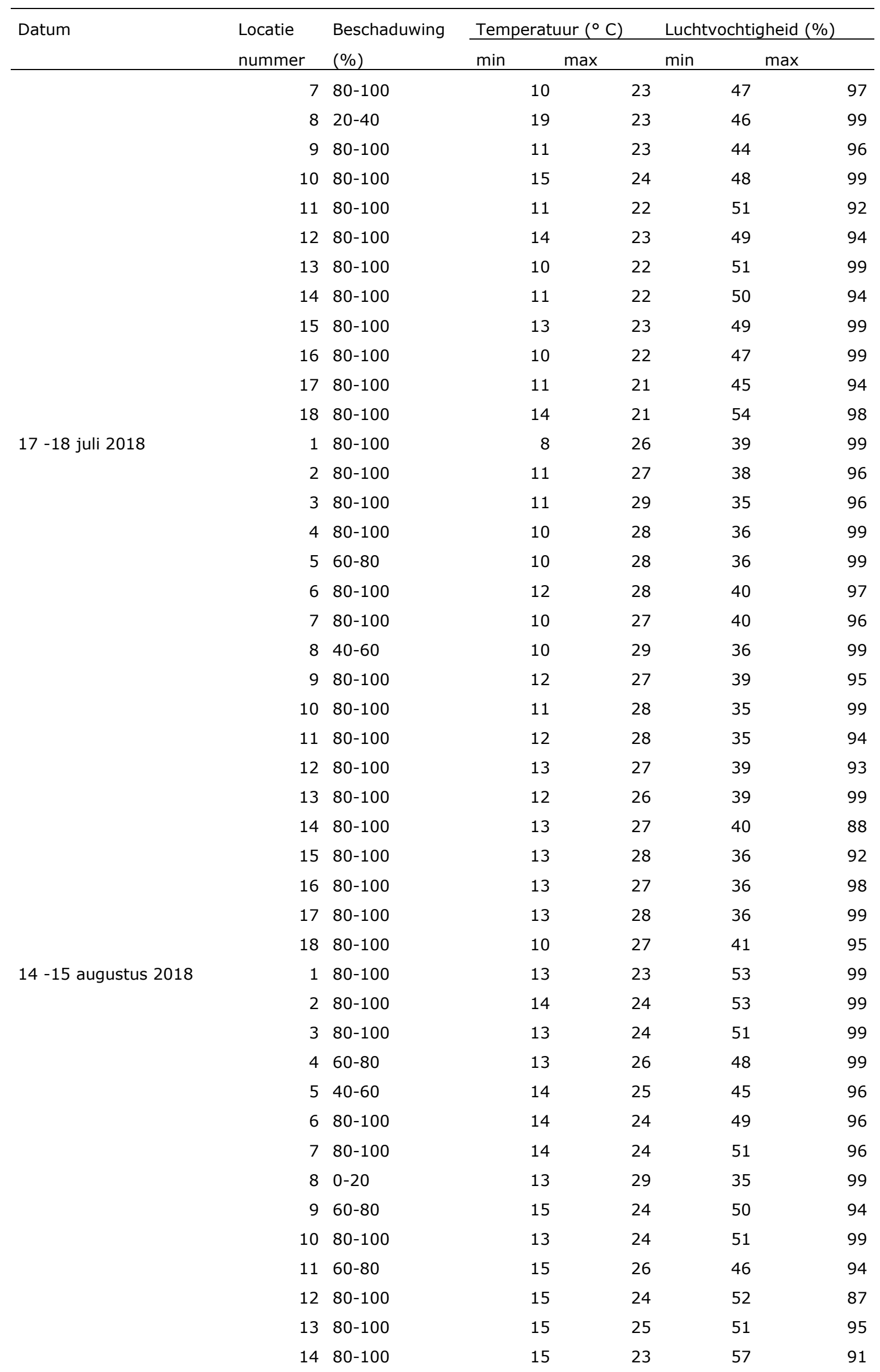




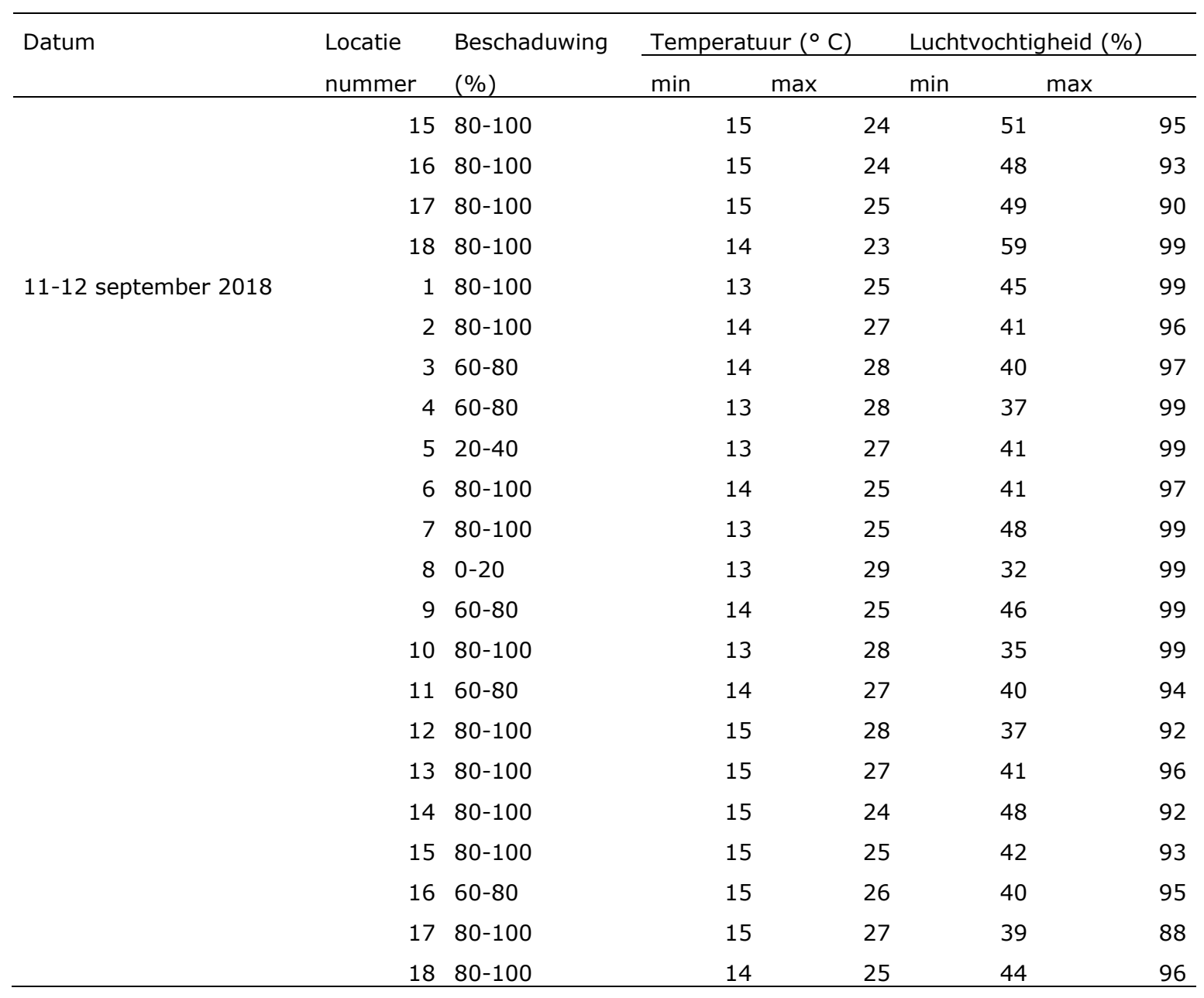


Bijlage 3: Overzicht van gegevens van de diplocaties.

\begin{tabular}{|c|c|c|c|c|c|c|c|c|c|c|c|c|c|c|c|c|}
\hline $\mathrm{Nr}$ & Datum & $x$ & $\mathbf{Y}$ & $\begin{array}{l}\text { Water- } \\
\text { diepte }\end{array}$ & $\begin{array}{l}\text { VegType } \\
\text { Onder1 }\end{array}$ & $\begin{array}{l}\text { VegType } \\
\text { Onder2 }\end{array}$ & $\begin{array}{l}\text { VegType } \\
\text { Boven }\end{array}$ & $\begin{array}{l}\text { Bescha- } \\
\text { duwing }\end{array}$ & $\begin{array}{l}\text { Aantal } \\
\text { Dips }\end{array}$ & Permanentie & OppNat & Lengte & Breedte & $\begin{array}{l}\text { Obs- } \\
\text { Adult }\end{array}$ & Foto & Opmerking \\
\hline 1 & 1 mei 2018 & 190995 & 383694 & enkeldiep & geen/water & & wilgen & gesloten & 0 & permanent nat & $0.5-0.75$ & 10 & 10 & 0 & oude val-2 & \\
\hline 2 & 1 mei 2018 & 191075 & 383674 & laarsdiep & $\begin{array}{l}\text { gras met } \\
\text { pitrus }\end{array}$ & & & open & 0 & nu nat & 0.5 & 400 & 40 & 0 & 2 & \\
\hline 3 & 1 mei 2018 & 191071 & 383656 & laarsdiep & ouwe wijk & & bomenrij & halfopen & 0 & nu nat & 1 & 400 & 1 & 0 & 4 & \\
\hline 4 & 1 mei 2018 & 193126 & 383640 & laarsdiep & $\begin{array}{l}\text { gras met } \\
\text { pitrus }\end{array}$ & & & open & 0 & permanent nat & 1 & 400 & 40 & 0 & 2 & \\
\hline 5 & 1 mei 2018 & 191269 & 383608 & laarsdiep & pijpestrootje & flap & wilgen & halfopen & 0 & nu nat & 0.75 & 200 & 20 & 0 & 3 & \\
\hline 6 & 1 mei 2018 & 191199 & 383569 & droog & pijpestrootje & & berken & gesloten & -1 & $\begin{array}{l}\text { permanent } \\
\text { droog }\end{array}$ & 0 & 400 & 20 & 0 & 1 & \\
\hline 7 & 1 mei 2018 & 191233 & 383529 & enkeldiep & geen/water & & elzen & gesloten & 3 & nu nat & 1 & 20 & 3 & 0 & 1 & \\
\hline 8 & 1 mei 2018 & 191217 & 383455 & laarsdiep & pijpestrootje & & berken & halfopen & 5 & $\begin{array}{l}\text { nu nat / } \\
\text { permanent ? }\end{array}$ & 0.05 & 200 & 20 & 0 & 2 & \\
\hline 9 & 1 mei 2018 & 191358 & 383412 & kniediep & pijpestrootje & flap & berken & halfopen & 0 & $\begin{array}{l}\text { nu nat / } \\
\text { permanent? }\end{array}$ & 0.75 & 400 & 40 & 0 & 2 & \\
\hline 10 & 1 mei 2018 & 191301 & 383264 & enkeldiep & pijpestrootje & & berken & halfopen & 1 & nu nat & 0.05 & 40 & 100 & 0 & 2 & \\
\hline 11 & 1 mei 2018 & 191179 & 383400 & enkeldiep & pijpestrootje & & wilgenbos & halfopen & 0 & nu nat & 0.25 & 40 & 40 & enkele & 1 & \\
\hline 12 & 1 mei 2018 & 191158 & 383390 & enkeldiep & $\begin{array}{l}\text { pijpestrootje } \\
\text { ruigte }\end{array}$ & & berken & gesloten & 0 & nu nat & 1 & 10 & 20 & 0 & 1 & \\
\hline 13 & 1 mei 2018 & 191129 & 383442 & zooldiep & $\begin{array}{l}\text { (bramen) } \\
\text { rand van }\end{array}$ & $\begin{array}{l}\text { pijpestrootje } \\
\text { riet/piipestro }\end{array}$ & berken & gesloten & 1 & nu nat & 0.05 & 75 & 30 & 0 & 2 & links van het pad \\
\hline 14 & 1 mei 2018 & 192695 & 383290 & enkeldiep & plas & otje & $\begin{array}{l}\text { wilgenbos } \\
\text { wilgenbroek }\end{array}$ & halfopen & 2 & nu nat & 0.25 & ? & 4 & 0 & 2 & rechts van het pad \\
\hline 15 & 1 mei 2018 & 192613 & 383310 & laarsdiep & plas & & & gesloten & 0 & $\begin{array}{l}\text { permanent nat } \\
\text { permanent }\end{array}$ & 1 & ? & ? & 0 & 1 & \\
\hline 16 & 1 mei 2018 & 192761 & 383221 & droog & pijpestrootje & 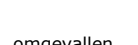 & berken & gesloten & -1 & droog & 0 & ? & $?$ & 0 & 1 & \\
\hline 17 & 1 mei 2018 & 192825 & 383195 & laarsdiep & $\begin{array}{l}\text { pijpestrootje } \\
\text { nat }\end{array}$ & $\begin{array}{l}\text { omgevallen } \\
\text { boom }\end{array}$ & berken & gesloten & 5 & nu nat & 1 & 5 & 5 & 0 & 1 & 5 omgevallen bomen \\
\hline 18 & 1 mei 2018 & 192846 & 383173 & laarsdiep & pijpestrootje & flap & $\begin{array}{l}\text { berken } \\
\text { wilgenbroek }\end{array}$ & gesloten & 0 & nu nat & 0.05 & 400 & 20 & 0 & 2 & \\
\hline 19 & 1 mei 2018 & 192956 & 383214 & laarsdiep & $\begin{array}{l}\text { geen/water } \\
\text { ruigte }\end{array}$ & & bos & gesloten & 0 & permanent nat & 1 & 100 & 50 & 0 & 2 & \\
\hline 20 & 1 mei 2018 & 193007 & 383490 & enkeldiep & (bramen) & & berken & gesloten & 0 & nu nat & 0.25 & ? & ? & 0 & 1 & locatie adultenval 18 \\
\hline 21 & 7 mei 2018 & 189774 & 383365 & droog & pijpestrootje & & berken & gesloten & 0 & nu droog & 0 & 200 & 50 & enkele & 2 & \\
\hline 22 & 7 mei 2018 & 189749 & 383262 & laarsdiep & 8 & $\begin{array}{l}\text { flap+eenden } \\
\text { kroos }\end{array}$ & & open & 0 & $\begin{array}{l}\text { permanent } \\
\text { droog }\end{array}$ & 1 & 400 & 10 & 0 & 4 & \\
\hline 23 & 7 mei 2018 & 189688 & 383210 & enkeldiep & $\begin{array}{l}\text { pijpestrootje } \\
\text { +varen }\end{array}$ & eendenkroos & berken & gesloten & 3 & nu nat & 0.25 & 400 & 40 & veel & 4 & strook naast kanaal tot $5 \mathrm{~m}$ drassig \\
\hline 24 & 7 mei 2018 & 189826 & 382992 & enkeldiep & pijpestrootje & & berken & halfopen & 1 & nu nat & 0.5 & ? & 40 & 0 & 3 & \\
\hline 25 & 7 mei 2018 & 189839 & 383056 & enkeldiep & pijpestrootje & moeras & berken & halfopen & 0 & nu nat & 0.5 & 50 & 50 & enkele & 2 & \\
\hline 26 & 7 mei 2018 & 189840 & 383280 & laarsdiep & pijpestrootje & veenmos & berken & halfopen & 0 & $\begin{array}{l}\text { permanent nat } \\
\text { nu }\end{array}$ & 0.5 & 40 & 100 & 0 & 3 & \\
\hline 27 & 7 mei 2018 & 189670 & 383258 & droog & pijpestrootje & & berken & halfopen & -1 & & 0 & 40 & 20 & 0 & 1 & \\
\hline 28 & 7 mei 2018 & 189672 & 383358 & droog & pijpestrootje & & berken/eik & gesloten & 0 & nu droog & 0 & 40 & 60 & 0 & 1 & \\
\hline
\end{tabular}




\begin{tabular}{|c|c|c|c|c|c|c|c|c|c|c|c|c|c|c|c|c|}
\hline $\mathrm{Nr}$ & Datum & $x$ & $\mathbf{Y}$ & $\begin{array}{l}\text { Water- } \\
\text { diepte }\end{array}$ & $\begin{array}{l}\text { VegType } \\
\text { Onder1 }\end{array}$ & $\begin{array}{l}\text { VegType } \\
\text { Onder2 }\end{array}$ & $\begin{array}{l}\text { VegType } \\
\text { Boven }\end{array}$ & $\begin{array}{l}\text { Bescha- } \\
\text { duwing }\end{array}$ & $\begin{array}{l}\text { Aantal } \\
\text { Dips }\end{array}$ & Permanentie & OppNat & Lengte & Breedte & $\begin{array}{l}\text { Obs- } \\
\text { Adult }\end{array}$ & Foto & Opmerking \\
\hline 29 & 7 mei 2018 & 189670 & 383390 & enkeldiep & pijpestrootje & eendenkroos & berken & halfopen & 0 & $\begin{array}{l}\text { nu } \\
\text { nat/permanent }\end{array}$ & 0.5 & 20 & 20 & 0 & 2 & \\
\hline 30 & 7 mei 2018 & 189342 & 383484 & droog & pijpestrootje & & berken & gesloten & -1 & droog & 0 & $?$ & 50 & enkele & 1 & \\
\hline 31 & 7 mei 2018 & 189025 & 383430 & droog & pijpestrootje & & berken & open & -1 & $\begin{array}{l}\text { permanent } \\
\text { droog }\end{array}$ & 0 & 75 & 50 & 0 & 2 & \\
\hline 32 & 7 mei 2018 & 189010 & 383324 & droog & pijpestrootje & & berken & gesloten & -1 & nu droog & 0 & 50 & 100 & veel & 1 & \\
\hline 33 & 7 mei 2018 & 189971 & 383277 & enkeldiep & pijpestrootje & & berken & open & 5 & nu nat & 0.25 & 50 & 100 & veel & 3 & \\
\hline 34 & 7 mei 2018 & 189946 & 383293 & laarsdiep & pijpestrootje & & berken & halfopen & 5 & nu nat & 0.5 & 50 & 40 & enkele & 3 & \\
\hline 35 & 7 mei 2018 & 189922 & 385233 & enkeldiep & pijpestrootje & & berken & halfopen & 5 & nu nat & 0.05 & 10 & 20 & enkele & 3 & \\
\hline 36 & 7 mei 2018 & 189856 & 383384 & zooldiep & pijpestrootje & veenmos & wilg & gesloten & 2 & nu nat & 0.25 & 20 & 50 & veel & 2 & \\
\hline 37 & 7 mei 2018 & 190605 & 383546 & laarsdiep & $\begin{array}{l}\text { pijpestrootje } \\
\text { ruigte }\end{array}$ & veenmos & berken & halfopen & 0 & $\begin{array}{l}\text { permanent nat } \\
\text { permanent }\end{array}$ & 0.75 & 200 & 40 & 0 & 4 & \\
\hline 38 & 7 mei 2018 & 190569 & 383566 & droog & (bramen) & & eik & gesloten & -1 & $\begin{array}{l}\text { droog } \\
\text { permanent }\end{array}$ & 0 & 200 & 20 & veel & 2 & \\
\hline 41 & 8 mei 2018 & 189302 & 383617 & droog & varens & & berk/eik & gesloten & -1 & droog & 0 & 150 & 50 & enkele & 2 & plek adultenval \\
\hline 42 & 8 mei 2018 & 189307 & 383531 & enkeldiep & pijpestrootje & varens & berk & halfopen & 4 & nu nat & 0.25 & 75 & 20 & veel & 4 & \\
\hline 43 & 8 mei 2018 & 189223 & 383486 & laarsdiep & pitrus & veenmos & & open & 4 & permanent nat & 1 & 50 & 50 & enkele & 2 & \\
\hline 44 & 8 mei 2018 & 189156 & 383556 & enkeldiep & pijpestrootje & pitrus & berk & halfopen & 4 & nu nat & 0.5 & 300 & 50 & enkele & 3 & \\
\hline 45 & 8 mei 2018 & 189132 & 383594 & droog & varens & bramen & & gesloten & -1 & $\begin{array}{l}\text { permanent } \\
\text { droog }\end{array}$ & 0 & 100 & 50 & veel & 2 & rechts van het pad \\
\hline 46 & 8 mei 2018 & 189085 & 383611 & droog & pijpestrootje & & berk & halfopen & 4 & nu droog & $<0.5$ & 50 & 50 & enkele & 3 & \\
\hline 47 & 8 mei 2018 & 188915 & 383568 & laarsdiep & pijpestrootje & veenmos & berk & halfopen & 3 & nu nat & 0.5 & 200 & 75 & 0 & 2 & \\
\hline 48 & 8 mei 2018 & 188975 & 383705 & droog & pitrus & nat grasland & & open & -1 & nu droog & 0 & 100 & 20 & 0 & 3 & \\
\hline 49 & 8 mei 2018 & 189348 & 383467 & drassig & pijpestrootje & & berk & halfopen & -1 & nu droog & 0 & 100 & 75 & veel & 2 & \\
\hline 50 & 8 mei 2018 & 189350 & 383454 & laarsdiep & veenmos & pijpestrootje & berk & halfopen & 0 & permanent nat & 1 & 100 & 40 & veel & 3 & tussen strook en locatie 49 \\
\hline 51 & 8 mei 2018 & 189304 & 383408 & laarsdiep & pijpestrootje & veenmos & berk (dood) & halfopen & 3 & permanent nat & 0.5 & 100 & 100 & 0 & 3 & \\
\hline 52 & 8 mei 2018 & 189435 & 383416 & droog & varens & & berk & gesloten & -1 & droog & 0 & 200 & 80 & 0 & 1 & \\
\hline 53 & 8 mei 2018 & 189417 & 383351 & enkeldiep & veenmos & $\begin{array}{l}\text { flap }+ \\
\text { pijpestrootje }\end{array}$ & berk & halfopen & 4 & permanent nat & 0.25 & $\begin{array}{l}\text { ?langspa } \\
\text { d }\end{array}$ & 10 & veel & 3 & rand van het wilgenbos \\
\hline 54 & 8 mei 2018 & 189192 & 383347 & zooldiep & pijpestrootje & veenmos & berk (dood) & halfopen & 4 & nu nat & 0.05 & 200 & 75 & 0 & 3 & rechts van de wal \\
\hline 55 & 8 mei 2018 & 189160 & 383374 & kniediep & pitrus & veenmos & & open & 0 & permanent nat & 1 & 200 & 50 & veel & 3 & $\begin{array}{l}\text { links van de val, op de wal adult: } \\
\text { heel veel }\end{array}$ \\
\hline 56 & 8 mei 2018 & 189095 & 383319 & laarsdiep & pijpestrootje & $\begin{array}{l}\text { pitrus }+ \\
\text { veenmos }\end{array}$ & $\begin{array}{l}\text { berk } \\
\text { (opslag) }\end{array}$ & halfopen & 1 & permanent nat & 1 & 400 & 75 & 0 & 3 & \\
\hline 57 & 8 mei 2018 & 189047 & 382941 & nu nat & heide & veenpluis & & open & 0 & nu nat & 0.05 & 400 & 80 & 0 & 6 & zonnedauw \\
\hline 58 & 8 mei 2018 & 189740 & 382420 & kniediep & pitrus & veenmos & & open & 0 & $\begin{array}{l}\text { permanent nat } \\
\text { permanent }\end{array}$ & 1 & 60 & 30 & 0 & 2 & kopkant van het water \\
\hline 59 & 8 mei 2018 & 189712 & 382459 & droog & varens & & berk & gesloten & -1 & droog & 0 & 200 & 50 & enkele & 1 & \\
\hline
\end{tabular}




\begin{tabular}{|c|c|c|c|c|c|c|c|c|c|c|c|c|c|c|c|c|}
\hline $\mathbf{N r}$ & Datum & $\mathbf{x}$ & $\mathbf{Y}$ & $\begin{array}{l}\text { Water- } \\
\text { diepte }\end{array}$ & $\begin{array}{l}\text { VegType } \\
\text { Onder1 }\end{array}$ & $\begin{array}{l}\text { VegType } \\
\text { Onder2 }\end{array}$ & $\begin{array}{l}\text { VegType } \\
\text { Boven }\end{array}$ & $\begin{array}{l}\text { Bescha- } \\
\text { duwing }\end{array}$ & $\begin{array}{l}\text { Aantal } \\
\text { Dips }\end{array}$ & Permanentie & OppNat & Lengte & Breedte & $\begin{array}{l}\text { Obs- } \\
\text { Adult }\end{array}$ & Foto & Opmerking \\
\hline 60 & 8 mei 2018 & 189697 & 382560 & droog & varens & & berk & gesloten & -1 & $\begin{array}{l}\text { permanent } \\
\text { droog }\end{array}$ & 0 & 200 & 100 & 0 & 1 & \\
\hline 61 & 8 mei 2018 & 189617 & 383266 & droog & varens & & berk & gesloten & -1 & $\begin{array}{l}\text { permanent } \\
\text { droog } \\
\text { nu } \\
\text { nat/permanent }\end{array}$ & 0 & 400 & 150 & 0 & 2 & \\
\hline 62 & 8 mei 2018 & 189532 & 382749 & enkeldiep & veenmos & pijpestrootje & berk & gesloten & 3 & ? & 0.5 & 200 & 80 & enkele & 2 & a. cinereus \\
\hline 63 & 8 mei 2018 & 189518 & 382820 & droog & droog gras & & & open & -1 & $\begin{array}{l}\text { permanent } \\
\text { droog }\end{array}$ & 0 & 400 & 200 & 0 & 2 & \\
\hline 64 & 8 mei 2018 & 189745 & 382915 & droog & pijpestrootje & & berk & $\begin{array}{l}\text { gesloten } \\
\text { halfopen } \\
\text { (wordt }\end{array}$ & -1 & $\begin{array}{l}\text { droog } \\
\text { drent }\end{array}$ & 0 & 200 & 40 & 0 & 2 & a. cinereus \\
\hline 65 & 9 mei 2018 & 191129 & 384553 & enkeldiep & plas/dras & & berk & $\begin{array}{l}\text { open) } \\
\text { open }\end{array}$ & 0 & $\begin{array}{l}\text { nu nat } \\
\text { permanent }\end{array}$ & 0.5 & 100 & 50 & enkele & 3 & a. cinereus -adult, vlies algen \\
\hline 66 & 9 mei 2018 & 191125 & 384496 & droog & varens & & berk & halfopen & -1 & $\begin{array}{l}\text { droog } \\
\text { permanent }\end{array}$ & 0 & 100 & 40 & enkele & 1 & rand naast akker \\
\hline 67 & 9 mei 2018 & 191217 & 384476 & droog & & & gekapt bos & open & -1 & $\begin{array}{l}\text { Dermanent } \\
\text { droog }\end{array}$ & 0 & 100 & 80 & enkele & 2 & \\
\hline 68 & 9 mei 2018 & 191212 & 384360 & droog & varens & & berk & halfopen & -1 & $\begin{array}{l}\text { permanent } \\
\text { droog }\end{array}$ & 0 & 200 & 50 & 0 & 2 & \\
\hline 69 & 9 mei 2018 & 191230 & 384225 & laarsdiep & pijpestrootje & flap & berk & gesloten & -1 & $\begin{array}{l}\text { permanent?/nu } \\
\text { nat }\end{array}$ & 0.5 & 200 & 20 & enkele & 2 & a. cinereus, laarsdiep \\
\hline 70 & 9 mei 2018 & 191252 & 384167 & droog & varens & & & open & -1 & $\begin{array}{l}\text { permanent } \\
\text { droog }\end{array}$ & 0 & 150 & 50 & 0 & 1 & \\
\hline 71 & 9 mei 2018 & 191215 & 384147 & enkel-laars & pijpestrootje & flap & berk & gesloten & 0 & $\begin{array}{l}\text { nu nat } \\
\text { nu }\end{array}$ & 0.5 & 200 & 20 & veel & 2 & a. cinereus \\
\hline 72 & 9 mei 2018 & 191228 & 384043 & enkel & plas/dras & $\begin{array}{l}\text { pijpestrootje } \\
\text { +flap }\end{array}$ & berk & gesloten & 0 & $\begin{array}{l}\text { nat/permanent } \\
? \\
\text { permanent }\end{array}$ & 0.75 & 100 & 20 & enkele & 3 & dwars op 71 , a. cinereus \\
\hline 73 & 9 mei 2018 & 191217 & 384008 & droog & varens & & & open & -1 & $\begin{array}{l}\text { droog } \\
\text { nu }\end{array}$ & 0 & 50 & 75 & enkele & 2 & dwars op 72 \\
\hline 74 & 9 mei 2018 & 191308 & 383964 & laarsdiep & veenmos & $\begin{array}{l}\text { rest varen }+ \\
\text { plas/dras }\end{array}$ & berk & open & 0 & $\begin{array}{l}\text { nat/permanent } \\
?\end{array}$ & 0.75 & 200 & 40 & veel & 4 & dwars op 73 , a. cinereus, algen \\
\hline 75 & 9 mei 2018 & 191584 & 383891 & kniediep & plas & & & open & 0 & permanent nat & 1 & 400 & 50 & 0 & 4 & \\
\hline 76 & 9 mei 2018 & 191534 & 384162 & laarsdiep & plas & pijpestrootje & berk (dood) & open & 0 & permanent nat & 1 & 200 & 50 & 0 & 5 & \\
\hline 77 & 9 mei 2018 & 191462 & 384176 & droog/hoog & varens & & berken & open & -1 & $\begin{array}{l}\text { droog } \\
\text { drith }\end{array}$ & 0 & 200 & 50 & 0 & 1 & \\
\hline 78 & 9 mei 2018 & 191415 & 384203 & laars-knie & pijpestrootje & flap & berk (dood) & halfopen & 0 & permanent nat & 1 & 400 & 50 & enkele & 2 & \\
\hline 79 & 9 mei 2018 & 191373 & 384207 & droog & varens & & & open & -1 & $\begin{array}{l}\text { permanent } \\
\text { droog } \\
\text { permanent/nu }\end{array}$ & 0 & 400 & 80 & 0 & 1 & \\
\hline 80 & 9 mei 2018 & 191341 & 384266 & laarsdiep & pijpestrootje & veenmos & berk & halfopen & 0 & nat? & 0.75 & 200 & 40 & veel & 1 & a. cinereus \\
\hline 81 & 9 mei 2018 & 190950 & 383829 & laarsdiep & plas & & $\begin{array}{l}\text { wilgenbroek } \\
\text { bos }\end{array}$ & gesloten & 0 & $\begin{array}{l}\text { permanent nat } \\
\text { permanent }\end{array}$ & 1 & $?$ & ? & $\begin{array}{l}\text { heel } \\
\text { veel }\end{array}$ & 2 & $\begin{array}{l}\text { a. cinereus (volgende week adulten } \\
\text { vangen) }\end{array}$ \\
\hline 82 & 9 mei 2018 & 190779 & 383928 & droog & varens & bramen & elzen/eiken & gesloten & -1 & $\begin{array}{l}\text { droog } \\
\text { drith }\end{array}$ & 0 & 200 & 50 & 0 & 2 & \\
\hline 83 & 14 mei 2018 & 190184 & 382033 & enkeldiep & nat grasland & pitrus & & open & 0 & nu nat & 0.25 & 300 & 100 & knut & 4 & \\
\hline 84 & 14 mei 2018 & 190262 & 382075 & enkeldiep & pijpestrootje & pitrus & berk & halfopen & 0 & nu nat & 0.25 & 100 & 10 & enkele & 3 & \\
\hline 85 & 14 mei 2018 & 190318 & 382163 & drassig & pijpestrootje & & berk & gesloten & -1 & nu droog & 0 & 200 & 20 & veel & 2 & \\
\hline 86 & 14 mei 2018 & 190429 & 382276 & droog & $\begin{array}{l}\text { oversteek } \\
\text { over }\end{array}$ & & & & 0 & & & & & veel & 2 & \\
\hline 87 & 14 mei 2018 & 190406 & 382308 & droog & pijpestrootje & & berk & halfopen & -1 & nu droog & 0 & 200 & 100 & veel & 1 & \\
\hline
\end{tabular}




\begin{tabular}{|c|c|c|c|c|c|c|c|c|c|c|c|c|c|c|c|}
\hline $\mathrm{Nr}$ & Datum & $\mathbf{x}$ & $\mathbf{Y}$ & $\begin{array}{l}\text { Water- } \\
\text { diepte }\end{array}$ & $\begin{array}{l}\text { VegType } \\
\text { Onder1 }\end{array}$ & $\begin{array}{l}\text { VegType } \\
\text { Onder2 }\end{array}$ & $\begin{array}{l}\text { VegType } \\
\text { Boven }\end{array}$ & $\begin{array}{l}\text { Bescha- } \\
\text { duwing }\end{array}$ & $\begin{array}{l}\text { Aantal } \\
\text { Dips }\end{array}$ & Permanentie & OppNat & Lengte & Breedte & $\begin{array}{l}\text { Obs- } \\
\text { Adult }\end{array}$ & Opmerking \\
\hline 88 & 14 mei 2018 & 190671 & 382381 & zooldiep & pijpestrootje & & berk & open & 3 & nu nat & 0.25 & 400 & 200 & enkele & 3 \\
\hline 89 & 14 mei 2018 & 190919 & 382742 & droog & pijpestrootje & & berk & gesloten & -1 & nu droog & 0 & 400 & 50 & veel & 2 \\
\hline 90 & 14 mei 2018 & 190754 & 382996 & zooldiep & pijpestrootje & veenmos & berk & gesloten & 0 & nu nat & 0.05 & 200 & 50 & veel & 3 \\
\hline 91 & 14 mei 2018 & 190647 & 382934 & drassig & pitrus & & wilg & halfopen & -1 & nu droog & 0 & 50 & 50 & veel & 2 \\
\hline 92 & 14 mei 2018 & 190773 & 383228 & enkeldiep & pijpestrootje & veenmos & berk & halfopen & 4 & nu nat & 0.5 & 50 & 50 & veel & 5 \\
\hline 93 & 14 mei 2018 & 190611 & 383138 & droog & & & $\begin{array}{l}\text { berk/ijsterb } \\
\text { es }\end{array}$ & gesloten & -1 & nu droog & 0 & 50 & 100 & veel & 1 \\
\hline 94 & 14 mei 2018 & 190515 & 383118 & droog & pitrus & ruig grasland & & open & -1 & nu droog & 0 & 100 & 100 & & 2 \\
\hline 95 & 14 mei 2018 & 190280 & 383149 & laarsdiep & pijpestrootje & & berk & halfopen & 1 & nu nat & 0.25 & 400 & 100 & enkele & 2 \\
\hline 96 & 14 mei 2018 & 190337 & 383059 & droog & & & eik/berk & gesloten & -1 & nu droog & 0 & 200 & 50 & enkele & 1 \\
\hline 97 & 14 mei 2018 & 190324 & 382972 & laarsdiep & veenmos & $\begin{array}{l}\text { pitrus } \\
\text { pijpstrootje }\end{array}$ & $\begin{array}{l}\text { berk/wilg } \\
\text { wilgenbroek }\end{array}$ & gesloten & 1 & nu nat & 0.75 & 200 & 50 & enkele & 5 \\
\hline 98 & 14 mei 2018 & 190174 & 382802 & kniepdiep & & & $\begin{array}{l}\text { bos } \\
\text { wilgenbroek }\end{array}$ & halfopen & 0 & permanent nat & 1 & 200 & 50 & enkele & 2 \\
\hline 99 & 14 mei 2018 & 190019 & 382925 & kniediep & pijpestrootje & & $\begin{array}{l}\text { bos } \\
\text { wilgenbroek }\end{array}$ & half open & 0 & permanent nat & 1 & 100 & 200 & enkele & 2 \\
\hline 100 & 14 mei 2018 & 190037 & 382620 & laarsdiep & & & $\begin{array}{l}\text { Wilgenbroek } \\
\text { bos } \\
\text { wilgenbroek }\end{array}$ & gesloten & 0 & permanent nat & 1 & & & enkele & 3 \\
\hline 101 & 14 mei 2018 & 190103 & 382528 & & & & $\begin{array}{l}\text { bos } \\
\text { wilgenbroek }\end{array}$ & gesloten & & permanent nat & 1 & & & & \\
\hline 102 & 14 mei 2018 & 190154 & 382482 & & & & & gesloten & & permanent nat & 1 & & & veel & 2 \\
\hline 103 & 14 mei 2018 & 188631 & 383592 & enkeldiep & veenmos & pijpestrootje & berk & halfopen & 0 & nu nat & 0.25 & 100 & 50 & veel & 3 \\
\hline 104 & 14 mei 2018 & 188537 & 383305 & enkeldiep & pijpestrootje & veenmos & berk & halfopen & 5 & nu nat & 0.25 & 100 & 50 & veel & 2 \\
\hline
\end{tabular}


Bijlage 4: Aantallen steekmuggen per soort en per locatie verzameld in 2015, 2016, 2017 en 2018.

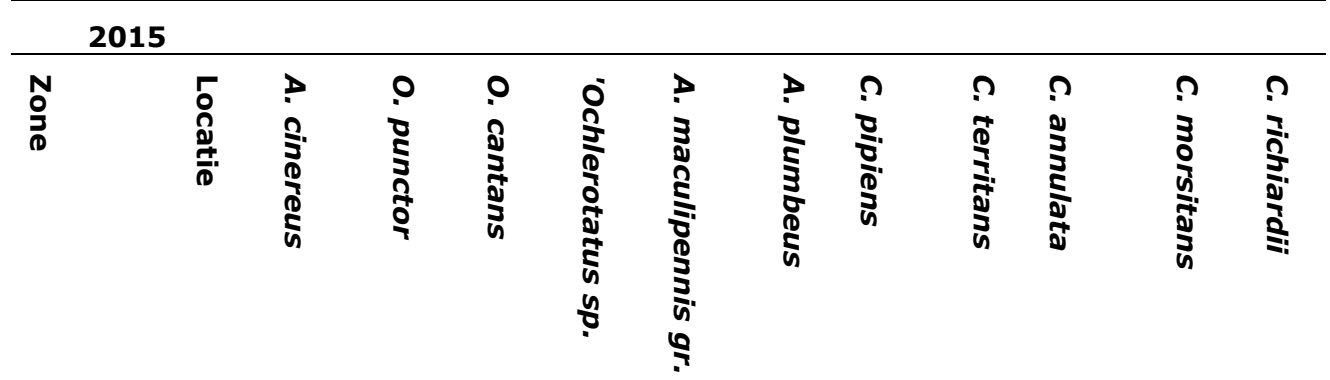

\begin{tabular}{lrrrrrrrrrrrr}
\hline Oost & 1 & 370 & 8 & 32 & 0 & 9 & 0 & 32 & 0 & 4 & 13 & 38 \\
Oost & 2 & 275 & 7 & 24 & 0 & 0 & 1 & 13 & 0 & 0 & 0 & 32 \\
Oost & 3 & 562 & 62 & 71 & 0 & 0 & 3 & 48 & 0 & 4 & 0 & 92 \\
Oost & 18 & 229 & 0 & 8 & 0 & 3 & 10 & 11 & 0 & 1 & 1 & 12 \\
Zuid & 4 & 733 & 60 & 111 & 0 & 0 & 28 & 3 & 0 & 0 & 1 & 40 \\
Zuid & 5 & 323 & 22 & 8 & 0 & 1 & 3 & 26 & 0 & 3 & 4 & 12 \\
Zuid & 7 & 829 & 33 & 25 & 0 & 38 & 11 & 5 & 0 & 2 & 0 & 39 \\
Zuid & 8 & 85 & 4 & 1 & 0 & 5 & 0 & 27 & 0 & 5 & 15 & 13 \\
West & 10 & 538 & 20 & 27 & 0 & 37 & 0 & 16 & 0 & 4 & 27 & 11 \\
West & 11 & 481 & 32 & 35 & 0 & 3 & 23 & 16 & 0 & 1 & 9 & 37 \\
West & 12 & 273 & 10 & 13 & 0 & 1 & 4 & 14 & 0 & 0 & 1 & 18 \\
West & 13 & 65 & 8 & 5 & 0 & 1 & 7 & 6 & 0 & 0 & 0 & 22 \\
Dorp oost & 6 & 134 & 6 & 7 & 0 & 1 & 1 & 66 & 0 & 2 & 20 & 38 \\
Dorp oost & 9 & 91 & 3 & 6 & 0 & 5 & 1 & 63 & 0 & 2 & 3 & 67 \\
Dorp & 14 & 18 & 16 & 9 & 0 & 2 & 1 & 15 & 0 & 0 & 0 & 41 \\
Dorp & 15 & 11 & 1 & 0 & 0 & 2 & 0 & 13 & 0 & 0 & 0 & 4 \\
Dorp & 16 & 51 & 1 & 5 & 0 & 1 & 6 & 40 & 0 & 0 & 1 & 26 \\
Dorp & 17 & 14 & 0 & 1 & 0 & 2 & 1 & 5 & 0 & 2 & 1 & 20 \\
\hline & & & & & & & & & & &
\end{tabular}

\begin{tabular}{|c|c|c|c|c|c|c|c|c|c|c|c|c|}
\hline \multicolumn{13}{|c|}{2016} \\
\hline 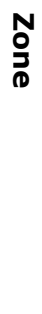 & 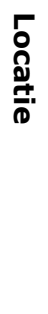 & 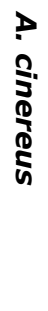 & 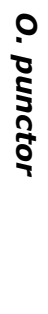 & 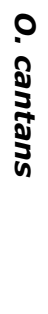 & 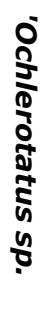 & 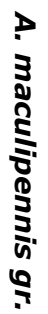 & 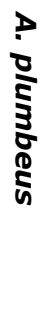 & 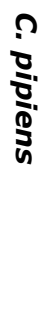 & 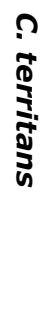 & 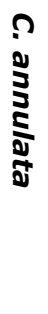 & 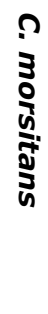 & 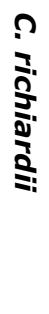 \\
\hline
\end{tabular}

\begin{tabular}{lrrrrrrrrrrrr}
\hline Oost & 1 & 119 & 46 & 29 & 0 & 6 & 0 & 595 & 16 & 3 & 88 & 17 \\
Oost & 2 & 93 & 18 & 2 & 0 & 0 & 1 & 1077 & 4 & 1 & 68 & 6 \\
Oost & 3 & 132 & 202 & 108 & 0 & 1 & 29 & 1412 & 0 & 6 & 20 & 30 \\
Oost & 18 & 71 & 59 & 33 & 0 & 0 & 0 & 1601 & 1 & 8 & 19 & 8 \\
Zuid & 4 & 172 & 33 & 21 & 0 & 4 & 6 & 141 & 1 & 4 & 32 & 2 \\
Zuid & 5 & 55 & 29 & 3 & 0 & 0 & 1 & 1226 & 0 & 2 & 17 & 3 \\
Zuid & 7 & 219 & 51 & 35 & 0 & 3 & 6 & 319 & 1 & 4 & 51 & 10 \\
Zuid & 8 & 101 & 39 & 34 & 0 & 11 & 0 & 970 & 0 & 10 & 11 & 16 \\
West & 10 & 306 & 31 & 7 & 0 & 5 & 4 & 267 & 5 & 2 & 13 & 22 \\
West & 11 & 207 & 60 & 53 & 0 & 13 & 25 & 2458 & 0 & 17 & 0 & 23
\end{tabular}




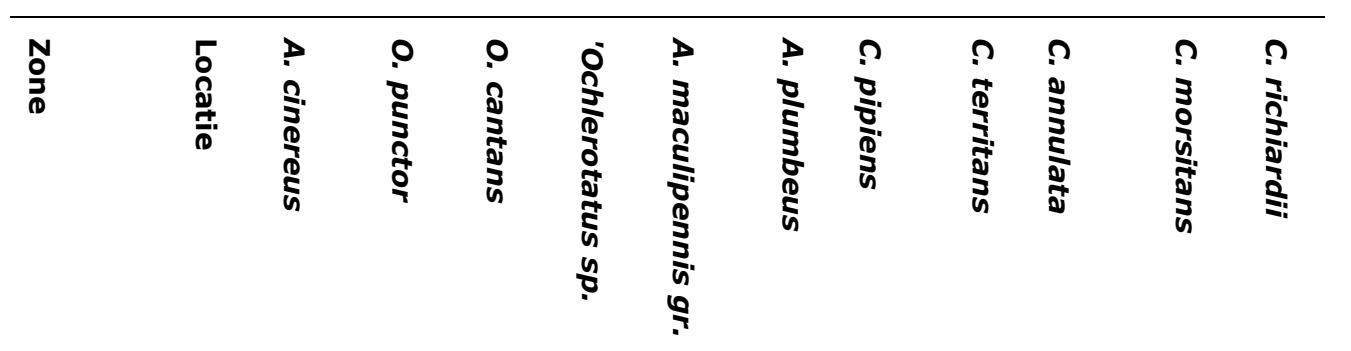

\begin{tabular}{lrrrrrrrrrrrr}
\hline West & 12 & 99 & 47 & 2 & 1 & 8 & 23 & 1201 & 0 & 4 & 0 & 1 \\
West & 13 & 138 & 17 & 8 & 0 & 1 & 1 & 930 & 4 & 2 & 0 & 8 \\
Dorp oost & 6 & 74 & 47 & 6 & 0 & 0 & 0 & 4512 & 0 & 7 & 27 & 6 \\
Dorp oost & 9 & 39 & 75 & 10 & 0 & 5 & 0 & 1639 & 20 & 1 & 37 & 31 \\
Dorp & 14 & 18 & 41 & 15 & 0 & 12 & 9 & 1228 & 20 & 13 & 13 & 9 \\
Dorp & 15 & 14 & 19 & 5 & 0 & 5 & 0 & 819 & 0 & 0 & 1 & 1 \\
Dorp & 16 & 24 & 95 & 2 & 0 & 1 & 4 & 1935 & 0 & 21 & 17 & 12 \\
Dorp & 17 & 20 & 0 & 1 & 0 & 14 & 3 & 1253 & 1 & 1 & 3 & 6 \\
\hline
\end{tabular}

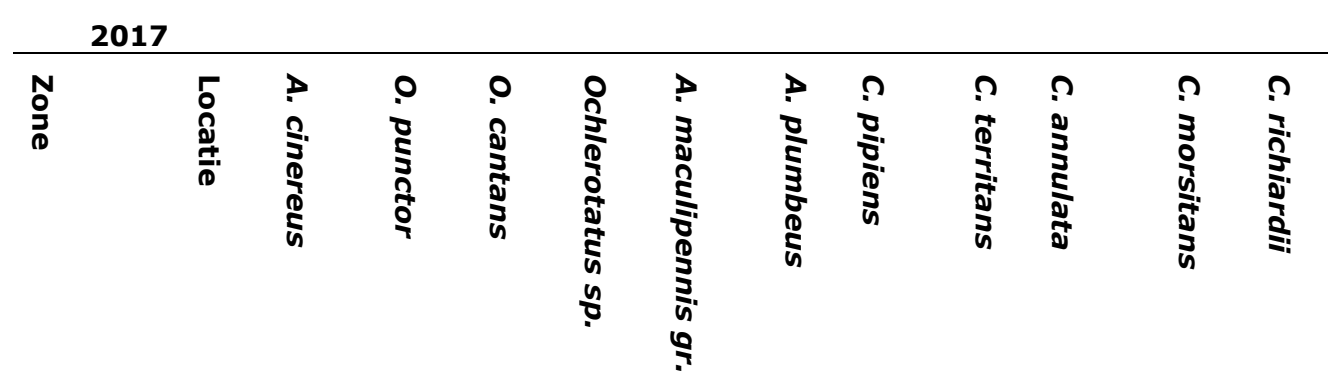

\begin{tabular}{lrrrrrrrrrrrr}
\hline Oost & 1 & 223 & 58 & 47 & 0 & 2 & 8 & 15 & 0 & 0 & 0 & 57 \\
Oost & 2 & 74 & 7 & 6 & 1 & 2 & 2 & 21 & 3 & 0 & 0 & 81 \\
Oost & 3 & 49 & 280 & 36 & 1 & 19 & 3 & 29 & 2 & 0 & 4 & 220 \\
Oost & 18 & 5 & 18 & 4 & 0 & 0 & 2 & 15 & 0 & 0 & 0 & 27 \\
Zuid & 4 & 466 & 59 & 33 & 0 & 2 & 11 & 4 & 0 & 0 & 6 & 81 \\
Zuid & 5 & 66 & 23 & 3 & 0 & 0 & 0 & 47 & 0 & 0 & 6 & 32 \\
Zuid & 7 & 206 & 168 & 45 & 0 & 1 & 4 & 12 & 0 & 4 & 12 & 24 \\
Zuid & 8 & 74 & 0 & 1 & 0 & 0 & 0 & 13 & 0 & 2 & 15 & 16 \\
West & 10 & 134 & 20 & 47 & 0 & 7 & 6 & 21 & 0 & 0 & 1 & 49 \\
West & 11 & 24 & 160 & 56 & 0 & 5 & 18 & 10 & 0 & 1 & 4 & 13 \\
West & 12 & 20 & 9 & 4 & 0 & 4 & 5 & 28 & 0 & 0 & 4 & 11 \\
West & 13 & 11 & 89 & 64 & 0 & 9 & 4 & 29 & 0 & 0 & 9 & 17 \\
Dorp oost & 6 & 47 & 28 & 10 & 0 & 17 & 5 & 57 & 0 & 7 & 0 & 28 \\
Dorp oost & 9 & 51 & 20 & 5 & 0 & 9 & 1 & 35 & 6 & 1 & 2 & 63 \\
Dorp & 14 & 8 & 41 & 19 & 0 & 2 & 12 & 23 & 0 & 0 & 3 & 46 \\
Dorp & 15 & 3 & 9 & 0 & 0 & 2 & 0 & 28 & 0 & 0 & 0 & 2 \\
Dorp & 16 & 9 & 26 & 3 & 0 & 2 & 3 & 46 & 0 & 1 & 0 & 20 \\
Dorp & 17 & 10 & 18 & 3 & 0 & 3 & 1 & 44 & 1 & 1 & 0 & 26
\end{tabular}




\begin{tabular}{|c|c|c|c|c|c|c|c|c|c|c|c|c|c|c|}
\hline 2018 & & & & & & & & & & & & & & \\
\hline N & 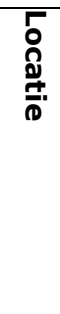 & 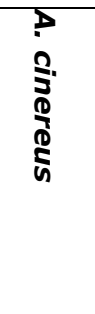 & 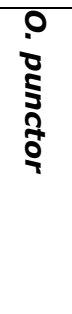 & $\begin{array}{l}0 \\
\dot{0} \\
\tilde{y} \\
\tilde{\tilde{y}} \\
\tilde{3}\end{array}$ & 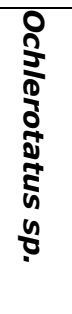 & 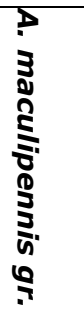 & 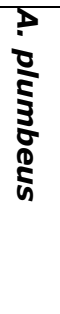 & 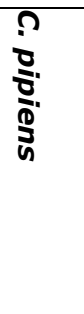 & 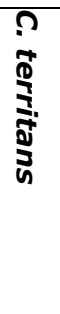 & 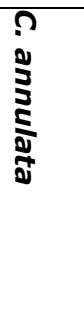 & 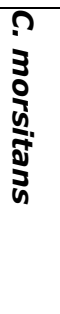 & 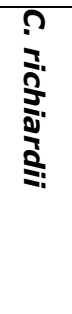 & 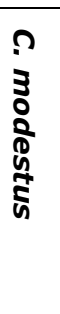 & 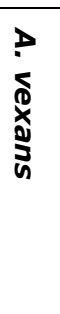 \\
\hline Oost & 1 & 2096 & 56 & & 8 & 5 & 31 & 36 & & & 2 & 133 & & \\
\hline Oost & 2 & 1194 & 8 & & 2 & 2 & 3 & 37 & & & 1 & 36 & 2 & \\
\hline Oost & 3 & 986 & 104 & 24 & 22 & 46 & & 69 & & & 2 & 87 & 3 & \\
\hline Oost & 18 & 243 & 23 & & 3 & 1 & 1 & 38 & & 1 & 2 & 11 & & \\
\hline Zuid & 4 & 1973 & 35 & & 10 & 8 & 1 & 3 & & & 2 & 37 & & \\
\hline Zuid & 5 & 1610 & 11 & & 4 & 5 & & 84 & 1 & & 10 & 35 & 1 & \\
\hline Zuid & 7 & 1009 & 21 & & 10 & 7 & & 12 & & 2 & 12 & 11 & 4 & \\
\hline Zuid & 8 & 828 & 4 & & 4 & 2 & & 12 & & & 5 & 8 & 1 & \\
\hline West & 10 & 3504 & 24 & & 105 & 10 & & 46 & & & 8 & 43 & 1 & \\
\hline West & 11 & 1545 & 132 & 4 & 10 & 23 & 1 & 55 & & 7 & & 29 & 3 & \\
\hline West & 12 & 293 & 5 & & 1 & 7 & 5 & 16 & & 3 & & 16 & 1 & \\
\hline West & 13 & 345 & & & & 2 & & 27 & & & & 6 & 2 & 1 \\
\hline $\begin{array}{l}\text { Dorp } \\
\text { oost } \\
\text { Dorp }\end{array}$ & 6 & 1112 & 839 & & 29 & 56 & 1 & 140 & & & 2 & 52 & 1 & \\
\hline oost & 9 & 441 & 113 & & 10 & 41 & 3 & 77 & & 9 & 3 & 85 & 3 & \\
\hline Dorp & 14 & 426 & 36 & & 7 & 3 & 11 & 91 & & & & 33 & 2 & 1 \\
\hline Dorp & 15 & 123 & 2 & & 1 & 1 & & 49 & & & & 2 & & \\
\hline Dorp & 16 & 148 & 28 & & 2 & 5 & 2 & 137 & & & & 24 & 1 & \\
\hline Dorp & 17 & 126 & 17 & & 5 & 8 & 13 & 66 & & 2 & & 26 & 1 & \\
\hline
\end{tabular}


Bijlage 5: Aantallen knutten per soort en per locatie verzameld in 2015, 2016, 2017 en 2018.

\begin{tabular}{|c|c|c|c|c|c|c|c|c|c|c|c|}
\hline \multicolumn{12}{|l|}{2015} \\
\hline $\begin{array}{l}\text { No } \\
\text { Oֵ } \\
\text { D }\end{array}$ & 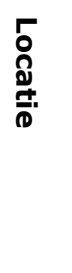 & 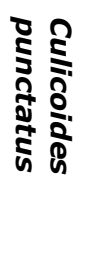 & 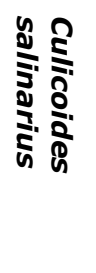 & 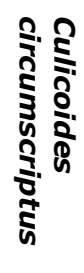 & 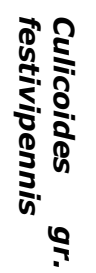 & 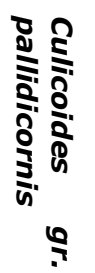 & 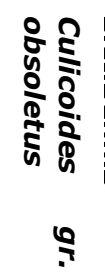 & 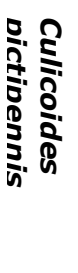 & 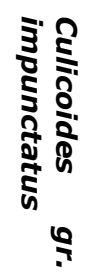 & 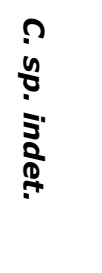 & 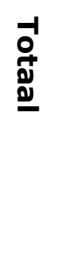 \\
\hline Oost & 1 & 96 & & 0 & 1 & 3 & 0 & 6 & 15 & & 121 \\
\hline Oost & 2 & 14 & & 0 & 0 & 7 & 1 & 4 & 31 & & 57 \\
\hline Oost & 3 & 83 & & 0 & 3 & 0 & 15 & 16 & 132 & & 249 \\
\hline Oost & 18 & 0 & & 0 & 0 & 0 & 3 & 0 & 279 & & 282 \\
\hline Zuid & 4 & 15 & & 0 & 1 & 1 & 98 & 1 & 16 & & 132 \\
\hline Zuid & 5 & 0 & & 0 & 1 & 0 & 0 & 1 & 4 & & 6 \\
\hline Zuid & 7 & 29 & & 0 & 6 & 6 & 7 & 0 & 26 & & 74 \\
\hline Zuid & 8 & 4 & & 0 & 0 & 0 & 0 & 1 & 6 & & 11 \\
\hline West & 10 & 2 & & 0 & 0 & 0 & 3 & 0 & 14 & & 19 \\
\hline West & 11 & 44 & & 0 & 0 & 1 & 2 & 1 & 43 & & 91 \\
\hline West & 12 & 10 & & 0 & 1 & 2 & 79 & 4 & 38 & & 134 \\
\hline West & 13 & 5 & & 0 & 8 & 4 & 9 & 0 & 73 & & 99 \\
\hline Dorp oost & 6 & 1 & & 2 & 0 & 0 & 2 & 0 & 271 & & 276 \\
\hline Dorp oost & 9 & 0 & & 0 & 0 & 5 & 4 & 3 & 65 & & 77 \\
\hline Dorp & 14 & 0 & & 0 & 0 & 0 & 0 & 0 & 9 & & 9 \\
\hline Dorp & 15 & 1 & & 0 & 0 & 0 & 1 & 0 & 13 & & 15 \\
\hline Dorp & 16 & 1 & & 0 & 0 & 0 & 0 & 0 & 0 & & 1 \\
\hline Dorp & 17 & 4 & & 0 & 0 & 0 & 4 & 0 & 4 & & 12 \\
\hline \multicolumn{12}{|l|}{2016} \\
\hline $\begin{array}{l}\text { No } \\
\text { ○̊ } \\
\text { D }\end{array}$ & 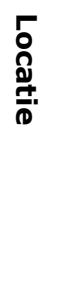 & 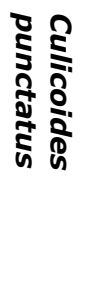 & 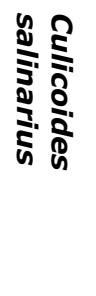 & 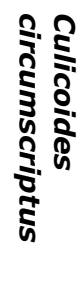 & 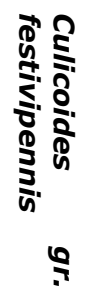 & 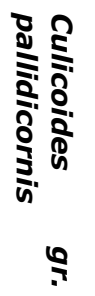 & 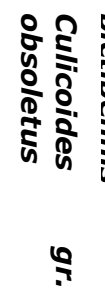 & 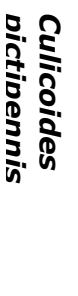 & 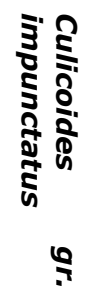 & $\begin{array}{l}n \\
n \\
0 \\
\vdots \\
5 \\
0 \\
0 \\
0\end{array}$ & $\begin{array}{l}\text {-1 } \\
\stackrel{+}{0} \\
\underline{0}\end{array}$ \\
\hline Oost & 1 & 34 & & 0 & 20 & 4 & 0 & 4 & 63 & 61 & 186 \\
\hline Oost & 2 & 54 & & 0 & 4 & 149 & 4 & 3 & 2 & 6 & 222 \\
\hline Oost & 3 & 16 & & 0 & 8 & 0 & 1 & 0 & 60 & 0 & 85 \\
\hline Oost & 18 & 79 & & 0 & 4 & 9 & 9 & 0 & 113 & 16 & 230 \\
\hline Zuid & 4 & 1 & & 0 & 0 & 0 & 1 & 0 & 7 & 0 & 9 \\
\hline Zuid & 5 & 3 & & 0 & 0 & 1 & 1 & 1 & 58 & 0 & 64 \\
\hline Zuid & 7 & 2 & & 0 & 0 & 1 & 0 & 0 & 63 & 0 & 66 \\
\hline Zuid & 8 & 1 & & 0 & 1 & 0 & 4 & 8 & 30 & 0 & 44 \\
\hline West & 10 & 0 & & 0 & 0 & 0 & 1 & 1 & 24 & 0 & 26 \\
\hline West & 11 & 2 & & 0 & 92 & 0 & 2 & 0 & 9 & 0 & 105 \\
\hline West & 12 & 4 & & 0 & 24 & 0 & 10 & 0 & 580 & 0 & 618 \\
\hline West & 13 & 1 & & 0 & 568 & 14 & 24 & 0 & 6 & 0 & 613 \\
\hline Dorp oost & 6 & 140 & & 0 & 0 & 0 & 16 & 0 & 92 & 0 & 248 \\
\hline
\end{tabular}




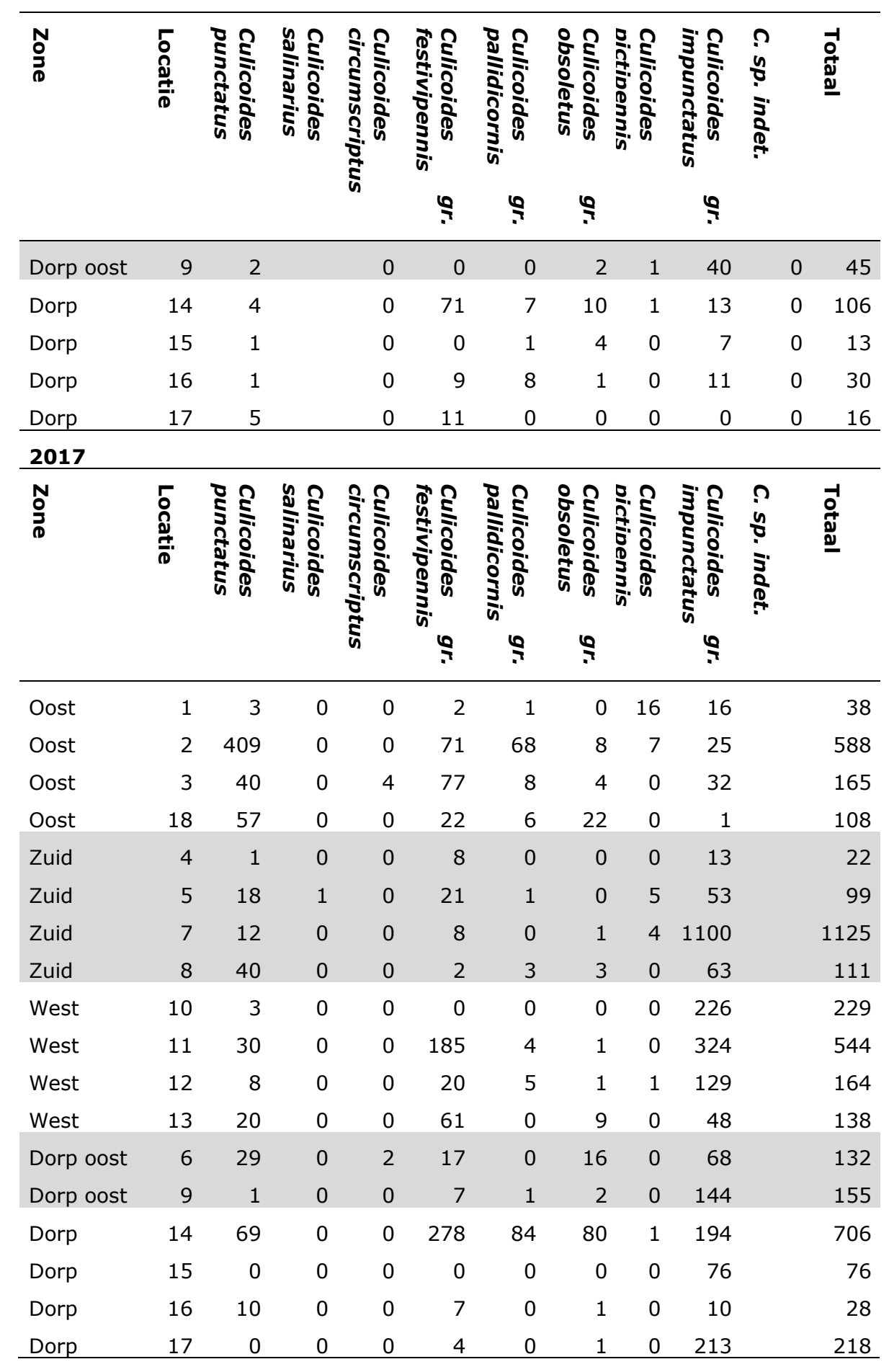




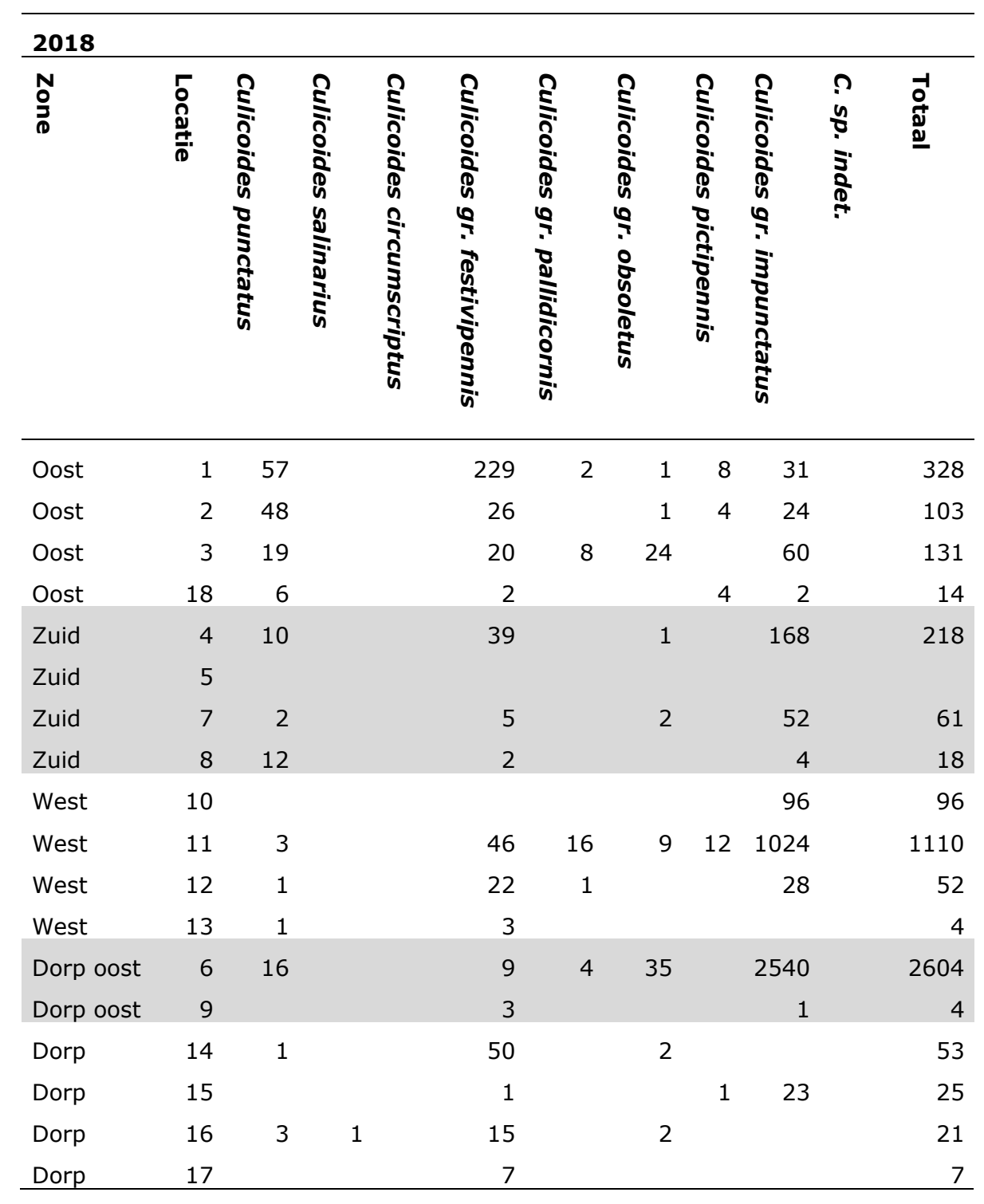




\section{Bijlage 6: Impressie van de meetlocaties}

Locatie 1, moerasgebied en overgangszone oost. Rand moerasbos.
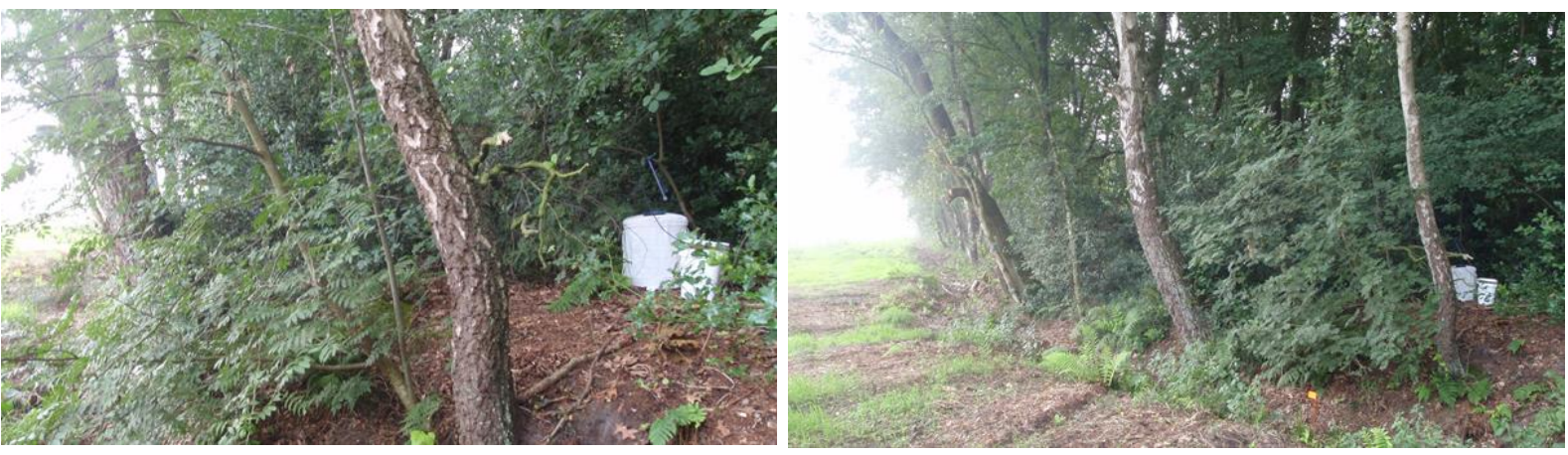

Locatie 2, moerasgebied en overgangszone oost. Rand moerasbos.
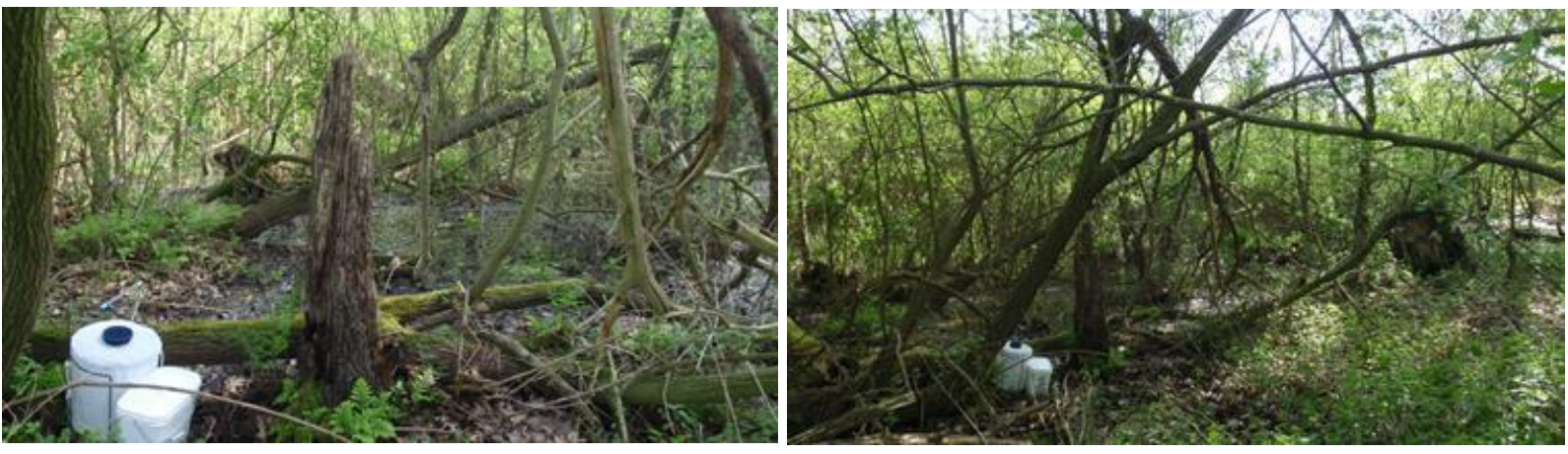

Locatie 3, moerasgebied en overgangszone oost. Tussen struiken in droog bos bij voetbalvelden.
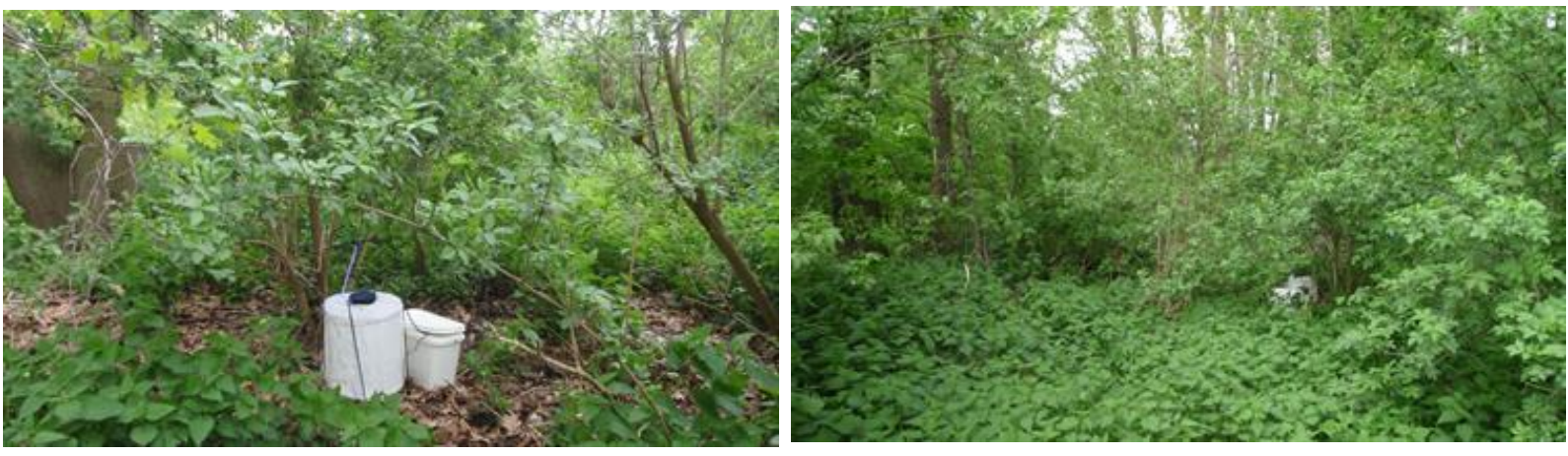

Locatie 4, moerasgebied en overgangszone zuid. Overgang van droog naar nat bos.
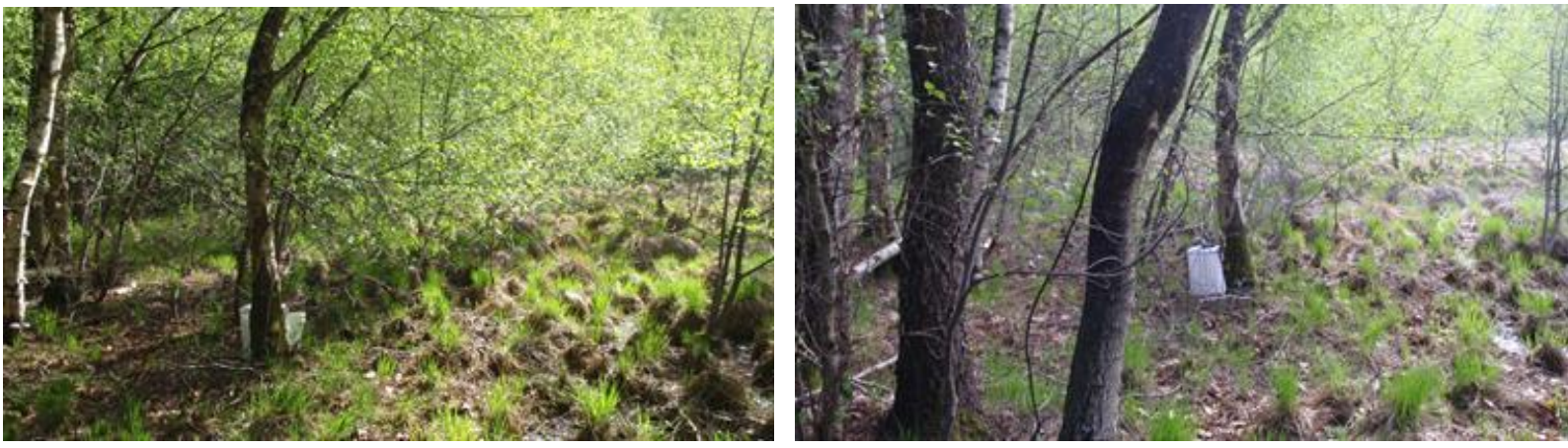
Locatie 5, moerasgebied en overgangszone zuid. Onder struiken aan rand van tuin thv Kanaalweg 12.
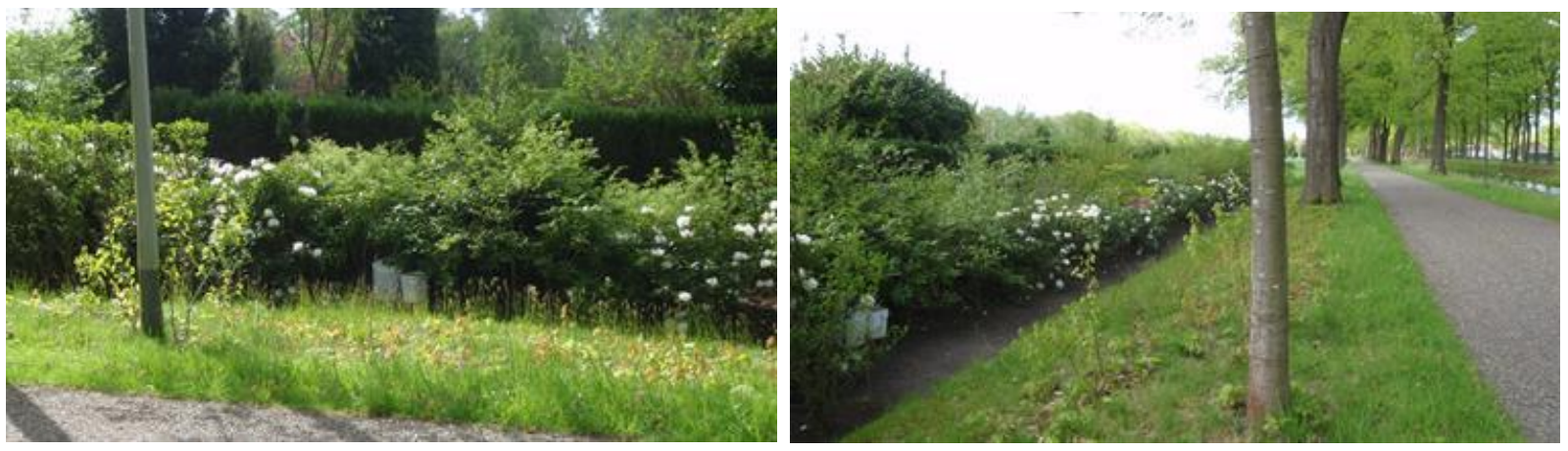

Locatie 6, dorp oost. Onder struiken aan rand van tuin en akkerland. Smelen.
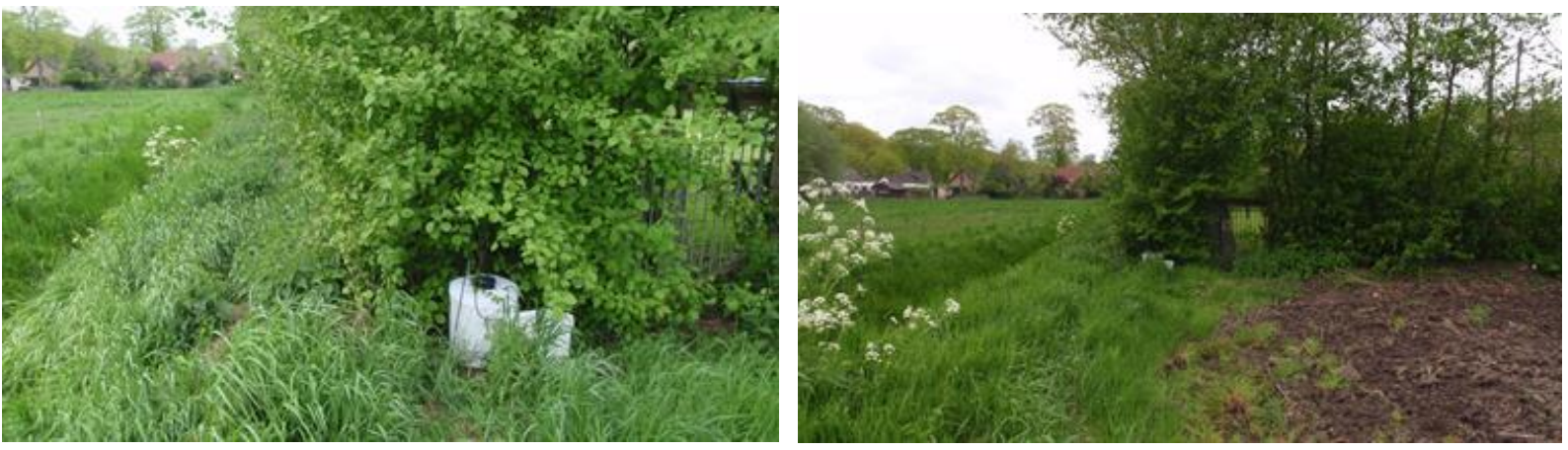

Locatie 7, moerasgebied en overgangszone zuid. Overgang van droog naar nat bos.
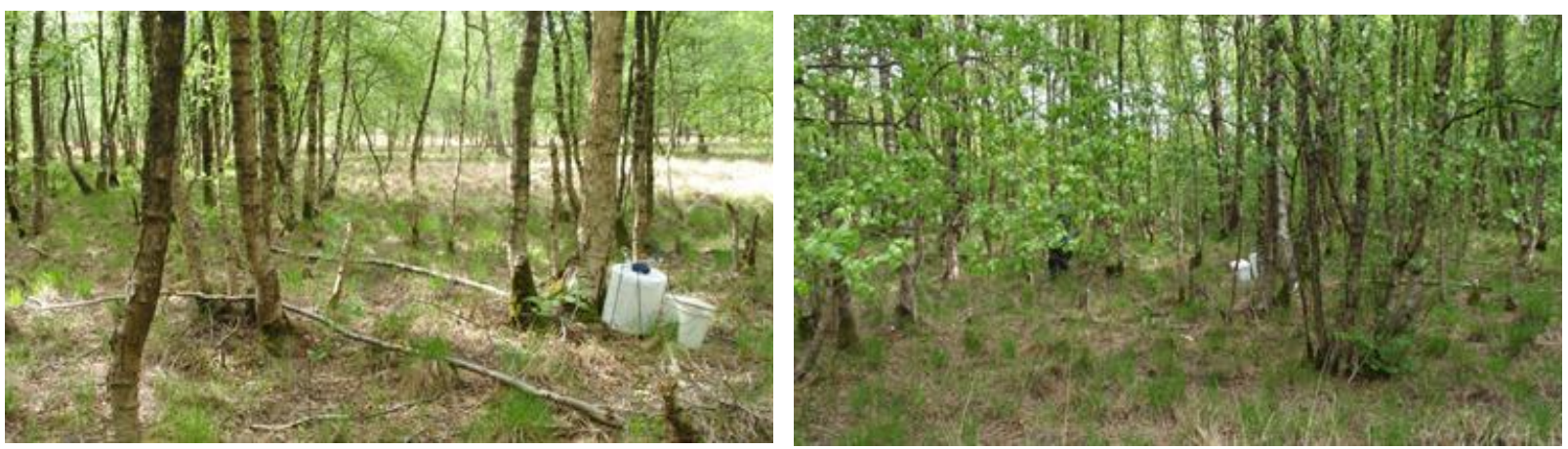

Locatie 8, moerasgebied en overgangszone zuid. In ruigte waar in 2015 en 2016 oude coniferenhaag stond.
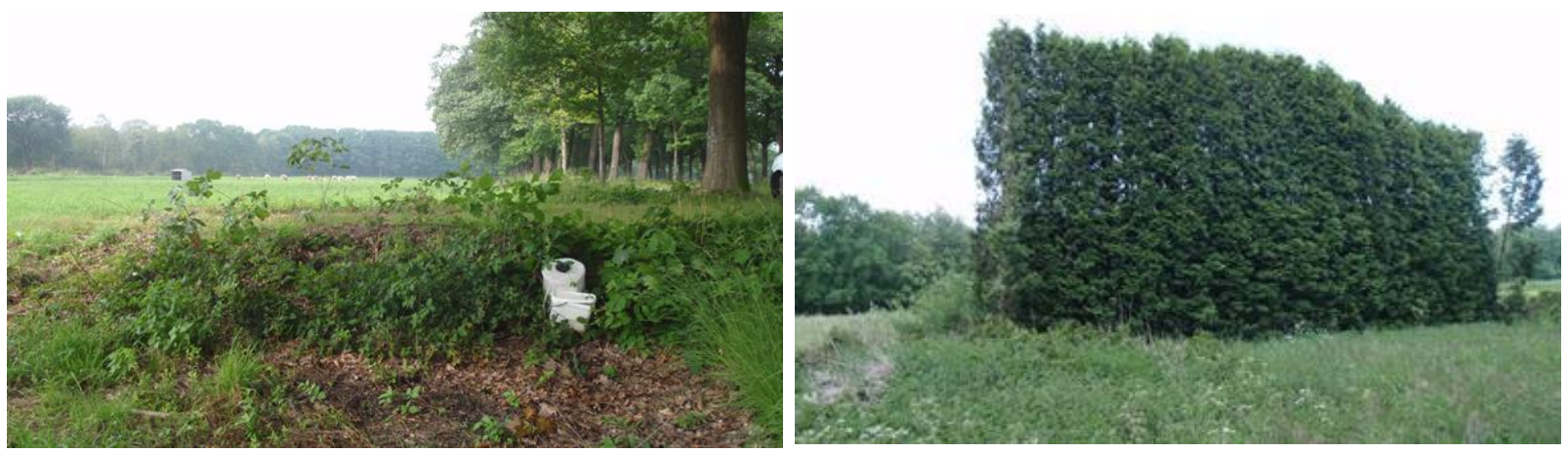
Locatie 9, dorp. Naast haag en onder kamperfoelie bij Apostelweg 16-18.
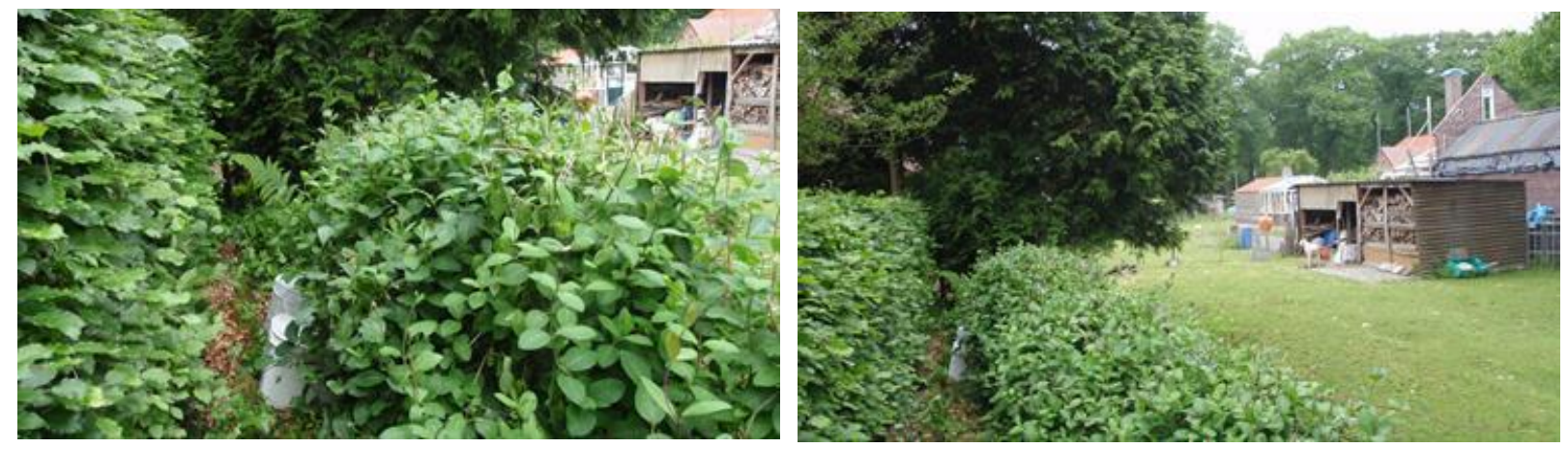

Locatie 10, moerasgebied en overgangszone west. Rand moerasbos.
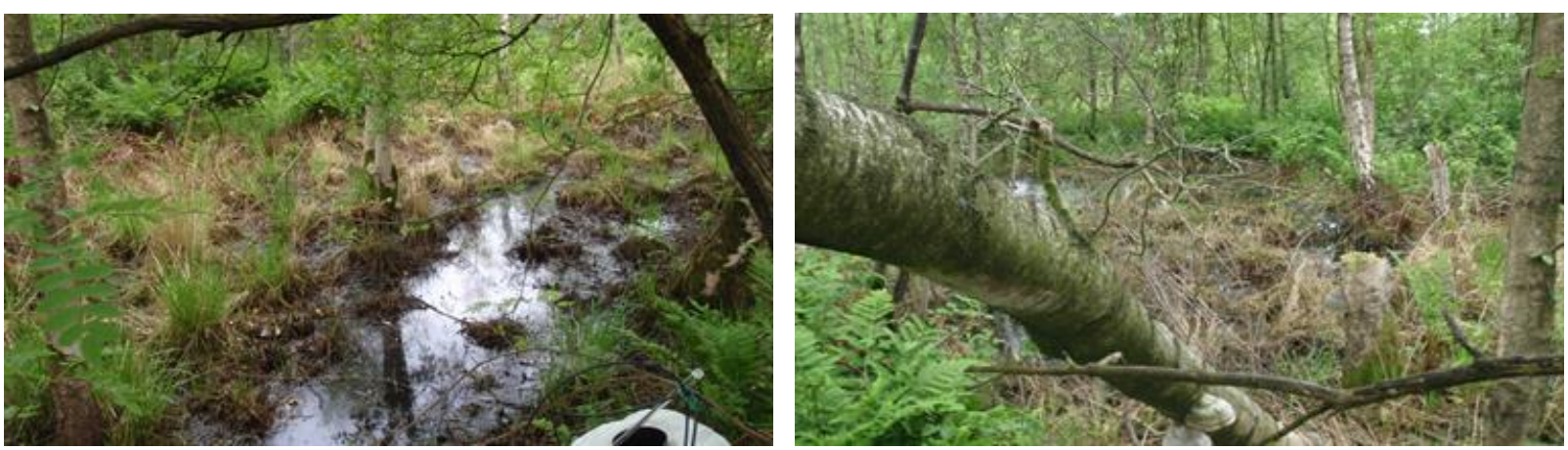

Locatie 11, moerasgebied en overgangszone west. Rand sloot, weiland en droog bos.
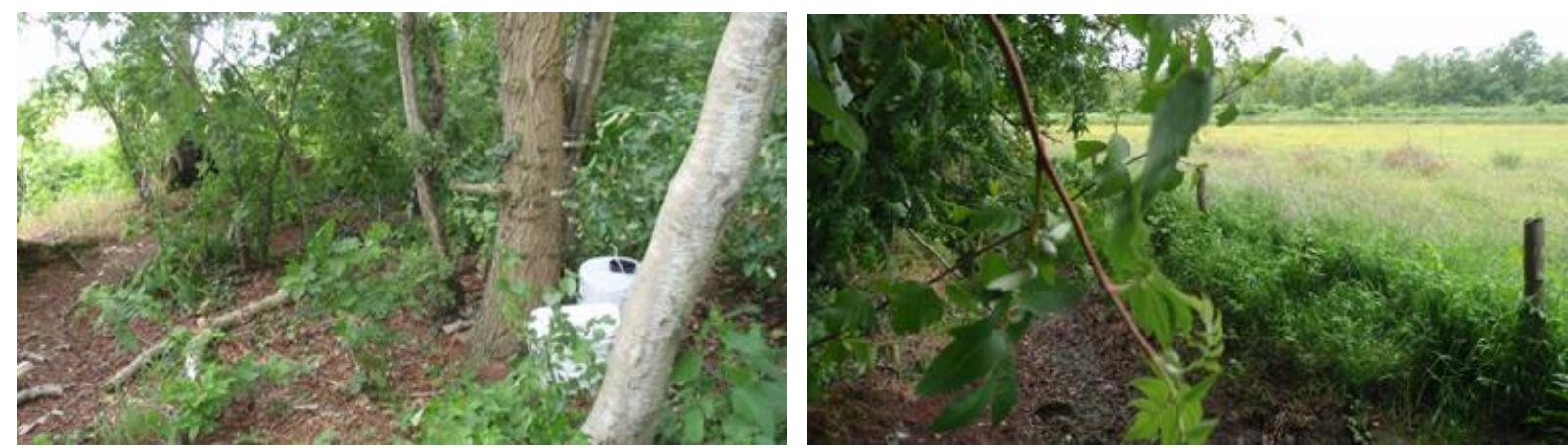

Locatie 12, moerasgebied en overgangszone west. Onder struiken in tuin bij Helenaveenseweg 62-64.
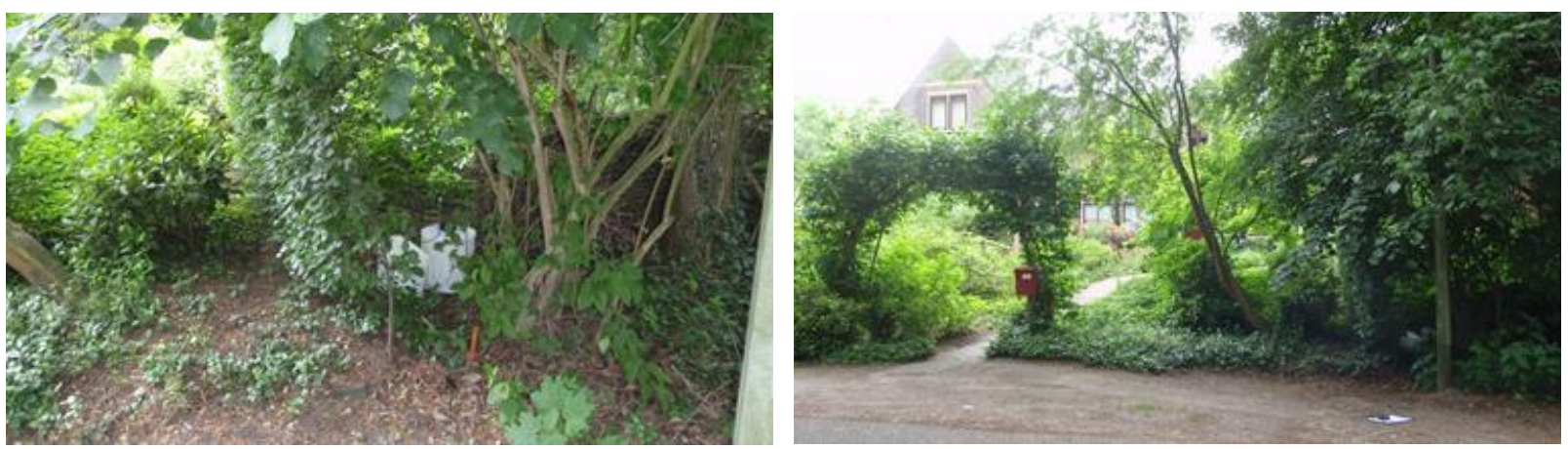
Locatie 13, moerasgebied en overgangszone west. Tussen struiken bij rand van tuin achter Paardestal.
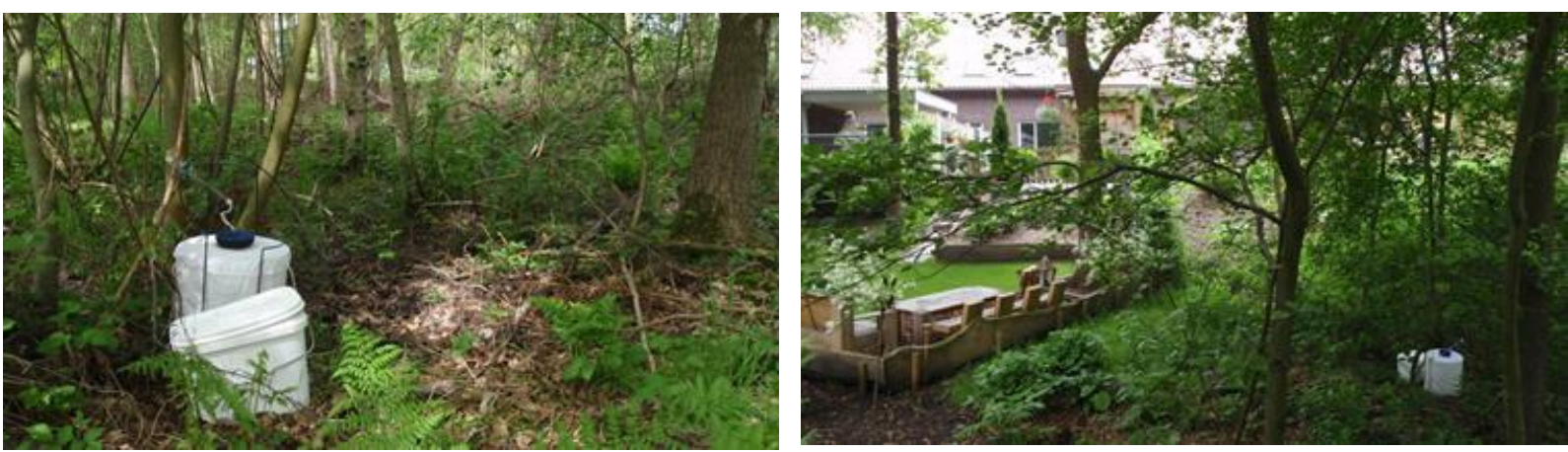

Locatie 14, dorp. Onder struiken. Apostelweg.
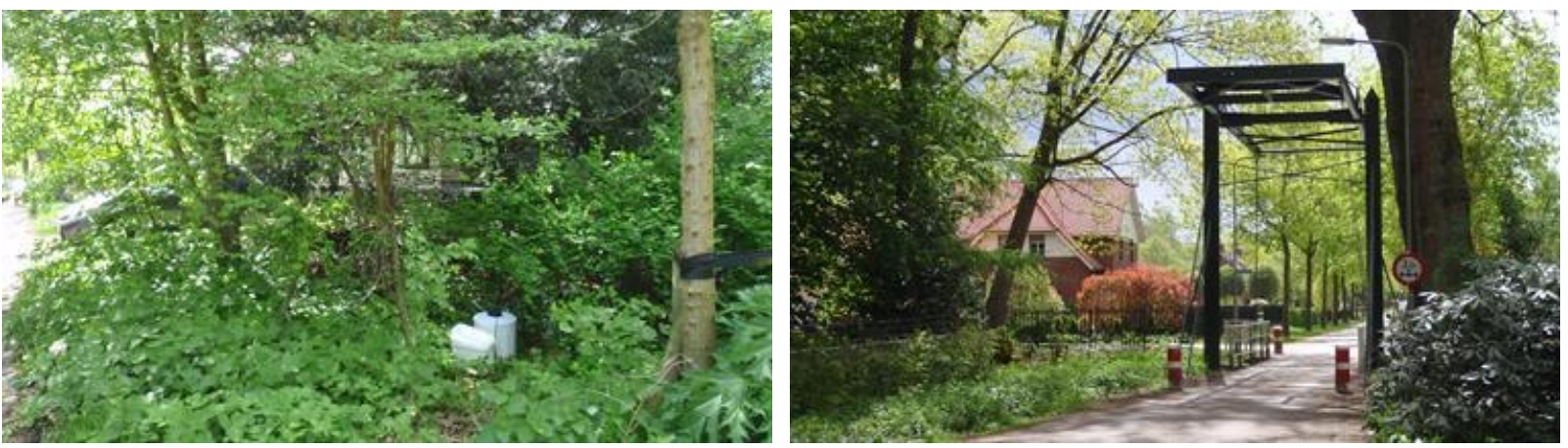

Locatie 15, dorp. Onder struiken in voortuin Pastoor Hendriksstraat 31.
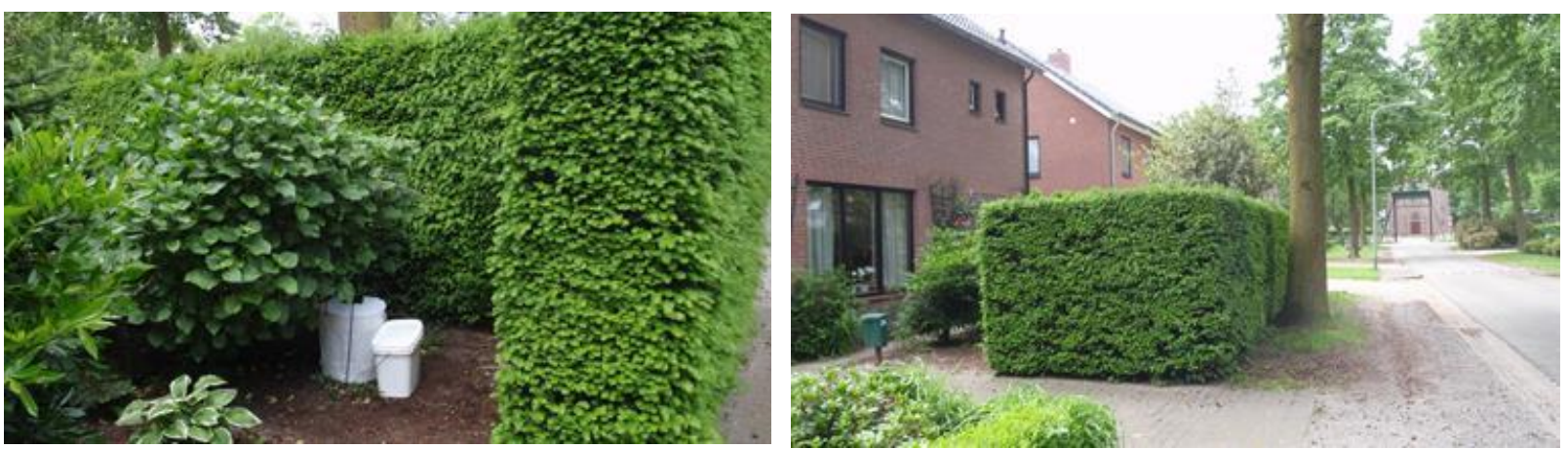

Locatie 16, dorp oost. Onder struiken in voortuin bij Lavendellaan 29.
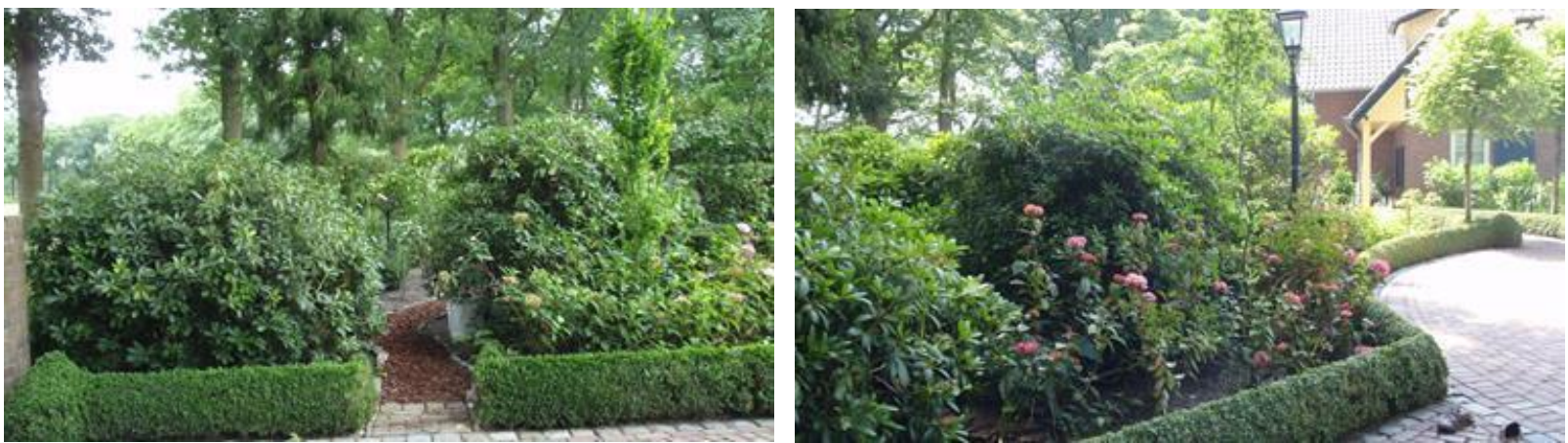
Locatie 17, dorp. Tussen struiken in voortuin Sphagnumweg 4.
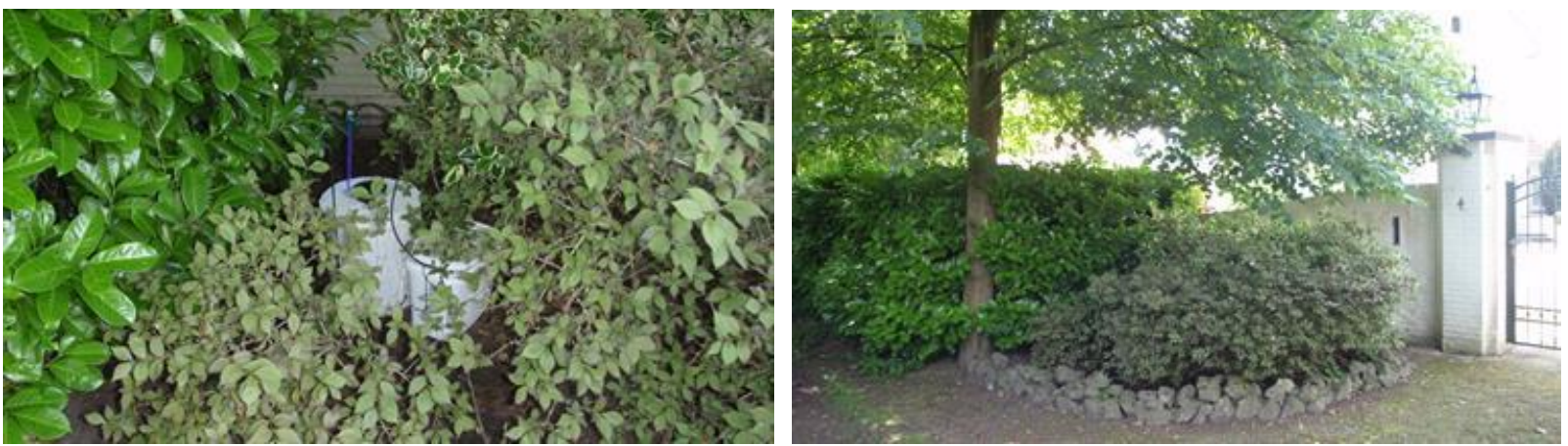

Locatie 18, moerasgebied en overgangszone oost. Rand moerasbos in buurt van Griendtsveenseweg 80.
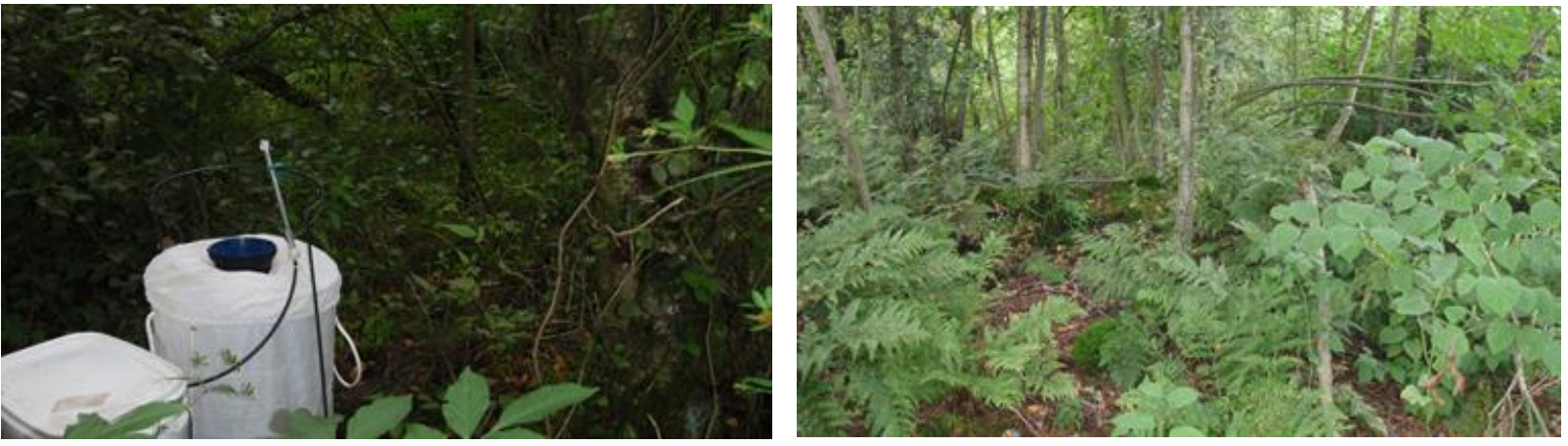


\section{Moerasgebied en overgangszone oost}

Moerasgebied oost in mei 2015.
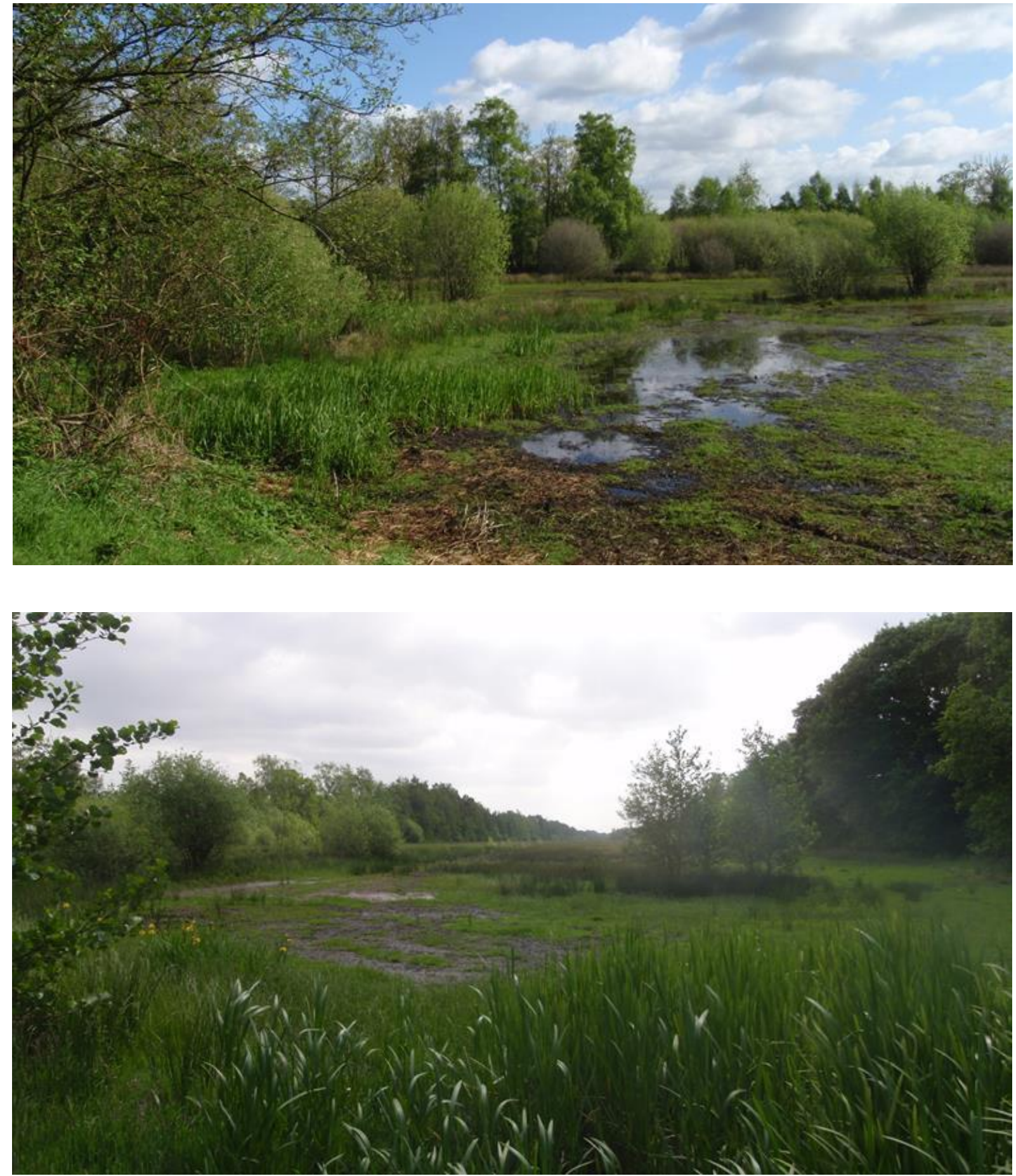

Moerasgebied oost in juni 2015. 
Moerasgebied en overgangszone zuid

Moerasgebied zuid in mei 2015.

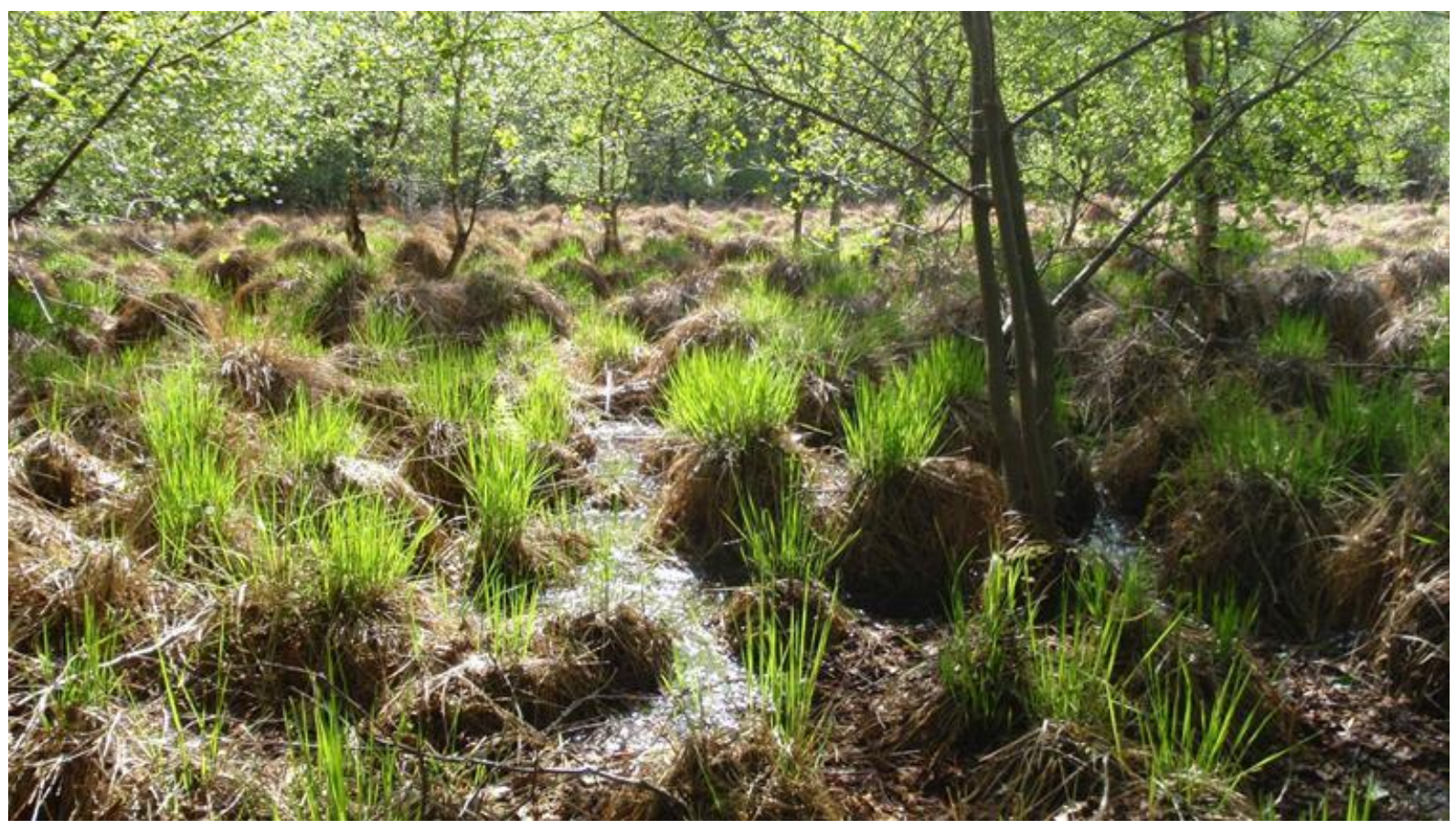

Moerasgebied zuid in september 2015.

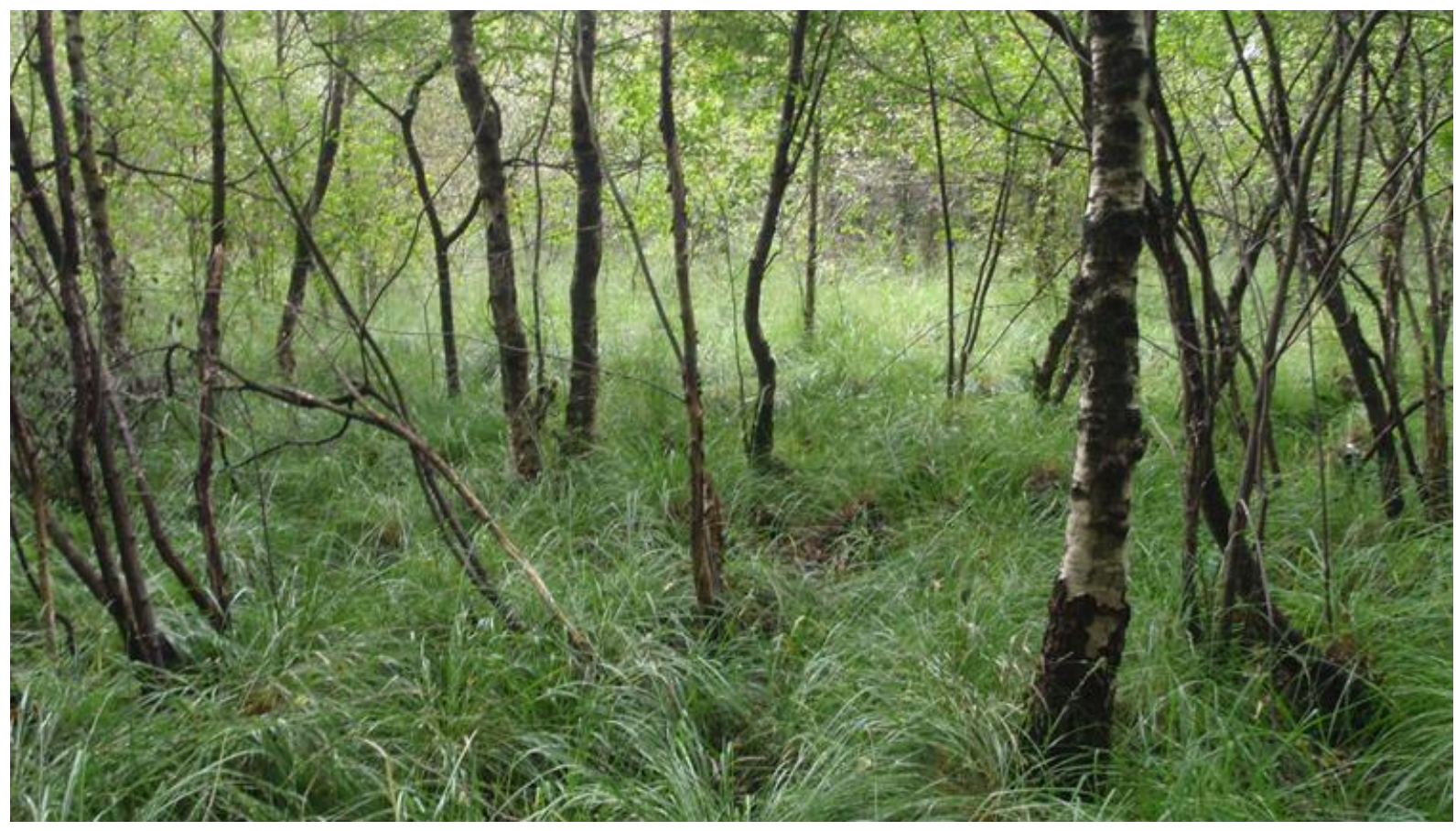


Overgangszone zuid in mei 2015.

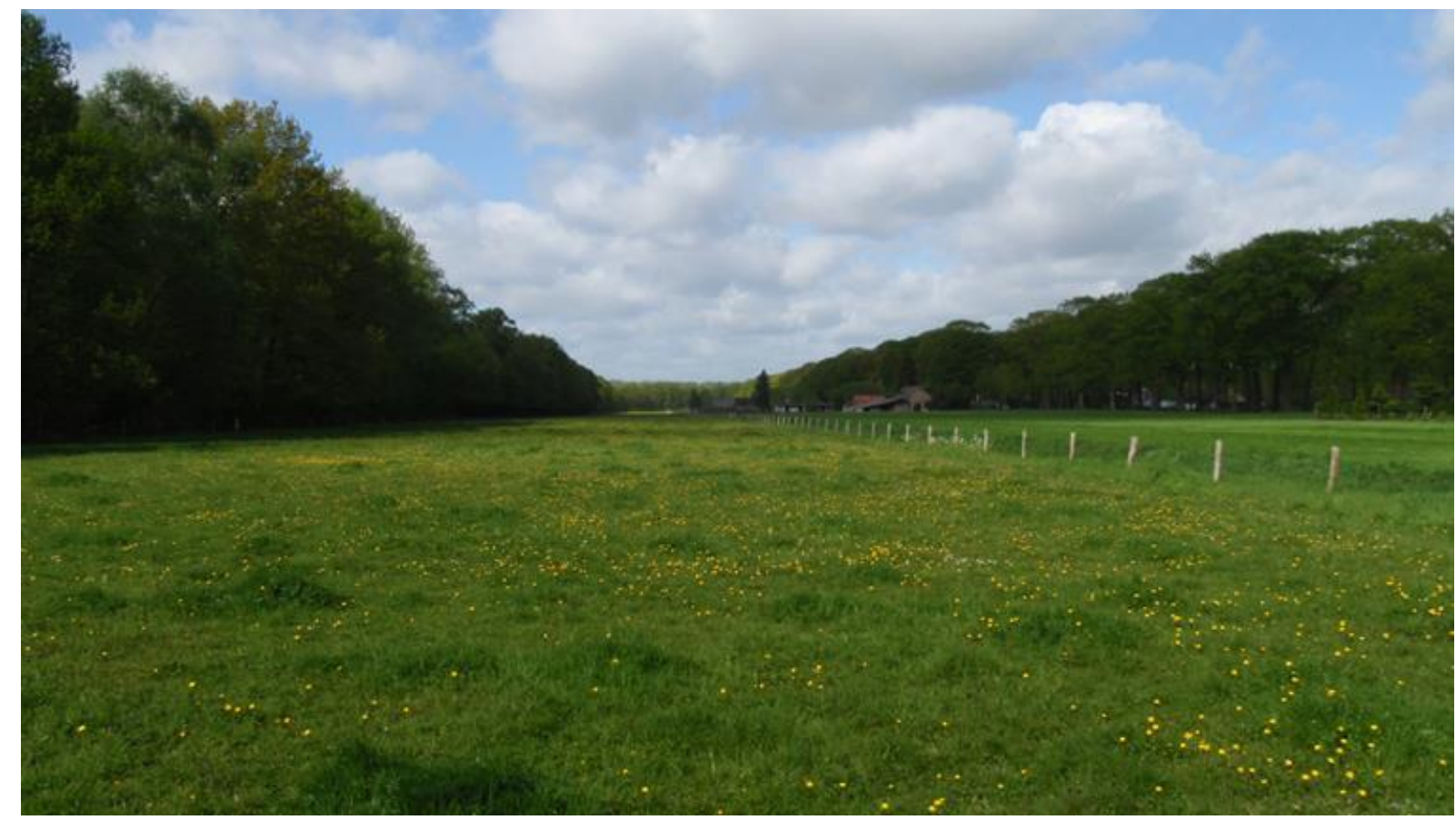

Overgangszone zuid in september 2015.

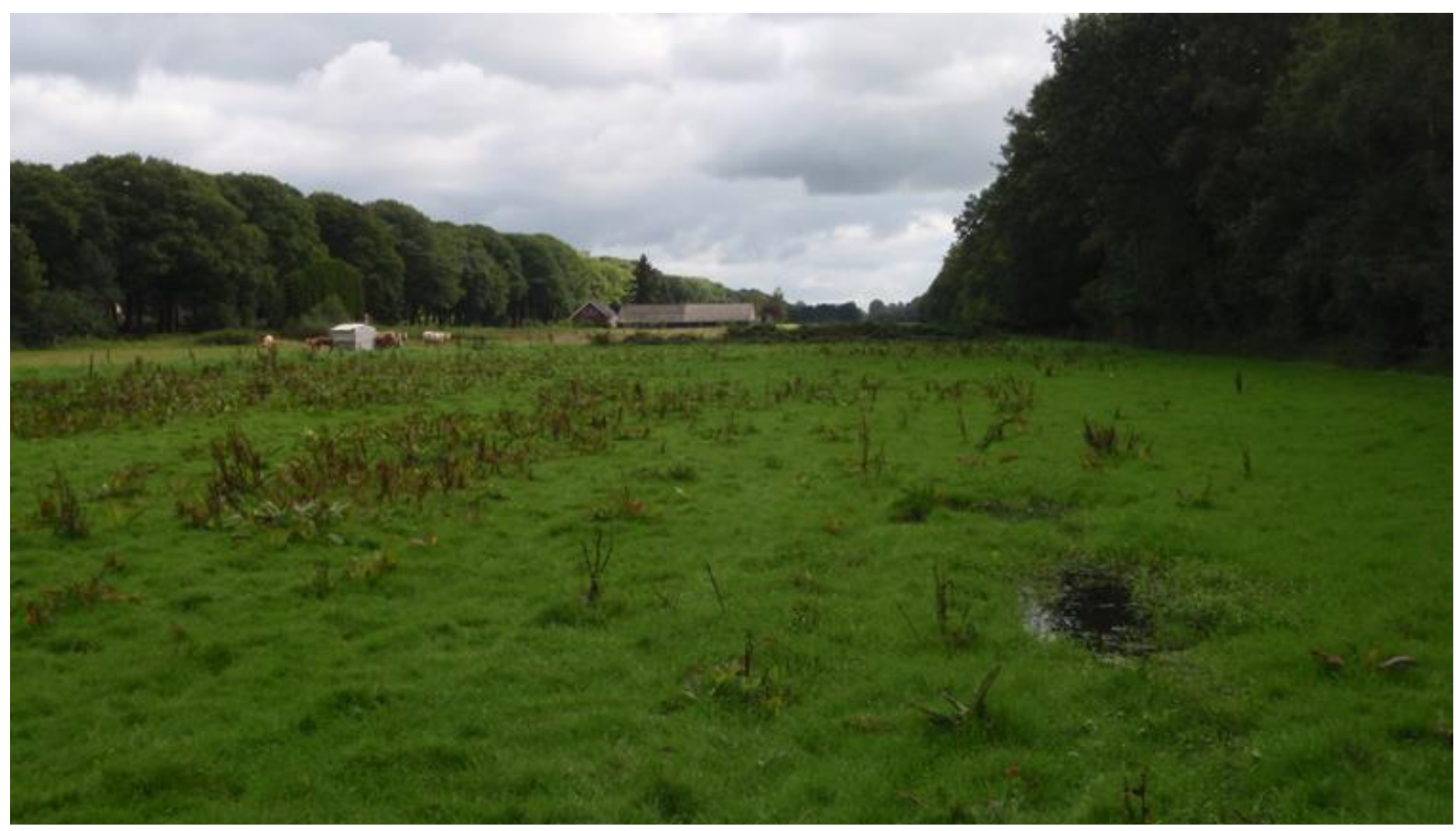


Moerasgebied en overgangszone west

Moerasgebied west in juni 2015.

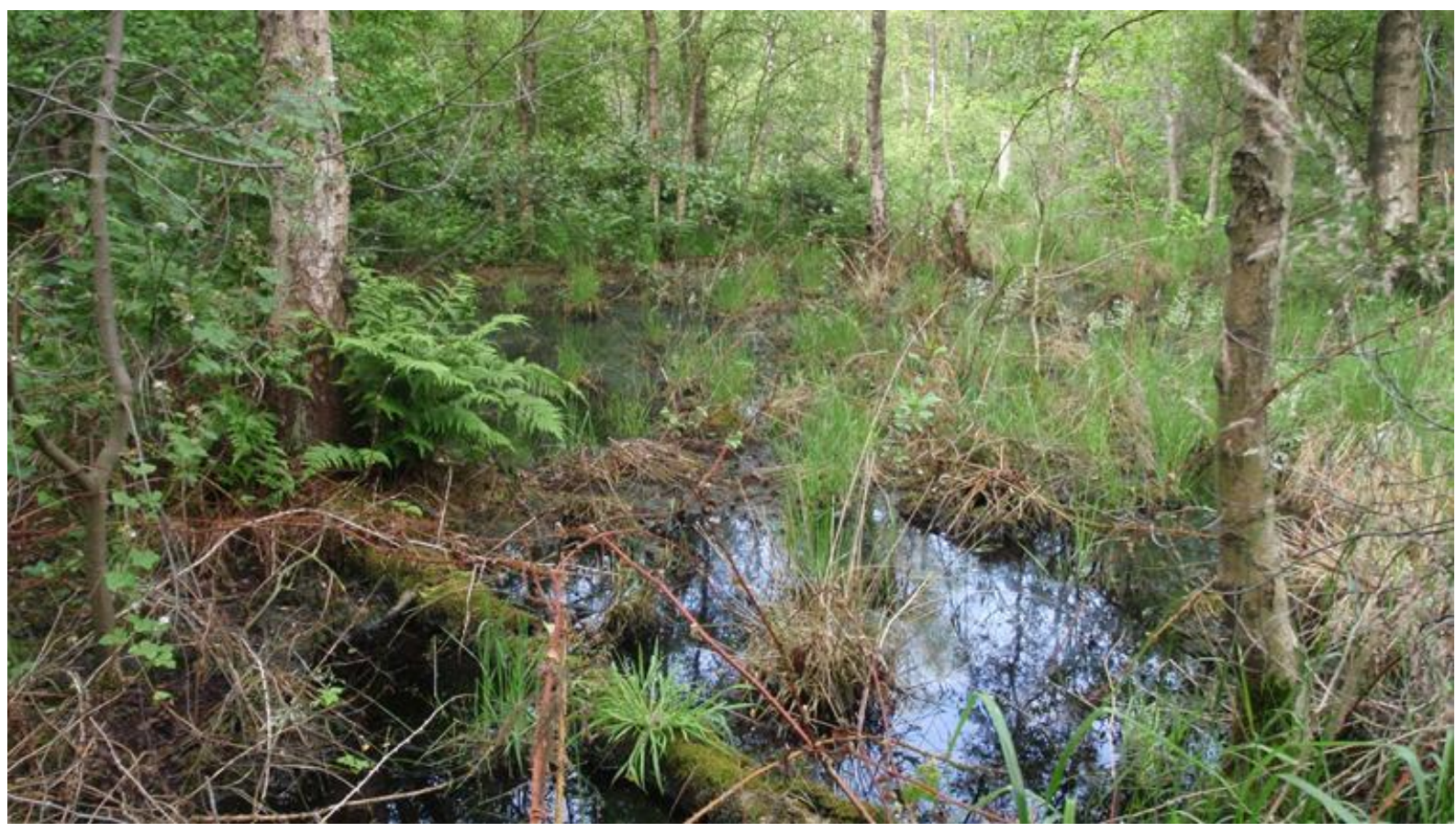

Kade west 2015.

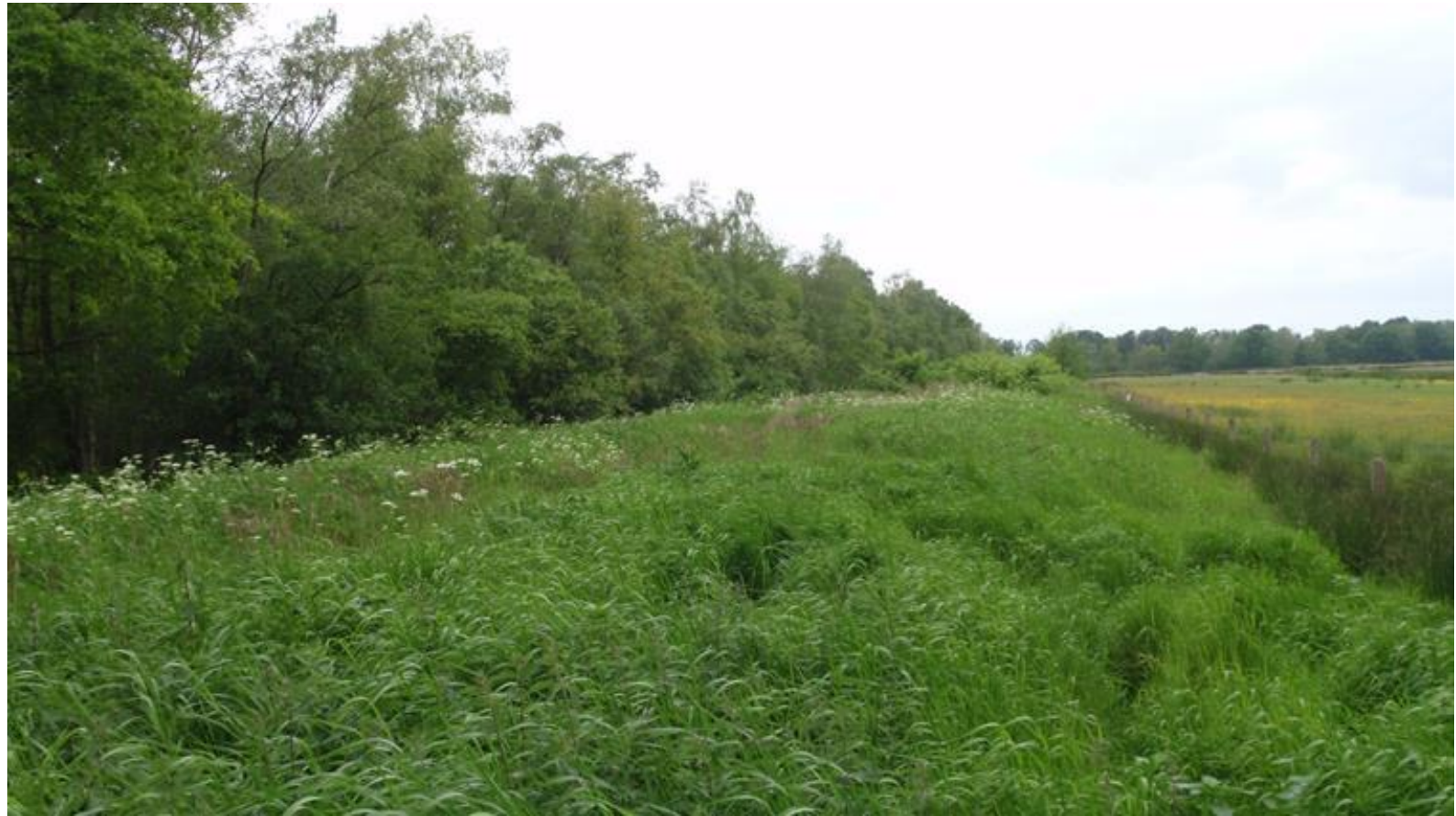


Centrum dorp in buurt van Sphagnumweg.
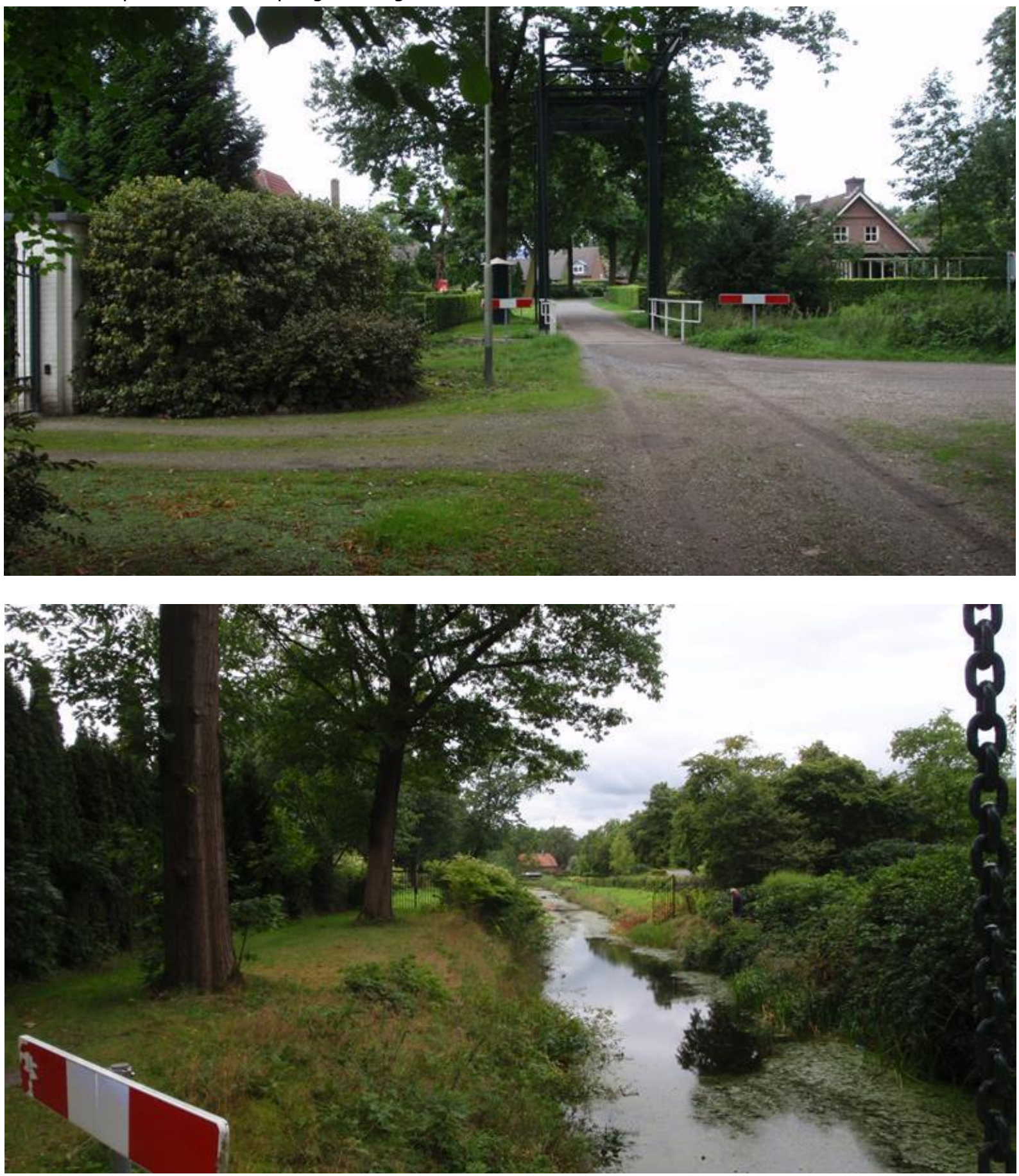